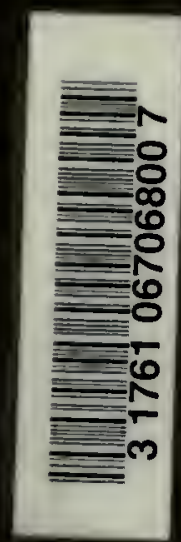

UNIV.OF Jorenino LIBRARY 



AUSTRALASIAN ANTARCTIC EXPEDITION

$1911-14$.

UNDER THE LEADERSHIP OF SIR DOUGLAS MAWSON, D.SC, B.E.

SCIENTIFIC REPORTS.

SERIES C.-ZOOLOGY AND BOTANY.

VOL. VI. PART 3.

\section{POLYCHETA.}

BY

W. B. BENHAM. M.A. (OXON.), D.SC. (LOND.), F.R.S., F.N.Z.INST.

WITH SIX PLATES AND A MAP.

PRICE : TWELVE SHILLINGS.

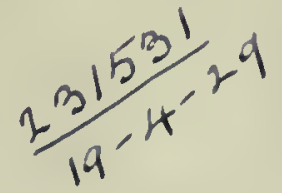

Printed by William Applegate Gullick, Government Printer, Phillip-stteet, Sydney.-igtı. 


\section{Digitized by the Internet Archive in 2007 with funding from Microsoft Corporation}

http://www.archive.org/details/polychaeta00benhuoft 


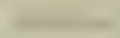
$1+1+10 a, 1=$

$$
\begin{aligned}
& 3+x+1-2=0
\end{aligned}
$$

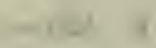




\section{ERRTA.}

P. 7. - The number of Antarctic speeies should be 140 instead of 128 .

P. 18, line 23._- "Phyllococe" should read "Pliyllodoce."

P. 19.-In the list of Macquarie Island specics, "assimils" in penultimate line should read " assimilis."

P. 25, line 4.-For "a symmetrical " read "an asymmetrical."

P. 73, line 13 from foot.-Last words " $\mathrm{S}$. claparedi" should read "O. claparedi."

P. 85, line 5.- "Introduction, p. 10 " should read "p.x."

P. 122.- I did not see proofs of the plates, and unfortunately the letterings of certain figures illustrating the structure of Phyllocomus, and Amythas have becn omitted.

P. 125,_" Dibranchiata Phyllcomus" should rearl "Phyllocomus." 


\section{CONTENTS.}

PAGE.

$\begin{array}{llllllllll}\text { Introduction } & \ldots & \ldots & \ldots & \ldots & \ldots & \ldots & \ldots & \ldots & 5\end{array}$

$\begin{array}{lllllllll}\text { List } \text { of species collected } & \ldots & \ldots & \ldots & \ldots & \ldots & \ldots & 8\end{array}$

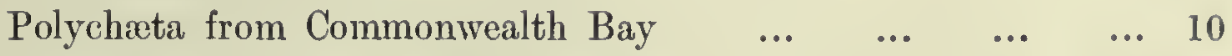

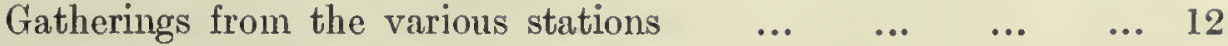

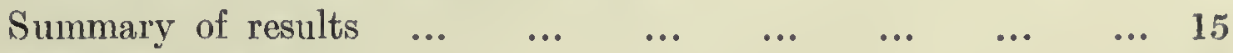

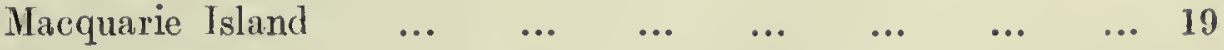

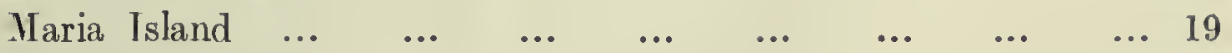

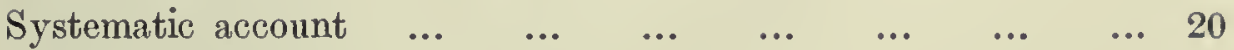

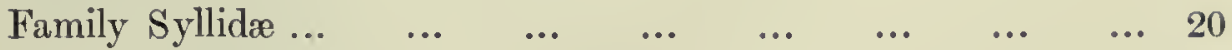

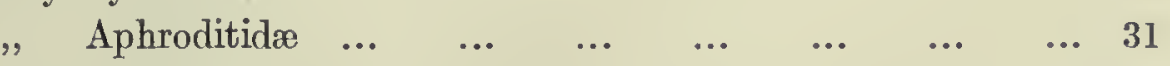

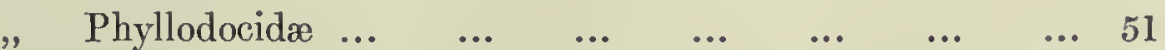

, $\begin{array}{lllllllll}\text { Alciopidæ } & \ldots & \ldots & \ldots & \ldots & \ldots & \ldots & \ldots & 58\end{array}$

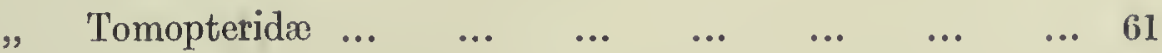

" $\begin{array}{llllllllll} & \text { Nereidæ } & \ldots & \ldots & \ldots & \ldots & \ldots & \ldots & \ldots & 65\end{array}$

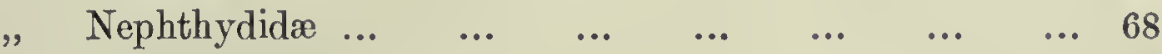

, $\quad \begin{array}{llllllll}\text { Amphinomidæ } & \ldots & \ldots & \ldots & \ldots & \ldots & \ldots & 69\end{array}$

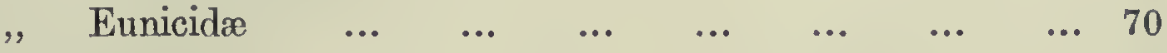

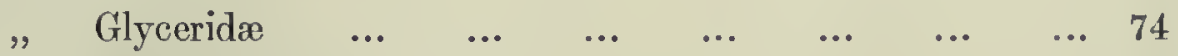

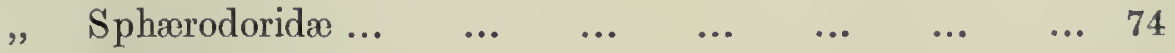

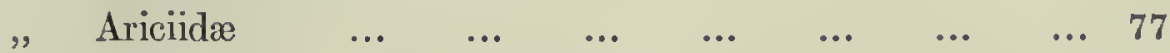

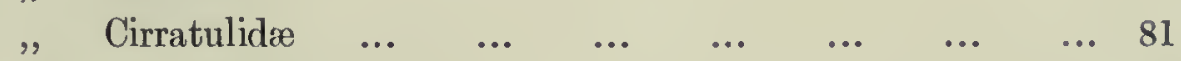

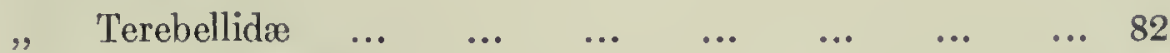

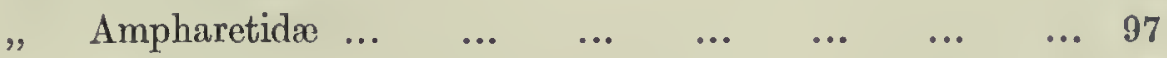

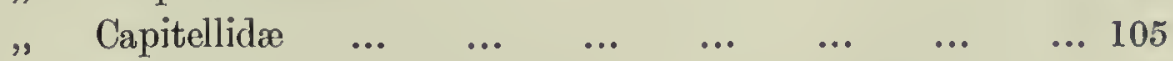

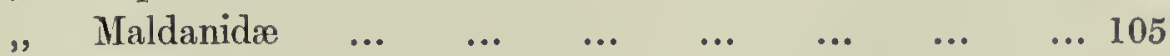

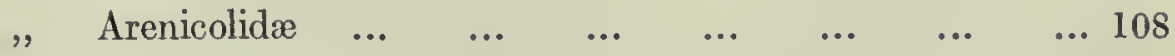

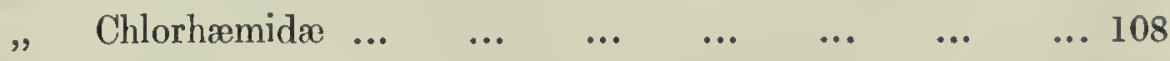

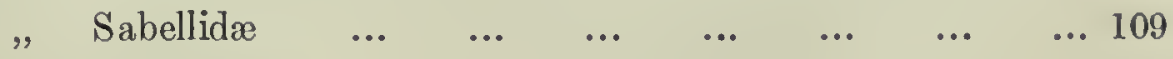

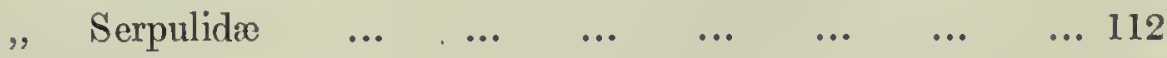

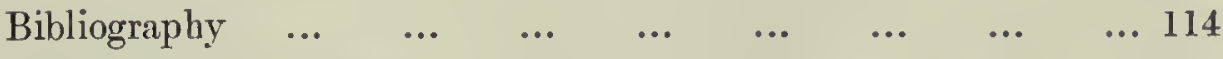

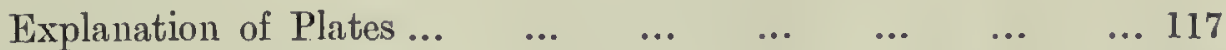

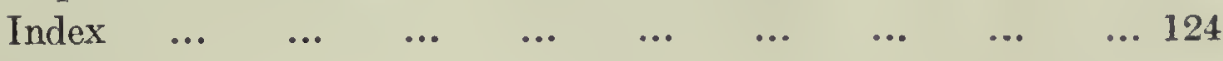

Plates. 



\section{POLYCH ANTA.}

By W. B. Benнам, M.A. (Oxon.), D.Se. (Lond.), H.R.S., F.N.Z.Inst., Professor of Biology, University of Otago, New Zealand.

With Six Plates and a Map.

\section{INTRODUC'IION.}

THe Polychæt fauna of the Antaretic and Sub-antaretie regions is perihaps as well known as that of any other region, with the exception, it may bc, of that of the North Sea and Mediterranean, whieh has been studied intensively by mumero:ss zoologists for nearly a century.

In defining the extent of the Antaretie region I follow Ehlers, who includes not only the shores of the land-mass, but those islands which lic to the sonth of the outermost limit of the drifting sea-ice; thus the islands of South Georgia and Bouvet are included, while the Falkland, Crozet and Kerguelen Islands belong to the Sub-antarctic region.

The varions expeditions to these high sonthern latitudes have brought baek a considerable number of worms, many of which, indeed the majority, are confined to these two regions.

During the voyagcs of the "Engenie" (1851-1853), of the "Challenger" (18731876), of the "Gazelle" (1876), and of the "Valdivia" (1898-1899) more or less extensive areas of the oceans were explored, but the Sub-antaretie region was visited only incidentally. To Kinberg we owe the foundation of our knowledge of the worms of this Notial region since the "Engenie" visited Kerguclen and the Magellan Strait during its voyage. 'Other species were added by Grube in his report, while the aceounts of McIntosh and Ehlers not only extended our knowledge of this region, but for the first time contain deseriptions of worms from the Antarctic Seas; and these ships had been able to explore them to greater depths than had been possible previously.

Later expcditions, on the other hand, visited the edge of the Antarctic land-mass with the express purposc of studying the scientific problems prescnted by that region and these expeditions remained there for many months, so that the natnralists were afforded opportunities of making extensive eollections of the marine animals living in the ice-eovered sea. 
Of these Antarctic expeditions, the "Sonthern Cross" (1898) lad its winter quarters off Cape Adare in the Ross Sca; the "Discovery" (1901-1904), under Captain R. F. Scott, R.N., was lield fast in the ice for two years in McMurdo Bay, South Victoria Land; both these places being to the sonth of New Kealand. The German Southpolar expedition on the "Gauss" (1901-1903) wintered off Kaiser Wilhelm II Land which lies to the south of Kerguclen; while the two French expeditions on the "Frangais" (1903-1905) and on the "Pourquoi Pas?" (1908-1910) explored the lands and islands to the south of America, wintering off Petermann Island.*

In the terms of Sir Clenents Markhan's subdivisions of the Antarctic landmass, the two Euglish expeditions explored and wintered in the "Victoria Quadrant"; the German in the "Enderby," and the French in the "Weddell Quadrant" (see Waite, 1916).

We have consequently collections of Polychæta from the seas extending more than half way round the Antarctic land-mass.

During the voyage of the "Erebus" and "Terror" (1839-1843), under Sir James Clarke Ross, R.N., the Antarctic was visited, but no report on Polychrta was issued. It is probable that the few isolated descriptions of worms from the "Antarctic," published by some of the earlier English Naturalists, such as Baird's Eunice antarctica, were collected by that expedition.

Other expeditions have visited the Antarctic in recent years, but the reports on the collections of Polychæta either have not yet been issued, or certain families only have received attention. The Belgian expedition (1897-1899) conveyed by the "Belgica," lias apparently published no report on the group. Of those obtained by the Swedish expedition (1901-1903) the family Maldanidx has been dealt with by Arwidsson. Of the Polychætes gathered by the "Scotia" during the Scottish National Expedition (1902-1904) the families Serpulidx and Sabellidx have been reported upon by Helen Pixell; and the Nereidx by L. N. G. Ramsay; while the British Antarctic expedition (1907-1909), under Sir E. Shackletoll, has not yet issued any report on the group.

Although these various expeditions collected chiefly from the Antarctic and Sub-antarctic regions, yet most of them took any opportunity that was presented of gathering animals elsewhere; but with these we arc not concerned.

In order to compare the results obtained by the "Aurora" with those of previous expeditions, it may be convenient to tabulate the number of species collected, and the number of new species recorded from the Antarctic seas.

- The French expeditions obtained Annelids from various localities off the South Shetland group (e.g., ile Deception and Admiralty Bay), and from various stations near the islands lying to the north, and, chiefly, to the south of Graham Isud, eg, Terre Alexandre, Terre Falliére, ile Booth Wandel (wherc Port Chareot is situated), ile Wiencke (Port Trkroy), ile Petermann (at Port Circoncision), ile Anvers (where is Biscoe Bay), \&c. It will be sufficient to refer to these ities in gener2! by the tcrm "South American Antartis," m-tacr than repeat cvery locality when listing distribution. 
Antarctic Polycheta.

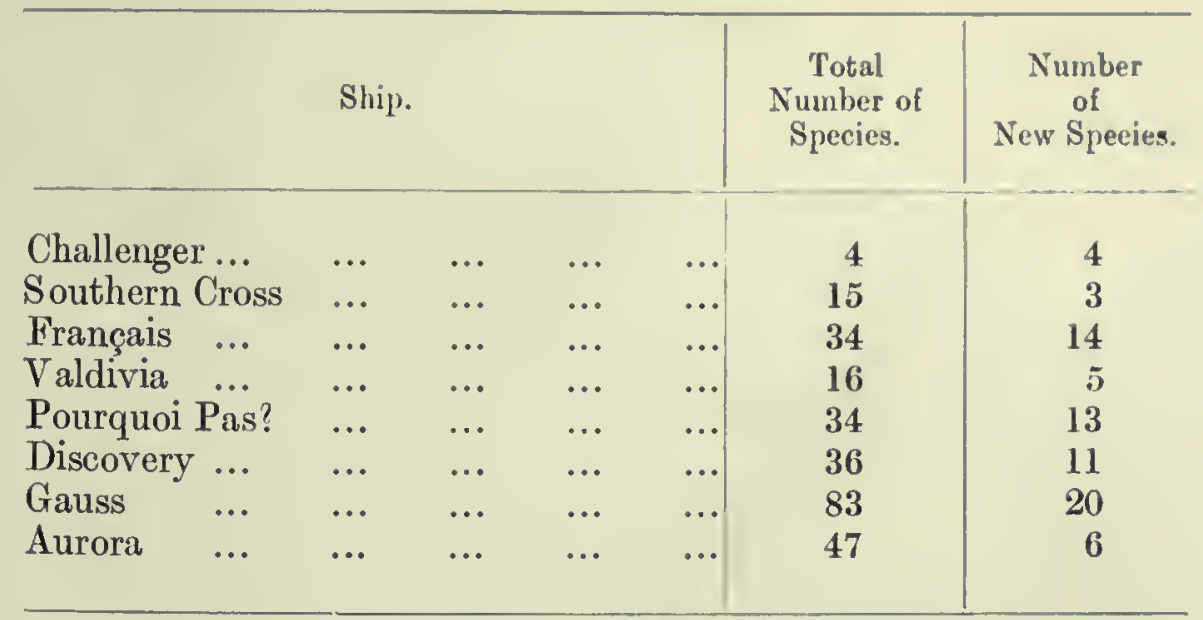

I have estimated from these various reports, including the present one, that about 128 species of Polychæta are known from the Antarctic seas.

Of these the families most abundantly represented are :-

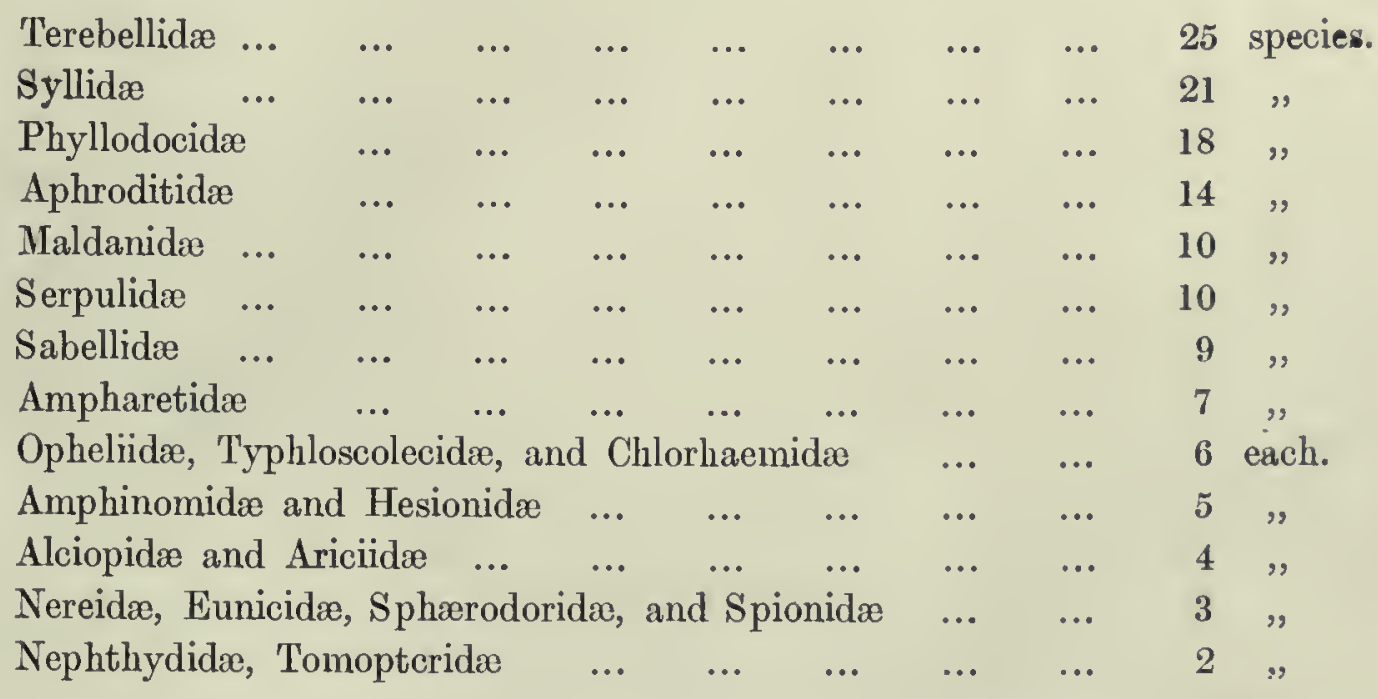

Glyceridæ, Capitellidæ, Scalibregmidæ, Amuocharidæ and Cirratulidæ are each represented by one species only.

The winter quarters of the "Aurora" were in Commonwealth Bay, Adelie Land, to the south of Australia; and it was here that most of the collecting was carried out. A small party had been left on Macquarie Island in connection with the Meteorological and Wireless Station, and during the two years spent here a number of Polychrtes and Oligochætes were gathered around the shore.

A few worms were also obtained by trawling off Maria Island, Tasmania, under the supervision of Professor T. T. Flynn, of the University of Tasmania, who had aceom. panied the "Aurora" on one of her trips to the Macquaries. 


\section{LIST OF SPECIFS COLLECTED.}

PAGE.

Family Syllide-

$\begin{array}{lllllll}\text { Syllis closterobranchia Sehmarda } & \ldots & \ldots & \ldots & \ldots & \ldots & 20\end{array}$

$\begin{array}{llllllll}\text { Syllis brachycola Ehlers } & \ldots & \ldots & \ldots & \ldots & \ldots & \ldots & 22\end{array}$

$\begin{array}{llllllll}\text { Pionosyllis comosa } \text { Gravier } & \ldots & \ldots & \ldots & \ldots & \ldots & \ldots & 22\end{array}$

$\begin{array}{lllllll}\text { Trypanosyllis gigantea MeIntosh } & \ldots & \ldots & \ldots & \ldots & \ldots & 23\end{array}$

Splucrosyllis mointoshi Ehlers ...

$\begin{array}{lllllll}\text { Exogone anomalochoeta } \text { sp. nov. } & \ldots & \ldots & \ldots & \ldots & \ldots & 24\end{array}$

$\begin{array}{llllllll}\text { Autolytus charcoti Gravier } & \ldots & \ldots & \ldots & \ldots & \ldots & \ldots & 27\end{array}$

Family Aphroditidæ--

Sub-family Hermioninæ-

$\begin{array}{llllllll}\text { Latmonice producta Grube } & \ldots & \ldots & \ldots & \ldots & \ldots & \ldots & 31\end{array}$

$\begin{array}{lllll}\text { Latmonice producta var. benthaliana McIntosh } & \ldots & \ldots & \ldots & 31\end{array}$

Sub-family Polynoinæ-

$\begin{array}{llllllll}\text { Enipo rhombigera Ehlers } & \ldots & \ldots & \ldots & \ldots & \ldots & \ldots & 32\end{array}$

$\begin{array}{llllllll}\text { Hololepidella flynni sp. nov. } & \ldots & \ldots & \ldots & \ldots & \ldots & \ldots & 33\end{array}$

$\begin{array}{lllllll}\text { Physalidonotus rugosus Benham } & \ldots & \ldots & \ldots & \ldots & \ldots & 35\end{array}$

$\begin{array}{llllllll}\text { Harmothos spinosa Kinberg } & \ldots & \ldots & \ldots & \ldots & \ldots & \ldots & 35\end{array}$

$\begin{array}{llllllll}\text { Harmothoe tuberosa Ehlers } & \ldots & \ldots & \ldots & \ldots & \ldots & \ldots & 39\end{array}$

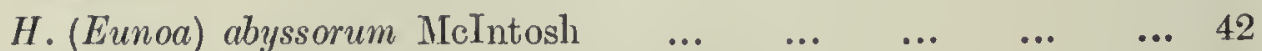

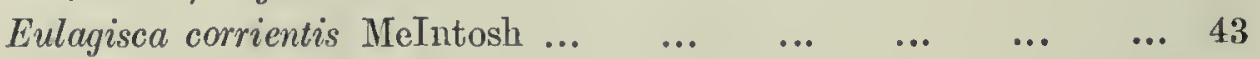

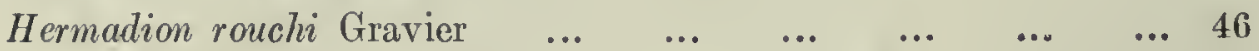

Family Phyllodocidæ-

Sub-family Phyllodocinx-

$\begin{array}{lllllll}\text { Phyllodoce madeirensis Langerhans } & \ldots & \ldots & \ldots & \ldots & \ldots & 51\end{array}$

$\begin{array}{llllllll}\text { Eulalia magalhaensis Kinberg } \ldots & \ldots & \ldots & \ldots & \ldots & \ldots & 52\end{array}$

$\begin{array}{llllllll}\text { Eulalia charcoti Gravier } & \ldots & \ldots & \ldots & \ldots & \ldots & \ldots & 52\end{array}$

$\begin{array}{llllllll}\text { Pterocirrus mcleani sp. nov. } & \ldots & \ldots & \ldots & \ldots & \ldots & \ldots & 55\end{array}$

$\begin{array}{llllllll}\text { Pterocirrus hunteri sp. nov. } & \ldots & \ldots & \ldots & \ldots & \ldots & \ldots & 53\end{array}$

$\begin{array}{lllllllll}\text { Ettone reyi Gravier } & \ldots & \ldots & \ldots & \ldots & \ldots & \ldots & \ldots & 56\end{array}$

Sub-family Lopadorhyehinæ-

$\begin{array}{lllllllll}\text { Pelagobia viguieri Gravier } & \ldots & \ldots & \ldots & \ldots & \ldots & \ldots & 57\end{array}$

Family Aleiopidæ-

$\begin{array}{llllllll}\text { Vanadis antarctica McIntosh } & \ldots & \ldots & \ldots & \ldots & \ldots & \ldots & 58\end{array}$

Family Tomopteridx-

$\begin{array}{lllllll}\text { Tomopteris carpenteri Quatrefages } & \ldots & \ldots & \ldots & \ldots & \ldots & 61\end{array}$

$\begin{array}{lllllll}\text { T. septentrionalis Quatrefages. ... } & \ldots & \ldots & \ldots & \ldots & \ldots & 64\end{array}$ 
Family Nereidx-

PAGF.

$\begin{array}{llllllll}\text { Nereis loxechini Kinberg } & \ldots & \ldots & \ldots & \ldots & \ldots & \ldots & 65\end{array}$

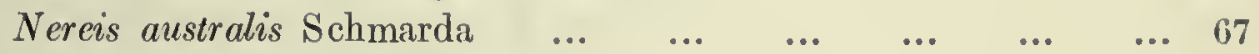

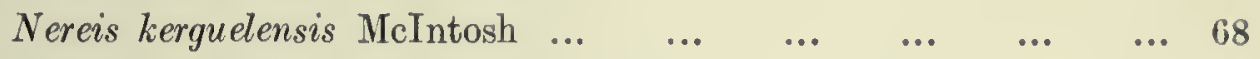

Family Nephthydidx-

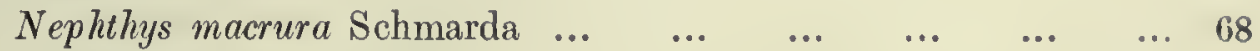

Family Amphinomidæ-

$\begin{array}{llllllll}\text { Eurythoe complanata Pallas } & \ldots & \ldots & \ldots & \ldots & \ldots & \ldots & 69\end{array}$

Family Eunicidæ-

Sub-family Eunicinæ-

$\begin{array}{llllllll}\text { Eunice tentaculata Quatrefages... } & \ldots & \ldots & \ldots & \ldots & \ldots & 70\end{array}$

Sub-family Lumbriconereinæ-

$\begin{array}{lllllll}\text { Lumbriconereis magalhaensis Kinberg... } & \ldots & \ldots & \ldots & \ldots & 70\end{array}$

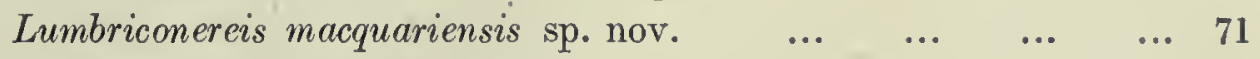

$\begin{array}{llllllll}\text { Ophryotrocha claparedi Studer } & \ldots & \ldots & \ldots & \ldots & \ldots & 72\end{array}$

Family Glyceridm-

$\begin{array}{lllllllll}\text { Glycera capitata } \text { Oersted } & \ldots & \ldots & \ldots & \ldots & \ldots & \ldots & 74\end{array}$

Family Sphærodoridæ-

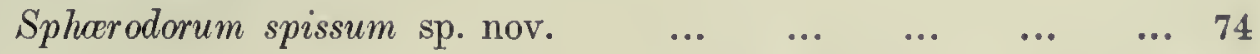

Family Ariciidæ- .

$\begin{array}{llllllll}\text { Aricia marginata Ehlers } \quad \ldots & \ldots & \ldots & \ldots & \ldots & \ldots & 77\end{array}$

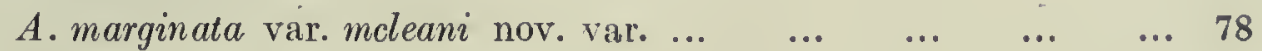

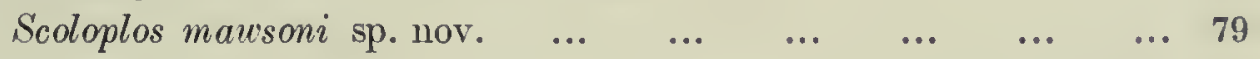

Family Cirratulidæ-

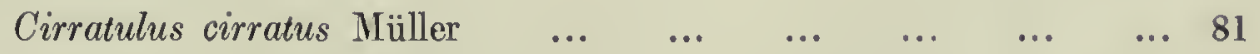

Family 'Terebellidæ-

Sub-family Amphitritinæ-

$\begin{array}{llllllll}\text { Amphitrite kerguelensis McIntosh } & \ldots & \ldots & \ldots & \ldots & \ldots & 82\end{array}$

$\begin{array}{lllllllll}\text { Terebella ehlersi Gravier } \quad \ldots & \ldots & \ldots & \ldots & \ldots & \ldots & 82\end{array}$

$\begin{array}{llllllll}\text { Terebella vayssieri Gravier } & \ldots & \ldots & \ldots & \ldots & \ldots & \ldots & 83\end{array}$

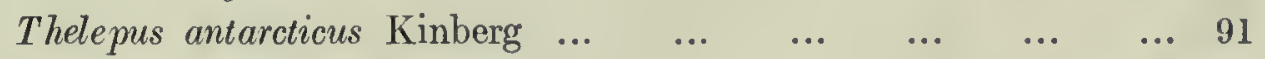

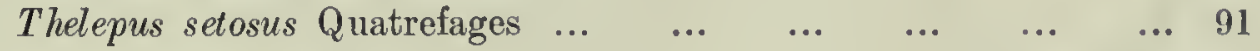

$\begin{array}{lllllllll}\text { Lecena arenilega Ehlers ... } & \ldots & \ldots & \ldots & \ldots & \ldots & \ldots & 89\end{array}$

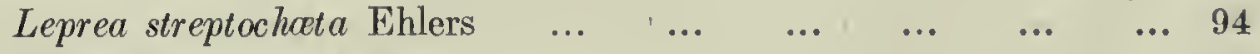

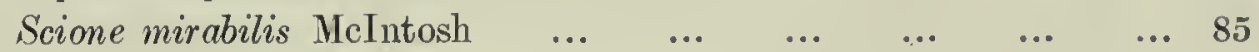

Sub-family Polycirrinæ-

$\begin{array}{llllllll}\text { Polycirrus hamiltoni sp. nov. } & \ldots & \ldots & \ldots & \ldots & \ldots & \ldots & 94\end{array}$

$\begin{array}{llllllll}\text { Ereutho antarctica Willey } & \ldots & \ldots & \ldots & \ldots & \ldots & \ldots & 95\end{array}$ 
PAGE.

Family Ampharetidx-

$\begin{array}{lllllll}\text { Phyllocomus dibranchiata sp. nov. } & \ldots & \ldots & \ldots & \ldots & \ldots & 97\end{array}$

$\begin{array}{llllll}\text { Amythas membranifera gen. sp. nov. ... } & \ldots & \ldots & \ldots & \ldots & 102\end{array}$

Family Capitellidx-

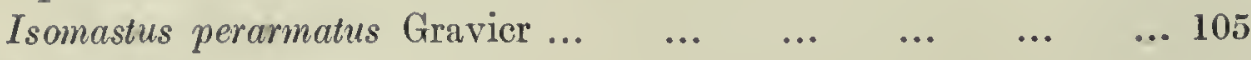

Family Maldanidæ-

$\begin{array}{lllllll}\text { Rhodine intermedia Arwidsson } & \ldots & \ldots & \ldots & \ldots & \ldots & 105\end{array}$

$\begin{array}{llllllll}\text { Isocirrus yungi Gravier } & \ldots & \ldots & \ldots & \ldots & \ldots & \ldots & 106\end{array}$

Family Arenicolidæ-

$\begin{array}{llllll}\text { Arenicola assimilis var. affinis Ashworth } & \ldots & \ldots & \ldots & \ldots & 108\end{array}$

Family Chlorhæmidæ-

$\begin{array}{llllllll}\text { Flabelligera mundata Gravier } & \ldots & \ldots & \ldots & \ldots & \ldots & \ldots & 108\end{array}$

Family Sabellidæ-

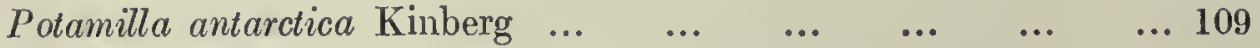

Family Serpulidæ-

$\begin{array}{llllll}\text { Serpula vermicularis var. narconensis } & \text { Baird } & \ldots & \ldots & \ldots & 112\end{array}$

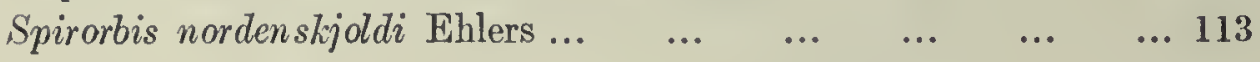

\section{II.-POLYCHETA FROM COMMONWEALTH BAY.}

I have been supplied by Mr. J. G. Hunter, Biologist to the expedition, with the following information as to the collection of the worms :-

" During the greater part of the year 1912 dredgings were carried out in a small boat-harbour close to winter quarters. The depth varied from 2-5 fathoms; the bottom for the most part muddy, and dredgings yielded a considerable number of Amulates, which form the chief constituent of the fauna of these shallow waters.

"Dredging in deeper water was prevented by the abnormal weather conditions that prevailed. In these latitudes the sea generally freezes over during the winter, and then by digging channels in the ice a dredge can be lowèred. The violence of the winds at Adelic Land, however, prevented the sea from freezing, excepting at the beginning of Septcmbcr, 1912, when, during a calm lasting for several days, the sea froze sufficiently to allow of dredging operations. And so, on the 3rd and 4th of that month, rich hauls were made in depths from 15-30 fathoms.

"While the 'Aurora' was anchored in Commonwealth Bay, several dredgings wcre made with a small hand-dredge - $(a)$ on 20th January, 1913, in 15-20 fathoms ; (b) on 14th Deccmber of the same ycar, in 45-50 fathoms; and $(c)$ on 21 st of the month, in $55-60$ fathoms. 
"During the summer cruise, Mr. J. G. Hunter, assisted by Mr. H. Hamilton, a number of dredgings were taken in deeper waters, the 'Aurora' being specially fitted for this purpose."

In addition, some tow-netting was done in the bay.

The list of stations and the details of the hauls follow. A total of forty-seven species were obtained at these stations, the majority of which, as would be expected, are already known; but I have found it necessary to establish two new species of Phyllodocids of the sub-genus Pterocirrus, namely, Eulalia (Pterocirnus) hunteri and Eulalia (Pterocirrus) moleani: as well as a new species of Exogone, and of Scoloplos, and a new variety of Aricia marginata, in which the arrangement of the spines in the anterior segments presents a condition recalling that occurring in $A$. ohlini Ehlers.

Further, a new species of the Ampharetid Phyllocomus, hitherto represented only by $P$. crocea Grube, exhibits a form of gill unique in the family. While a new genus in the same family seems needed for a species which possesses an entirely novel kind of tentacular apparatus in the form of a folded and introversible membrane in place of the usual filamentous tentacles. I have named this worm Amythas membranifera.

The collection is also of interest in that it contains as many as three specimens of the rare Nereis loxechini Kinberg, of which only three individuals have hitherto been recorded.

Tomopteris carpenteri Quatrefages, so long unrecognised, is also represented, and is fully described; and a northern species, T. septentrionalis Quatrefages, is included in the collection. Certain other species hitherto found only outside the Antarctic region must now be included in that fauna, namely, Eulagisca corrientis McIntosh, and Eunoa abyssorum McIntosh.

In the total number of species submitted to me, and therefore presumably collected by the "Aurora," the present compares favourably with the number taken by previous expeditions, other than the "Gauss," which was an extremely rich collection.

One cannot help being struck with the enormous quantity of some of the species living at the sea-bottom in these cold seas. Thus in this collection I find in a single haul more than 100 individuals of Thelepus antarcticus; again, sixty-five individuals of Harmothoe spinosa were obtained at one haul; and of Potamilla antarctica as many as forty were brought up in the dredge at one spot.

This abundance of individuals may be due in part to the scarcity of enemies and in part to the fact that the conditions, although so apparently severe, must in reality be very favourable for their existence. 


\section{GATHERINGS FROM THE VARIOUS STATIONS.}

\section{Adelie Land.}

Boat Harbour, Commonwealth Bay, Adelie Land. Lat. $67^{\circ}$ South. Long. $142^{\circ} 36^{\prime}$ Fast.

A. -2-5 fathoms. Collected by Dr. A. I. McLean :-

Syllis closterobranchia.

Pionosyllis comosa.

Spharosyllis mointoshi.

Exogone anomalochata.

Autolytus charcoti.

Harmothoe spinosa.

Harmothoe tuberosa.

Nephthys macrura.

Ophryotrocha claparedi.

Aricia marginata.

Scoloplos mawsoni.

Cirratulus cirratus.

Terebella ehlersi.

Terebella vayssieri.

Ereutho antarctica.

Isomastus perarmatus.

Rhodine intermedia.

Spirorbis nordenskioldi.

B.-Boat Harbour, 25-30 fathoms (3rd and 4th September, 1912) :--

Harmotho tuberosa.

Phyllodoce madeirensis.

Nephthys macrura.

Aricia marginata var. mcleani.

Terebella ehlersi.

Thelepus antarcticus.

Potamilla antarctica.

Serpula vermicularis var. narconenis.

C.-Commonwealth Bay, 15-20 fathoms (20th January, 1913) :-

Syllis closterobranchia.

Harmothoe spinosa.

Harmothoe tuberosa.

Terebella ehlersi.

Thelepus antarcticus.

Ieana arenileja. 
D.-Commonwealth Bay, 45-50 fathoms (14th December, 1913):-

Syllis closterobranchia.

Tryanosyllis gigantea.

Harmothoe spinosa.

Harmothoe tuberosa.

Enipo rhombigera.

Phyllodoce madeirensis.

Terebella ehlersi.

E.-Commonwealth Bay, 55-60 fathoms (21st December, 1913):-

Harmothoe spinosa.

Harmothoe tuberosa.

Enipo rhombigera.

Terebella ehlersi.

Summer Cruise, 1913-1914.

Station 1.- Lat. $66^{\circ} 50^{\prime}$ South. Long. $142^{\circ} 6^{\prime}$ East. Depth, 350-400 fathoms. . Temperature, $-1.84^{\circ}$ Cent. Bottom, thick ooze. (22nd December, 1913.).

Trypanosyllis gigantea.

Harmothoe spinosa.

II armotho tuberosa.

Hermadion rouchi.

Enipo rhombigera.

Pterocirrus mcleani.

Serpula vermicularis var. narconensis.

Station 2.-Lat. $66^{\circ} 55^{\prime}$ South. Long. $145^{\circ} 21^{\prime}$ East. Depth, 318 fathoms. Temperature, $-1.8^{\circ}$ Cent. Bottom, ooze: (28th December, 1913.)

Trypanosyllis gigantea.

Enipo rhombigera.

Eulatia charcoti.

Nereis loxechini.

Glycera capitata.

- Aricia marginata.

Scione mirabilis.

Serpula vermicularis var. narconensis.

Station 3.-Lat. $66^{\circ} 32^{\prime}$ South. Long. $141^{\circ} 39^{\prime}$ East. Depth, 157 fathoms. Temperature, $-1 \cdot 62^{\circ}$ Cent. Bottom, ooze. (31st December, 1913.)

Syllis closterobranchia.

Latmonice producta.

Harmothoe spinosa.

Harmothoe tuberosa.

Enipo rhombigera. 
Eulalia charcoti.

Nereis loxechini.

Nephthys macmura.

I cocirmus yungi.

Amphitrite kerguelensis.

Phyllocomus dibranchiata.

Potamilla antarctica.

Stations 4, 5 and 6 yielded no Polychætes.

Station 7.-Lat. $65^{\circ} 42^{\prime}$ South. Long. $92^{\circ} 10^{\prime}$ East. Depth, 60 fathoms. Temperature not taken. Bottom, red Algæ, and a few small rocks, and various forms of animal life; no ooze. (1st January, 1914.)

$V$ anadis antarctica.

Potamilla antarctica.

Station 8.-Lat. $66^{\circ} 8^{\prime}$ South. Long. 94 ${ }^{\circ} 7^{\prime}$ East. Depth, 120 fathoms. Temperature not taken. Bottom, small granitic rocks; no ooze. (27th January, 1914.)

Harmothoe spinosa.

Harmothoe tuberosa.

Eulagisca corrientis.

Enipo rhombigera.

Phyllodoce madeirensis.

Eulalia charcoti.

Scione mirabitis.

Potamilla antarctica.

Serpula vermicularis var. narconensis.

Station 9.-Lat. $65^{\circ} 20^{\prime}$ South. Long. 95 $27^{\prime}$ East. Depth, 240 fathoms. Temperature, $+1 \cdot 38^{\circ}$ Cent. Bottom, granitic pebbles, with small amount of ooze. (28th January, 1914.)

Serpula vermicularis var. narconensis.

Station 10.-Lat. $65^{\circ} 6^{\prime}$ South. Long. $96^{\circ} 13^{\prime}$ East. Depth; 325 fathoms. 'Temperature, $-1 \cdot 65^{\circ}$ Cent. Bottom, ooze. (29th January, 1914.)

Harmothoe spinosa.

$H$. (Eunoa) abyssorum.

Enipo rhombigera.

Hermadion rouchi.

Nereis loxechini.

Lumbriconereis magalharnsis.

Flabelligera mundata.

Amythas membranifera.

Serpula vermicularis var. narconensis. 
Station 11.-Lat. 64 $44^{\prime}$ South. Long. $97^{\circ} 28^{\prime}$ East. Depth, 358 fathoms. Temperature not taken. Bottom, ooze. (31st January, 1914.)

Iatmonice producta.

Harmothoe (Eunoa) abyssorum.

Station 12.-Lat. $64^{\circ} 32^{\prime}$ South. Long. $97^{\circ} 20^{\prime}$ East. Depth, 110 fathoms. 'T'em. perature not taken. Bottom, rock. (31st January, 1914.)

Harmothoe spinosa.

H. (Eunoa) abyssorum.

Hermadion rouchi.

Enipo rhombigera.

Eulalia charcoti.

Pterocirms hunteri.

Nephthys macrura.

Glycera capitata.

Flabelligera mundata.

Scione mirabilis.

Potamilla antarctica.

Station 13.-Depth, 1,800 fathoms. No worms were taken.

\section{SuRface 'Tow-NetTing.}

Boat Harbour.-By Dr. A. L. McLean.

Autolytus charcoti (1912).

Vanadis antarctica (1913).

On edge of pack-ice.

Pelagobia viguieri, in 45-100 fathoms. (6th and 10th January, 1914.)

Tomopteris septentrionalis, in 45-100 fathoms. (6th and 10th January, 1914.)

Tomopteris carpenteri, in 30-45 fathoms. (January, 1914.)

\section{SUMmary of Results.}

It seems unnecessary to give tabular statements of the faunistic relations of these Antarctic species, for this has been done by Gravier, and in greater elaboration by Ehlers in his magnificent and exhaustive report of the German expedition (1913).

But a summary of the results in regard to each of the families represented in this collection may be useful.

\section{Family SYLLID㤅.}

Twenty-one species of this family have been recorded from the Antarctic region, but the present collection contains only five of them. Owing, no doubt, to their small size, these worms are likely to be overlooked unless great care be taken in sorting out the material. 
Of the six species in the collection, Exogone anomalochœta is new; which ivith Autolytus charcoti and Pion syllis comosa is limited, so far as is known, to the region. The atokous and both sexes in the epitokous phases of Autolytus were met with. Spharosyllis meintoshi passes northwards beyond this region to Kerguelen and South Georgia. Trypanosyllis gigantea occurs in the Magellan area, and Syllis closterobranchia passes beyond the Sub-antarctic region into the Southern Temperate zone to West Africa and to New Zealand.

\section{Family APHRODITIDAE.}

Hitherto twelve species have been noted as occurring in the Antarctic, of which five are found in the present collection, and two additional species are to be recorded as entering the region. Of these seven species Enipo rhombigera, Hermadion rouchi and Harmothoe tuberosa are confined to the region. H. spinosa, a very common worm here, is also met with in the sub-antarctic area. Latmonice producta is the most widely distributed, passing northwards in the Atlantic to the West Coast of Ireland, and up through the Pacific to the Japan coast.

The two additions to the Antarctic famna are Eunoa abyssorum, which is known elscwhere only in deep water to the south east of Australia ; and Eulagisca corrientis. ranges up the east coast of South America as far as Buenos Ayres.

\section{Family PHYLLODOCID㤅:}

This family is represented in the region by sixteen species, three of which occur in the "Aurora" gatherings. Of these Eulalia charcoti, Eicone regi, and Pelagobia viguieri are confined to the Antarctic; and two new species have to be added to the list, namely, Pterocirrus Mclcani, and Pt. hunteri. The fifth is Phyllococe madeirensis, whose specific name would scarcely lead us to expect it in these waters, yet it has àlready been recorded from Cape Adare as. well as from South Georgia and Juan Fernandez. Fauvel has suggested, in explanation of the wide distribution of this and some other species, that it descends in the equatorial regions to great depths, and passing southwards rcappcars in the colder waters at less depths.

\section{Family ALCIOPIDÆ.}

The only species observed is Vanadis ant rctica, which has a world-wide range through the oceans, as one would expect from its pelagic habit.

\section{Family TOMOPTERIDA.}

The only species which have been collected in Antarctic scas are the two species included in the present report, namely, $T$. carpenteri, the history of which will be found detailed in the systcmatic portion, and $T$. septentrionalis, which has recently necn recorded by Gravier from the Weddell Quadrant. 


\section{Family NEREIDA.}

As in other expeditions, this family was found but sparsely in the Antarctic; indeed, until 1908, the only species that had been net with was $N$. loxechini, which Kinberg had originally described from the Magellan Strait, but which in recent years has been recorded from the deep water to the east of Island of St. Paul, and from the winter quarters of the "Gauss." But Ehlers found amongst the "Valdivia" worms Nereis uncinata from near Bouvet Island. The "Aurora" did not meet with it.

\section{Family NEPHTHYDIDA.}

In addition to $N$. macrura, which is a Sub-antarctic form entering the Antaretic region, $N$. abranchiata, has been recorded from the region by Ehlers (1913).

\section{Family EUNICIDÆ.}

The Eunicids scarcely enter the Antarctic, for only two species have ever been recorded, both of which are included in the present collection. Iumbriconereis magalhacnsis is a typically Sub-antarctic form, and only one specimen was gathered in Commonwealth Bay. The small pelagic Ophryotrocha claparedi was however extremely abundant in Boat Harbour; it has already been gathered elsewhere, though recorded under the title of Paractius notialis.

\section{Family GLYCERID A.}

Glycera capitata, originally described from the European seas, is the only member of the family that appears to enter the region under consideration. It has been met with by each of the expeditions.

\section{Family ARICIID正.}

Hitherto only three species belonging to the family have been described from the Antarctic region. One of these, Aricia marginata, is included in the present collection. A new species, Scoloplos mawsoni, is necessary for a worm that differs from S. kerguelensis, which has been recorded by the French Fxpedition, but which is characteristically a Sub-antarctic form.

\section{Family CTRRATULID s.}

The Cirratulids are also very rare in the region; only one species has been definitely determined, though Ehlers found certain worms which he names generically without giving specific names to them. This sole species is the European Cirratulus cirratus, hitherto known from the Magellan Strait and elsewhere in the south under Ehlers's title, Promenia fulgida, which Fauvel has shown to be a nomen nudun.

\section{Family 'TEREBELLIDȦ.}

The Antarctic is a favourable habitat for members of the family, as each expedition adds one or more to the species already known. Of the twenty-four that have been recorded the "Aurora" obtained seven off Adelie Land. Of these, three 
appear to be confined to the Antarctic region, namely, Terebella ehlersi, T. vayssieri, and Leana arenilega. The others cnter the sub-antarctic region at Kerguelen and Tierra del Fuego, \&c., while the seventh Scione mirabilis (which, as I show, includes S. spinifera Ehlers) travels up both coasts of South America into the sonthern temperate zone.

\section{Family AMPHARETIDE.}

Six species of this family have been gathered by previous expeditions within this area; the present report contains an account of only two species, both of them new, as I have mentioned earlier in the memoir. These are Phyllocomus dibranchiata and Amythas (gen. nov.) membranifera.

\section{Family CAPITELLIDA.}

It has been stated that this family does not enter the Antarctic region, but Gravier has recorded one species, Isomastus perarmatus from the Weddell Quadrant, and this has also been obtained by the "Aurora."

\section{Family MALDANIDE.}

The Swedish expedition has added materially to our knowledge of the family, as it exists in this region so that seven well characterised species and some varieties are known, as well as threc nnspecified forms recorded by Ehlers. The "Aurora" gathered two of the species, both of which are confined to this region, namely, Rhodine intermedia (hitherto confused with the northern $R$. loveni) and Isocirmus yungi, originally. discovered at Petermann Island.

\section{Family CHLORHAMIDA.}

Of the six species of Flabelligera reported from the Antarctic only one is included in this collection $(F$. mundata), which is wide-spread round the sonthern land-mass. The only other member of the family that has been mentioned is Trophonia kerguelarum Grube, as having been obtained by the "Discovery" at winter quarters, but no reference to this locality is made in Ehlers in his later works, though it is sub-antarctic in its distribution.

\section{Family SABELLID瓜.}

Nine species have been recorded from this region, of which four are quite small and have been obtaincd only by the "Gauss." The only species collected by the "Aurora" is Potamilla antarctica, which occurs in considcrable numbers, and somctimes attains a large size. It also enters the Sub-antarctic region.

\section{Family SERPULIDE.}

Two of the ten species known to occur in the Antarctic are contained in this collection-the widely distributed Serpula vermicularis and Spirorbis nordenskjoldi. 


\section{Macquarie Island.}

This island has not hitherto been explored for Polychreta, lut thanks to the industry and care of Mr. H. Hamilton during the nearly two years lie sojourned here, I ean put on reeord fifteen speeies of which three are new: Lumbriconereis macquariensis, Sphœrodorum spissum and Polycirrus hamiltoni. All the other speeies are typically sub-antaretie in eharacter, and have been recorded either from the southern outliers of New Zealand or from the Kerguelen or Falkland Islands. They were all eolleeted in rock pools or under stones or rocks along the shore.

Syllis closterobranchia.

Syllis brachycola.

Exogone anomalochoeta.

Eulalia magalhaensis.

Nereis kerguelensis.

Nereis australis ( = magalhatnsis).

Iumbriconereis magalhaensis.

Lumbriconereis macquariensis.

Sphorodorum spissum.

Cirratulus cirratus.

Thelepus setosus.

Leprea streptochata.

Polycirrus hamiltoni.

Arenicola assimils var. affinis.

Potamilla antarctica (small forms).

3. Maria Island, Tasmania.

Five speeies were obtained in the two trawls put down by Professor Flynn. Of these one is new, and belongs to a Polynoid genus, Hololepidella, established by Willey for a Ceylon speeies. Two of the other speeies obtained have already been reported from the neighbourhood; the remaining couple are widely distributed.

Hololepidella Aynni (from 1,300 fathoms).

Physalidonotus rugosus (from 65 fathoms).

Latmonice producta var. benthaliana (from 1,300 fathons).

Eunice tentaculata (from 65 fathoms).

Eurythoe complanata. 


\title{
SYSTEMATIC ACCOLNT.
}

\author{
Family SYLLID A.
}

Sub-family SYLLIDEæ.

Genus SyluIS Savigny.

Syluis closterobranchia Schmarda.

Schmarda (1861), p. 72.

Ehlers (1904), p. 19, pl. III, figs. 1-4.

Ehlcrs (1908), p. 45.

Benham (1909), p. 237.

Ehlers (1913), p. 476, pl. XXXI, figs. 1-3 (epitokous phases).

Augcner (1913), p. 200, fig. 23. (I have not seen this.)

Fauvel (1919), p. 354 .

(Plate 5, figs. 1-2.)

It is interesting to find this species, originally regarded as a Sub-antarctic form, occurring off Adelie Land, though it has already been recorded from Kaiser Wilhelm II Land.

Amongst the material I find epitokous phases as well as the atokous. The species seems somewhat variable, judging from the accounts of Ehlers and Fauvel, and my own observations, especially in regard to the shape and length of, and the number of annuli in, the dorsal cirri. I will here refer only to such differences as I have noted, for on the whole the specimens agree with the previous accounts.

The larger individuals in the present collection, which numbers about a score, measure from 20-25 mm. in length, with a width of $1 \mathrm{~mm}$; they contain from 60-100 segments. The breadth of the body is fairly uniform throughout, except for a slight tapering at each end. There are no markings on the dorsal surface.

The prostomium is not quite in agreement with Ehlers's figure, for in the specimens before me it is transversely oval, with the anterior margin produced in the middle line to form a rounded lobe, which is about half the width of the base of the prostomium. Ehlers shows the margin to be a continuous curve. The differcnec is perhaps due to the statc of preservation.

The number of annuli in the cirri has been shown to vary, and Ehlers (1913) has found that in the youngest stages they are not moniliform; and that the annulation increases with age; but I suggest that the differences obscrved in various adults may be in part duc to injury to the tips of the appendages. 
The median prostomial tentacles in the present specimens have 16 anuuli; the laterals 12 ; the dorsal peristomial cirri present 17-18; the ventrals 15 (Fhlers found in a spccimen from the Chatham Islands as many as 21-23 respectively).

'The dorsal cirri have a spindle-shape outline, which is characteristic for the species; the cirri of the anterior six to eight segments are longer than the rest ; their length is greater than the breadth of the body here; the sixth being the longest; it has 20 annuli.

The remainder of the dorsal cirri are fairly uniform in length, but not absolutely so ; though this seems to me due to inequality in contraction.

T'he length of these cirri over the greater part of the body is rather less than the breadth of the body; I find 12-13 annuli in most of them. Ehlers gives 8-11, usually the latter, and in spccimens from the Chatham Islands as many as 21. Fanvel gives 10-15 for Red Sea specimens.

I find (fig. 1) that each parapod is supported by 3 or even 4 acicula, which lie close to one another above the bundle of chæt $x$. 'The end of each aciculum is dilated just below the blunt tip, which is obliquely truncated and projects from the surface. (fig. 2). In some individuals, however, there is no dilatation, and the apex is symmetrically pointed.

The pharynx commences in the 4th chætigcrous segment, as is seen in a specimen. mounted entire in glycerine; it extends back to the tenth segment, where it enters the "stomach" (or "ventriculus") which occupies segments 11-18; the intestine at first passes forwards from this point, and then bends backwards.' It is from the former region that the pair of long cylindrical caca are given off, one of which reaches forwards into the 14 th, the other only as far as the 15 th segment.

\section{Epitokous Phases.}

A male and a female occur amongst the material gathered at Boat Harbour at $3 \frac{1}{2}$ fathoms.

They measure $12 \mathrm{~mm}$. in length, with a width of $1 \mathrm{~mm}$. , and contain about 32 segments. The eyes are large and red. They agree generally with the account and figures given by Ehlers.

I note, however, that four eycs are present in both sexes, one pair on the dorsals the other pair on the ventral surfacc. Ehlers figure shows the male to bo blind.

The prostomial tentacles of the male are longer than in the female, but are not moniliform in either sex.

The male is entire, and possesses two long moniliform anal cirri, longer than the dorsal cirri of that region. In the male the long nodified chæta commence in the third chat gerous seyment, in the female in the sezond.

Ehlers notes that the spawning time occurs in December and January. These were gathered in the former month. 
Localities.-

Commonwealth Bay, Boat Harbour, 2-4 fathoms. Collected by Dr. A. L. McLean. Commonwealth Bay, Station C. 15-20 fathoms; Station D. 45-50 fathoms ; Station 3, 157 fathoms.

Macquarie Island, Rock pools, coll. Mr. Hamilton.

Distribution.-Cape of Good Hope (Schmarda), Angra Pequena, New Kealand, Chatham Islands, Kaisər Wilheln II Land(Ehlers), Campbell Island, Antipodes Islands (Benham), Red Sea (Fauvel*).

\section{Syldis brachycola Ehlers.}

Ehlers (1897), p. 38, pl. II, figs. 46, 47.

Gravier (1906), p. 20, pl. II, fig. 17.

Ehlers (1913), p. 477.

Fauvel (1916), p. 427.

\section{(Plate 5, fig. 3.)}

Several of this species were obtained, and I may note the form of the acicula, of which two or three occur in each parapod. They may be colourless or brown, but have a characteristic extremity. This is a rounded knob quite unlike those of $S$. closterobranchia (fig. 3).

The uppermost chæta, which is capilliform ("Nadel" of Ehlers), does not make its appearance till about the 20th foot, and may even be absent from some of the posterior feet, though whether they are broken or not devcloped I cannot say.

Locality.-

Macquarie Islands. S crapings off kelp.

Distribution.-Magellan, Kerguelcn, South Georgia, Kaiscr Wilhelm II Land (Ehlers), Booth Wandel Island (Gravier), Falkland Islands (Fauvel).

\section{Genus Pionosylis -Malmgren. \\ Pionosyllis comosa Gravier.}

Gravier (1906), p. 15, pl. II, figs. 12, 13.

Gravier (1911), p. 49.

Ehlers (1913), p. 473, pl. XXXII, figs. 1-4.

Several fragments of this Antarctic worm, consisting of the had and some 20 chætigerous segments, were obtained. They measure $25 \mathrm{~mm}$. in length and about $0.5 \mathrm{~mm}$. across. Some are ripe females filled with eggs as far forwards as the proventriculus, but they present no epitolious modifications.

* It may here be noted that Fauvel $(1917, p .193)$ regards the variety of Syllis closterobranchio from the Chatham Islands (Ehlers), a specimen of whieh he has found on tho earst of South Australia, as identica! with $S$. ligalina Grube, 
The freedom of the palps is well seen in those in which the pharynx is protrnded, when they become widely separated, as is shown in Ehlers's figmres.

'The eyes are not so large as he fignres, and I find that the anterior pair are, as usual, larger than the posterior.

The chrtæ of the anterior segments are all alike, but further back the length of the appendix differs in the upper and lower members of the bundle, but not I think to so great an extent as is indicated by Gravier's figures.

\section{Locality.-.-}

Commonwealth Bay.

Distribution.--Port Charcot, Port Circoncision(Gravier), Kaiser Wilhelm II Iand (Ehlers).

\section{Genus Trypanosyluis Claparède.}

Trypanosyllis gigantea McIntosh.

Syllis gigantea McIntosh (1885), p. 193, pl. XXX, figs. 1-3; pl. XXXII!, fig. 4 ; pl. XA, fig. 10 ; pl. XXXIV ${ }_{A}$, fig. 7.

Trypanosyllis gigantea Ehlers (1897), p. 35.

Trypanosyllis gigantea Ehlers (1901), p. 85.

Trypanosyllis gigantea Ehlers (1908), p. 65.

Trypanosyllis gigantea Ehlers (1912), p. 17.

Trypanosyllis gigantea Ellers (1913), p. 475, pl. XXXI, figs. 11-16.

Trypanosyllis gigantea Gravier (1911), p. 52, pl. I, figs. 7, 8.

Trypanosyllis gigantea Fanvel (1917), p. 200, gives further synonymy.

This characteristic Antarctic Syllid is evidently very abundant in Commonwealth Bay, for there are at least twenty individnals in the collection obtained from five stations or perhaps from four, as one of the lots consisting of as many as fourteen specimens is accompanied by no information as to where they were obtained.

Some of the specimens attain to a greater size than even those described by McIntosh, which reached only the length of $60 \mathrm{~mm}$. The largest complete individual in the present collection measures $130 \mathrm{~mm}$., with a diameter of $5 \mathrm{~mm}$. over the body, and $6 \mathrm{~mm}$. across the parapodia. The width of the body is equal to the length of twelve segments, which are thus very short. The body is very much depressed, its height being only $2 \mathrm{~mm}$. McIntosh gives a figure of a transverse section through the pharyngeal region, where the height of the body is increased by the presence of that organ; the worm is in reality much flatter than that figure wonld indicate.

The colour of the preserved specimens is a pale yellow, dorsally and ventrally, becoming brownish anteriorly. One individual is orange brown ventrally, with a yellowish dorsum, and with brown markings along the margins of this surface. 
The tentacles are white; the dorsal cirri are alternately plain white, and white ringed with purplish brown. In some spccimens these white cirri are more closely coiled than the others, and lie close to the body forming a fringe, as it were, along its margin. The purple-ringed cirri, however, are morc loosely coilcd, and they rise above the level of the former, over the back of the worm. The two series of cirri are thus very readily distinguished. All the cirri, like the tentacles, arc moniliform.

Ehlers (1897) states that when alive, the colour of the worms from South Georgia were " a beautiful orange, with white belly ;" those from Magellan Strait were rosyred, with dark brownish-red cirri ; or pale flesh-coloured, with cirri of the same tint; or dark brown. The former plan of colouration seems to agree with those from Commonwealth Bay. He also notes (1911) that in February and March the specics develop swimming bristles, so that presumably they become sexually mature at this period.

Localities.-

Commonwealth Bay, Station D, 45-50 fathoms,

Station 1, 350-400 fathoms,

Station 2, 318 fathoms,

Station 12, 110 fathoms,

*Distribution.-Kerguelen (McIntosh), South Georgia, Magellan Strait, Juan Fernandez, Kaiser Wilhelm II Land, South Victoria Land (Ehlers), Marguerite Bay, Terre Alexandre (Gravier).

Sub-family Exogones.

Genus Exogone Oersted.

Exogone anomaloch eta $s p$. nov.

(Plate 5, figs. 11-13.)

Several small worms, measuring about $6 \mathrm{~mm}$. in length, with about 36 segments, agree pretty closely with $E$. heterosetosa McIntosh, so that it is unnecessary to give a detailed account of them. Nevertheless, there are two differences from that species which render it necessary to establish a new one.

The tentacles spring close to the anterior margin of the prostomium, and in this respect differs from the above species. (See Ehlers, 1897, pl. III, fig. 61.) They are unequal in size ; the median is spindle-shaped, shorter than the length of the postomium; the laterals are ovate and shorter than the inedian.

'The peristomium bears a short ovate cirrus, and just above it a nuchal organ, such as Gravier figures for $E$. turqueti (1906, pl. I, fig. 3). The huge palps are longer than the prostomium. The anal cirri are spindle-shaped, and equal in length the anal segment.

* If Faurel is correct in identifying the species with Syllis teeniceformis Haswell, and with T. richardi Gravier, the further localities must be added-Australia, North and South Atlantic, Red Sea, l'ersian Gulf. 
The parapodia spring from near the anterior boundary of the segments, are sliort, and eontain but few chrtx-about 6 in the anterior and 4 in the posterior feet.

There are three kinds of chætæ (fig. 13) - (a) the uppermost simple eapilliform, swollen at the end with a symmetrical but fine point (this is the "aeieulum " of MIcIntosh); (b) the uppermost gomphotrich, whieh differs from that found in $E$. heterosetosa, as will be described below; and (c) some four or five smaller gomphotrichs. These have.ani enlarged end to the shaft and articulated deep down at one side is the short bidentate appendix. They are similar to those in $E$. heterosetosa, but have a more swollen cup. 'The lowest ehætæ have this somewhat less enlarged than the upper ones, but the differenee between them is not very marked.

The uppermost gomphotrieh is not "spathulate" at its extremity. It consists of a slender shaft, whjeh is mueh expanded at its extremity to form a large cup, which when seen from the side is quadrate. Three of its sides or edges are smooth, and in the re-entering angle between two of these the appendix is articulated, the fourth side forming the real free end of the shaft is finely but sharply dentieulate, and its face is striated. The appendix is rather long, curved, and bidentate.

When seen in the other plane-that is, from the front-the swollen end of the shaft is oval, and the free tip of the appendix projeets beyond. It has somewhat the appearance of Ehlers's figure of the chota of $E$. heterosetosa (1897, pl. III, fig. 65), if a line were drawn between the pointed tip and the oval portion; but there are no coneentric lines here in the present species. The previous authors, MeIntosh, Ehlers, Gravier, have stated that this particular chata is "simple" and "spathulate." But in a recent paper Fauvel $(1919$, p. 356) states that it is really a gomphotrich, i.. that it bears a long and delicate appendix ("arête") which, being easily broken off, gives the appearance of being simple. But, even so, the form of the chæta in the worms before me differ so much from the figures that I eannot eorrelate the two, hence the new species.

It differs from $E$. clavator Ehlers, in the absence of the chæta with very long appendices that occur in the upper part of the bundle, as well as in other charaeters; and from E.turqueti Gravier, also in the form of the ehætæ.

The dorsal eirrus is ovate and shorter than the chætigerous lobe ; the ventral cirrus is longer, pointed, and extends beyond the lobe.

The pharynx is lined with a dark-brown cutiele and extends throngh the peristomium and three following segments to enter the barrel-sliaped proventriculus, which oceupies $2 \frac{1}{2}$ segments. This leads into a snb-globular region oeeupying the rest of the 7 th segment, and then follows the intestine.

\section{Locality.-}

Commonwealth Bay and Maequarie Island.

Amongst some material sorted out by Professor Haswell he noted some individnals bearing young ones, which he kindly forwarded to me. 'The young ones are earried on each side of the ventral surface just below the ventral eirri. They form a double serjes of 8 or 9 on each side of the segments 12-20.

*\$3892-D 
Each young one consists of head and 4 chætigerous segments, followed by one segment with a parapod, but without chætæ, and the anal segment carries a pair of long cirri.

Owing to the position of the mother, I am unable to see the characteristic gomphotrich, but as the specimens come from the same locality I have little doubt that it is this species.

\section{Genus Sphжrosylis Malmgren.}

Spharosyldis MCINTOSHI Ehters.

Salvatoria kerguelensis McIntosh (1885), p. 188, pl. XXX, fig. 4 ; pl. XXXIII, fig. 1 ; pl. XV A, figs. 11, 12.

Spharosyllis mcintoshi Ehlers (1897), p. 46.

Sphcerosyllis mointoshi Ehlers (1913), p. 481.

(Plate 1, figs. 4-6.)

Ehlers has laready shown that Salvatoria of McIntosh is in reality a Syllid belonging to Malmgren's genus. McIntosh, although he placed the worm amongst the Hesionidæ, recognised in the course of his account that in several features it approached the Syllidx.

In the present collection I find specimens of this small worm amongst those taken in Boat Harbour during the month of June, 1912, in 3-4 fathoms of water.

They are only $3-4 \mathrm{~mm}$. in length with $28-33$ segments. The tentacles and the dorsal cirri have swollen bases and narrowed tips, but are not so short and stumpy as in the typical Spharosyllis. The rounded prostomium (figs. 4, 5) carries three tentacles, two pairs of eyes, and a pair of palps ; the last are fused and project beyond the prostomium. Ventrally this region is deeply furrowed in the median line indicating the double nature of this organ. McIntosh, it will be remembered, denied the existence of the palps; but his specimens were soft and ill-preserved.

He was, I think, in error too in stating that the filamentous tapering extremity of tentacle and cirrus is "distinctly segmented," for in my specimens, which are well preserved, there is no indication of this, though there are a few quite irregularly disposed constrictions along this region, when the animal is mounted in glycerine.

I have thought it well to give a careful drawing of the head (fig. 4) as McIntosh's figure, the only one as far as I know that has been published, is misleading.

The peristomial cirri are short. The following segments carry long parapods, each with a single bundle of chætæ, a dorsal cirrus, and a short cylindrical ventral cirrus which extends beyond the chrtigerous lobe.

The chætigerous lobe is supported by two acicula, each of which is swollen just below the point (fig. 6). Below these are 8-10 chætæ, the uppermost of which is capilliform, as McIntosh has noted, while the rest are gomphotriclis of the form shown in his figure. 
The anal segment carries a pair of cirri similar to the dorsal cirri.

The extent of the pharynx and the proventriculus (or stomach) agrees with that shown in his figure.

I received some specimens from Dr. Haswell in which eggs were attached to the parapods.

Ehlers has described the epitokous phase.

\section{Locality.-}

Boat Harbour, Commonwealth Bay, 3-4 fathoms.

Distribution.-Kerguelen (MeIntosh), South Georgia, Kaiser Wilhelm II Land (Ehlers).

\section{Sub-family AUTOLYTE⿺. \\ Genus Autolytus Grube. \\ Autolytus chaRcoti Gravier.}

Gravier (1906), p. 7, pl. I, figs. 1, 2.

(Plate 5, figs. 7-10.)

Of this species, both the atokous and the epitokous phases of both sex are represented ; the latter have not hitherto been described.

\section{Atokous phase.}

Of the seven specimens of the atokous phase in the collection, some were still within thin transparent membranous tubes ; of which one measures $30 \mathrm{~mm}$. in length and $4 \mathrm{~mm}$. in diameter. The tubes were attached to one another, side by side, forming a small mass; and to one was attached a portion of a colony of a Hydrozoon.

The contained animal is complete and measures $26 \mathrm{~mm}$. in length, with a breadth of $3 \mathrm{~mm}$. at about $\frac{1}{3} \mathrm{rd}$ of its length, whence it tapers slightly both anteriorly and posteriorly; it contains 70 segments. The body is flattened dorso-ventrally and has height of $2 \mathrm{~mm}$. (fig. 7). Another individual, from Boat Harbour, was free from its tube ; is $18 \mathrm{~mm}$. in length and $1.5 \mathrm{~mm}$. across the body, which is built up of 68 segments or more, the last few being very small. Smaller worms were also present, one of which with a length of $6 \mathrm{~mm}$. was stained and mounted entire. It is still within its thin tube and came from the same station in Commonwealth Bay as that first mentioned.

Gravier had only two specimens, one of which was entire, and is smaller than some of those before me.

The worms are pale-brown in colour with a transverse bar of somewhat darker tint across each segment, the width of the bars being rather greater than the pale space separating them. As Gravier has noted, this banding is more marked towards the middle of the body length.

The first mentioned worm is full of eggs, though the body is not yet differentiated into regions ; there are none of the characteristic long slender bristles that indicate the epitokous phase. 
Passing backwards from the prostomiun are two eonspicuous white broad ridges, the "epaulettes" or " ailerons," whieh eross over the peristomium and two following segments just"above the bases of the dorsal eirri and end at the hinder margin of the third segment. Each of these structures is grooved along its upper surface, and its imner margin is thickened, rounded, and opaque white; they show well against the pigmented surfaee of the dorsal surface. Though so eonspicuous in the worm viewed by reflected light, they are scarcely visible in a stained speeimen mounted in Canada balsam.

The peristomial dorsal cirri are about as long as the prostomial tentacles. The ventral cirri of this segment are short. On the next two segments the dorsal eirri are longer still, though their exaet length is difficult to estimate as they are coiled.

The dorsal cirri are eylindrical, smooth, and though presenting irregular constrietions here and there, are not truly moniliform; eaeh is marked by a streak of brown pigment along its external and internal faees.

On the ventral surfaee there is, on each side, a series of segmentally arranged great oval glandular pads sueh as MeIntosh deseribes for his Autolytus maclearanus. I suggest that these glands are responsible for the membranous tube in which the worm lives.

The anterior dorsal cirri are as long as the width of the body, but deereases in length posteriorly, so that in the mid-body, their length is about half this width, and they become still shorter further back.

The form of the parapod (fig. 7), and the arrangement of the chætæ are as Gravier has described, though the ventral glandular pad is more definitely eonstrieted off from the body on the ventral surface than his figure indicates. The parapod is supported by a.couple of acicula lying elose together side by side ; and carries, besides the bundle of compound ehætæ, one or two capilliforms ; it is, however, only exceptionally that one can deteet them owing to their fragility.

The eup of the "gomphotrich" or compound chæta (fig. 8), is eharaeteristically striated on one side, the appendix is, as usual, short with two unequal teeth, of which the distal is slenderer than the other; the latter presents slight differences according to its position in the bundle ; in the lower chætæ it is sharply pointed as is the distal tooth; whereas in the upper ones it is usually bluntly rounded as if subject to wear. The form of the appendix does not quite agree with the figure given by Gravier (p. 8, fig. 1), as I find that there are no serrations below the teeth. It seems also to be somewhat broader in proportion to the length than is shown by that figure.

The pharynx, which Gravier was unable to study, extends back to the end of the 7th segment, where it bends forwards on itself, then turns baek to enter the "stomach" (or proventriculus), which oeeupies apparently segments 10-14 as seen in a specimen that I disseeted; but in a mounted specimen of smaller size, this stomaeh oecupies segments $7-10$. Whether this differenee is due to age or to a disarrangement during dissection I eannot say. 
Remarks.-From these southern seas, four species of Autolytus have been reeorded- . A. maclearanus MeIntosh, A. gibber Ehlers, $A$. simplex Ehlers; in aldition to Gravier's species. But the last is the only one in which the "ailerons" are developed, as Ehlers has pointed out (1913).

\section{Epitokous phases.}

A considerable number, some 3-4 dozen, of male and female epitokous stages were collected on the surface at Boat Harbour. They are deseribed by Dr. McLean as being "reddish in colour." In the preserved state some are deep brown, others pale brown, and others again almost white ; they all agree in their strueture though it may be that the darker ones are older than the rest*.

The brown ones are of deeper tint on the ventral than on the dorsal surface, whieh suggests that the worms swim on their backs at this time. Naturally they vary in length, the majority being from 12-18 $\mathrm{mm}$. In eaeh case I have chosen for deseription one of the largest speeimens.

\section{Sacconereis.}

The majority of the females have lost the ventral egg-sac, though this is still present in one that was mounted, where it lies behind the 15th chætigerous segment.

A complete large individual, measuring $38 \mathrm{~mm}$. in lengtl with a breadth of $5 \mathrm{~mm}$., consists of a "head" with 14 unmodified segments, plus 40 segments with longer parapods, each carrying a bundle of long capilliform notopodial bristles ; this region is followed by 30 unmodified posterior segments.

The head in this phase undergoes little modification; there are no additional prostomial appendages; but the eyes are enlarged, specially those of the anterior pair which have become thrust down to the under surface.

The ailerons are distinet.

The dorsal surface of the body is marked by intersegmental bands of yellowish brown pigment which encroach more or less on to the surface of the segments. The dorsal cirri retain the colouration of the atokous phase, brown with a white line along each face.

\section{Polybostrichus.}

In the male, the prostomium is white, but the appendages are more or less deeply tinted. The tentacles are brown on the anterior or ventral faces, and white dorsally ; the frontal tentacles, like the "bifureated appendages," are deep brown ; the dorsal cirri are paler dorsally than ventrally.

A complete individual, measuring $32 \mathrm{~mm}$. in length, consists of a "head" with 14 unmodified chætigerous segments, followed by 45 segments with long capilliform bristles, behind which are again some 20 unmodified segments.

* When placed in water previous to being stained in alum-carmine the pignient is dissolved, and the water becomes coloured an orange-brown, 
The transversely extcnded prostomium (figs. 9-10) bears the usual large eyes, arranged as in the Sacconereis. Springing from the upper surface near the hinder border is the long median tentacle, which is about $5 \mathrm{~mm}$. in length. The lateral tentacles are noticeably larger, being about twice the thickness of the median and of grcater length. That region of the prostomium from which they arise has apparcntly been pressed backwards and downwards, so that the pcristomial cirri appear, in dorsal view, to be in front of them. Below the base of thesc long latcral tentacles is a large swollen subspherical mass overhanging the clixtigerous lobe of the second segment. It is upon this mass that the lateral tentacles stand.

From the anterior margin, between the cyes, the club-shaped "frontal tentacles" arise, and below them the "bifurcated appendages" (which according to Malaquin represent the united palps and lateral-anterior tentacles, a view that Ehlers does not accept). I prefer to use the above term so as to avoid any morphological controversy. These " bifurcated appendages" consist of a thick basal region which divides into two branches, one shorter and thicker and fleshy; the other longer and slenderer. The former appears to be a continuation of the basal region (than which it is rather longcr), and so to constitute the main axis ; the latter branch is borne on the under and outer face of the fleshy portion; it is about $\frac{1}{3}$ rd the length of the median tentacles, but as both are coiled, it is difficult to give rrecise measurements.

These organs spring from the prostomium below the frontal tentacles at a level of a line drawn across between the dorsal and ventral pairs of eyes: their bases touch ventrally. Their position on what appears to be the morphological dorsal surface of the prostomium seems to negative the view that they are palps unless their origin has shifted upwards, as that of the lateral tentacles lias shifted downwards.

Both the basal region of the appendage and the thicker branch are ur arked by a series of granular rings from which spring hairs, some of which in a mounted specimen are curved. Presumably they are sensory hairs. Unfortunately they are invisible in Canada balsam mounts, though clearly seen in glycerinc preparations.

The ailerons or epaulettcs are present, extending across the bases of the large tentacles and, as in the atokous phase, reach to the hinder end of the third segment.

In some specimens, but not in all, there is a linear white ridge passing backwards from the prostomium in the middle line over the first six or seven segments. I noticed it both in large and small individuals, in dark and in pale ones, while in others it is not present. I failed to detect it in the Sacconcreis. Although visible in reflected light it is not to be seen in any of the mounted specimens. Has this low linear ridge anything to do with the "birnförmig Höcker," which Ehlers describes and figures for this Pterautolytus (1907, p. 8). This is a small pear-shaped upstanding structure on the mid-dorsal line of the 2 nd segment. On p. 10, he compares it with certain " occipital Höcker" which occur in some other syllids, suclı as Syllis notocera Ehlers and Autolytus gibber Ehlers; in the latter, however, it is merely a broad round-cdged lobe overhanging 
the back of the prostomium. .. I have failed to find anything like this linear longitudinal ridge in any Syllids figured by Ellers, Gravier, or other authors.

On the ventral surface, the prostomium is notched on its hinder margin and the borders are deeply pigmented. The anterior segments of the body are provided witlr large ventral glandular pads as in the atokous plase; and in the pale-coloured reddislr individuals, these are very conspicuous owing to their opaque whiteness.

Locality of Atokous forms.-

Boat Harbour, surface $3 \frac{1}{2}$ fathoms (three specimens); and Commonwealtli Bay, 25 fathoms (four).

Locality of Epitokous phases.-

Boat Harbour "taken in hand-net at the surface," on 8 , VII, 12; 7, IX: 12 and $14, \mathrm{IX}, 12$.

Distribution.-Port Charcot (Gravier).

\section{Family APHRODI'TIDA.}

Sub-family Aphroditinks.

Genus Latmonice Kinberg.

Latmonice producta Grube.

Grube (1877), p. 512 .

McIntosh (1885), p. 39, pl. VI, figs. 1, 2 ; pl. IV A, figs. 1-8.

Ehlers (1908), p. 40.

Ehlers (1913), p. 438.

Gravier (1911), p. 80.

Moore (1903), p. 420; and various other authors.

Seventeen individuals of this handsome annelid were obtained. It has been so fully described by McIntosh that nothing more need be said of it here.

Localities.-

Station 3, 157 fathoms (one).

Station 11, 358 fatloms (one).

And fifteen specimens without any data.

Distribution.-Kerguelen (Grube, McIntosh), Heard Island (McIntosh), Kaiser Wilhelm II Land (Ehlers), Graham's Land (Gravier), Japan (Moore).

L. PRoducta var. Benthaliana McIntosh.

McIntosh (1885), p. 45, pl. V III, figs. 4, 5 ; pl. IV A, fig. 12 ; pl. V A, figs. 1, 22. Moore (1903): p. 420.

A single indjvidual was obtained by Professor Flynn off Maria Island at a depth of 1,300 fatlioms. 
This is an instance of the wide distribution of animals living at great depths for it has been recorded from the Antarctic to the coast of Japan.

It has been met with by the "Challenger" at the following places:-Between Trince Edward Isl. nd and Kerguelen, at a depth of 1,600 fathoms. Midway between A ustralia and the Antarctic, at 1,950 fathoms. Also in the North Pacific (lat. $35^{\circ} 41^{\prime}$ N., long. $157^{\circ} 42^{\prime}$ E.) at 2,300 fathors, and (lat. $35^{\circ} 22^{\prime}$ N., long. $169^{\circ} 63^{\prime}$ E.) at a deptli of 2,900 fathoms. While Moore records the variety from the coast of Japan at 3,774 fathoms.

Sub-family Polynoina.

Genus ENIPo Malmgren.

ENIPO RHOMBIGERA Ehlers.

Ehlers (1908), p. 47, pl. IV, figs. 1-12.

Ehlers (1912), p. 13.

Ehlers (1913), p. 449.

Gravier (1911), p. 81.

Of this very distinctly "patterned species, which is confined to the Antarctic region, as many as forty-two specineus were gathered by the "Aurora" from eight stations and from one unnamed locality.

The plan of colouration is sufficiently described and illustrated by coloured figures by Ehlers, and some other variations of pattern. are mentioned by Gravie.: I have only to add that in one specimen, which measured $100 \mathrm{~mm}$., the dorsum is very darkly coloured. The violet median band, with its rhomboidal ontgrowths, is nearly continuons on the elytriferous segments; with a streak of dark brown along the hinder half of the segment; while in the cirriferous segments, where the median band is not produced outwards, there are two parallel cross-bars of brown, extending inwards from the cirrophore, one in front, the other belind it, nearly meeting the median pigmented band.

The greatest length of any of my specinnens is $100 \mathrm{~mm}$., though others have been previously described that exceed this.

The figure of the head given by Ehlers is not quite satisfactory, since the median tentaculophore is so drawn as to suggest that it bore the tentacle (which is missing, as it usually is) on its upper surface, which would be a very unnswal position in the family. As a matter of fact, however, it is the fault of the artist, for I find that the tentacle is inserted at the anterior extremity of the tentaculophore as usual.

\section{Localities.-}

Commonwealth Bay, Station D, 45-50 fathoms (two).

Station E, 55-60 fathoms (four).

Station 1, 350-400 fathoms (nine). 
Station 2, 318 fathoms (five).

Station 3, 157 fathoms (threc).

Station 8, 120 fathoms (ten).

Station 10, 325 fathoms (two).

Station 12, 110 fathoms (four).

Distribution.-South Victoria Land, Bouvet Island, Kajser Wilhelm II Land, (Ehlers), Graham's Land, Alcxander Land (Gravier).

Genus Hololepidella Willey.

Hololepidella flyni $s p$. nov.

(Plate 5, figs. 14-20).

The species is founded on four slender worms eollccted off Maria Island, '1 asmania, by Professor 'T. T. Flynn. The pale grey dorsum is covered by white and nearly opaque elytra, which occur almost over the entire length of the body.

The largest individuat is about $40 . \mathrm{mm}$. in length and contains 63 segments. Its greatest breadth is in the region of segments 5-13, where it measures $4 \mathrm{~mm}$. over the body; $5.5 \mathrm{~mm}$. across the parapods; and $7.5 \mathrm{~mm}$. including the eliætæ. From this point the body begins to taper so that at the 26 th segment the breadth is only $2.5 \mathrm{~mm}$., while at the 40 th it is but $2 \mathrm{~mm}$. The lcngth of the parapods does not sensibly decrease till quite elose to the hinder end.

The total number of elytra is rather difficult to decide, as the majority have fallen away; but by counting the elytrophores I find that there are at least 26 pairs. In a small individual; which measures $27 \mathrm{~mm} . ;$ with 61 segments, 18 pairs of elytra are in position, the last being on scgment 41, but there are elytrophores posterior to this.

I find, as did Willey, that it is by no means easy to distinguish elytrophores from cirrophores, from whieh the eirri have fallen away, both arc nearly in the same line, close to the margin of the body; but by comparing the four spceimens and espeeially after the examination of one that was stained and mounted, which lacks, however, the last 2-3 segments, one can fairly readily distinguish the two, structures.

In this species the elytra are arranged as follows :-The first 12 are on the usual segments, that is (eounting the peristomium as 1 st) on the segments $2,4,5,7-21,23$; the next six elytra appear to be regularly on every third segment $-26,29,32,35,38,41$. It is hereafter that irregularity creeps in, but in all the four individuals I find elytra or elytrophores on the next segment, 42nd; in two instanees they oceur on the next two scgments, that is, on three consecutive segments. Further back they are either on alternate segments or with gaps. of two or three segments at intervals; or on consecutive segments. The arrangement is not symmetrical, so that no general statement eovers their position; no formula ean be given for these posterior elytra.

-83892- E 
Willey (1905, p. 251) found a similar irregularity in $H$. commensalis. I place the facts in tabular form for reference:-

\begin{tabular}{|c|c|c|c|c|}
\hline \multirow{2}{*}{$\begin{array}{l}\text { Number of } \\
\text { Elytron } \\
\text { in the series. }\end{array}$} & \multicolumn{4}{|c|}{$\begin{array}{l}\text { Posterior elytra of right side carried by } \\
\text { the seginents in each of the four } \\
\text { specimens. }\end{array}$} \\
\hline & A. & B. & C. & D. \\
\hline 19 & 42 & 42 & 42 & 42 \\
\hline 20 & 45 & 46 & 43 & 43 \\
\hline 21 & 46 & 48 & 44 & 44 \\
\hline 22 & 47 & 51 & $\ldots$ & 46 \\
\hline 23 & 49 & $\ldots$ & $\ldots$ & 48 \\
\hline 24 & 50 & $\ldots$ & $\ldots$ & 50 \\
\hline 25 & 55 & $\ldots$ & $\ldots$ & 54 \\
\hline 26 & 56 & $\ldots$ & $\ldots$ & 58 \\
\hline 27 & 57 & $\ldots$ & $\ldots$ & $\ldots$ \\
\hline
\end{tabular}

\footnotetext{
$A$ is the stained and mounted specimen.

In $\mathrm{B}$, only 22 pairs of elytra werc present, the remainder of the 58 segments being cirriferous.

$\mathrm{C}$ is soft, and it is impossible to distinguish the elytrophores from the cirrophores.
}

The elytra, except the first which is circular, are oval with the longer axis oblique to that of the body; and in the better preserved specimens they overlap from side to side. The "areola" is near the external margin, the surface is smooth, and there is no marginal fringe.

The prostomium (fig. 14) is colourless, broader than long; the eyes are large, the posterior pair far back, latero-dorsal in position, with a large lens; the anterior pair are lateral, with the lens directed forwards ; these are situated at the broadest part of the prostomium, which is rather in front of the the middle of its length. The prostomium is produced into distinct "peaks," immediately above the base of the lateral tentacles. The tentacles are smooth, tapering to a point; the median is about twice the length of the laterals and longer than the palp. The laterals are about $\frac{2}{3}$ rds the length of the palp.

The parapods (fig. 15, 16) are short, and distinctly divided into two nearly equal lobes. The notopod, of less height than the neuropod, is like it produced into a long and slender aciculum-containing process. The dorsal cirrophore overhangs the chætigerous lobe ; the cirrus is smooth, tapering, very long and easily broken off.

The notopod contains only about 8-10 short yellow straight and stout chætæ with extremely fine transverse lines which appear to represent the "pectinated" frills of other genera, and these lines in older bristles are often worn away (fig. 20). 
The ventral chrotre (fig. 17-19) are about twenty-four in number; each is, shaped like a spear head, the frilled region is short and marked by many very fine closely-set pectinated frills which take an undulating course across the bristle, and are visible along both edges. The chxtx are not all alike, some being more slender and having a longer frilled region than others. The frills commence at some distance from the tip, which is curved and carries a short sub-apical tooth.

I have placed this species in Willey's genus, which is defined as follows:"A polynoid; antennx arising at a lower level than the tentaculum impar, segments and elytra numerous." It does not fit into any other genus, though it is remarkable that the two species should occur in such widely separated localities, the type spccies living on the shores of Ceylon.

Locality.-

Off Maria Island, Tasmania, 1,300 fathoms.

\section{Genus Physalidonotus Ehlers.}

\section{Physalidonotus Rugosus Benham.}

Benham (1915), p. 182, pl. XXXVIII, figs. 16-22; pl. XXXIX, figs. 23-25.

Two individuals were obtained in the neighbourhood of the spot at which the type was taken.

Locality.-Off Maria Island, Tasmania, 65 fathoms.

Distribution.-Bass Strait, coast of Victoria.

\section{Genus HaRмотное Kinberg sensu-lato.}

Harmothoe spinosa Kinberg.

H. spinosa Kinberg (1855), p. 386 .

H. spinosa Kinberg (1857), p. 21, pl. VI, fig. 31 .

Polynoe fullo Grube (1877), p. 515.

$P$. vesiculosa Grube (1877), p. 514.

Lagisca antarctica McIntosh (1885), p. 80, pl. XIII, fig. 1; pl. XVI, fig. 3 ; pl. XVIII, fig. 1 ; pl. VIA, figs. 10-11.

L. magellanica McIntosh (1885), p. 82, and the varicties of this spccies.

H. spinosa Ehlers (1897), p. 12.

H. spinosa Willey (1902), p. 264, pl. XLI, figs. 1-4; pl. Xl_l Il, figs. 1, 2, 4-8.

H. spinosa Ehlers (1908), p. 43.

H. spinosa Ehlers (1912), p. 10, pl. I, fig. 8.

H. spinosa Ehlers (1913), p. 438, pl. XXVI, figs. 1-12.

H. spinosa Gravier (1906), p. 33.

H. spinosa Gravier (1911), p. 88, pl. V, figs. 54-59 ; pl. VI, figs. 64-69.

H. spinosa Fauvel (1916), p. 421, pl. VIII, figs. 8-9 (chrtxe).

H. spinosa Fauvel (1917), p. 179, pl. VI, figs. 47-48 (head).

(Plate fig. 21.) 
Ehlers gives some coloured pictures of this common Antarctic Polynoid, in his account of the National Antarctic Expedition, and of its varieties, in the report of the German South Polar Expedition, above referred to.

In the "Challenger", report, McIntosh figures the head and the chrotre of the species and varieties as distinguished by him; and Willey represents the general appearance of the animal and the characteristic tubercles on the elytra.

For a full list of the synommy and literature consult Ehlers (1913).

The species is evidently extremely abundant in Commonwealth Bay, as 169 individuals are included in the collection, obtained from depths varying from 2 to 400 fathoms, and it probably lives along the shore also, as Ehlers has noted its abundance along shore at all seasons of the year at Kaiser Wilhelm II. Land.

It is, as is well known, extraordinarily variable in colouration, and Ehlers has figured several of the more usual types.

I find large as well as small individuals in which the elytra are colourless, so that the worm has a greyish appearance, though the more typical colonr is some tone of brown, usually a chestnut, with or without a purplish tinge.

In some the elytra are uniformly tinted; in others the pigment is in definite patches, which are either small and scattered irregularly over the surface, or arranged in definite lines parallel to the long axis of the worm; in still others the patches are so closcly crowded together that they produce a nearly uniform darker tone.

In most cases the "areola," that is the area above the attachment of the elytron to its elytropore, is without pigment. In some individuals a reddish-purple spot or even a violct spot lies behind this areola; or, again, this is reinforced by an additional purple splash near the postcrior extcrnal border ; this spot may occur both in pale and in darkly pigmented elytira.

The upper surface of the elytra is often iridescent, and so adds to the beauty of the worm, giving as it does a bluish tinge to the brown in certain parts of the elytron, according to the angle at wlich light is reflected from it.

Further, the body wall is pigmented in various ways, and in various tints independently of the colonr of the elytra. In some specimens the dorsum is almost without pigment, but it is usually crossed by narrow bars of brown or olive, which are confined to the median region of the back. Very frequently there is a tesselated, or chess-board pattern of brown or of olive-green, or of both colours combined, giving a beantiful effect (fig. 21). In such cases the pigment is in the form of quadrate patches on each side of the middle line on alternate segments, the median line being white; and in the intervening segments, the sides are pale and transverse bars of pigment cross the middle line.

But the most remarkable variant is found in the largest individuals, where the entire dorsum is a uniform steel-blue or indigo-blue, or purple (as in Ehlers's fig. 1, 1913), with the bases of the parapods white or pale pink, or of a rather deeper lilac colour. 
In one case the belly is nearly as deeply pigmented blue as the dorsum; but this is very exeeptional, as the ventral surface is generally without pigment.

'There seems to be no very definite eorrelation between the eolouration and the depth at which the worms were found, for in sorting out the specimens. from the jars in which they reached me, I rather naturally separated out those in which the colours were strikingly different, under the impression that I had to deal with distinct species. 'Thus, in one lot from 25 fathoms, I find four different plans of eolonration or, as I supposed, four different species.

Nevertheless, after tabulating the worms under their colours and their depths, it seems that there is a rongh correlation between them. Thus, in shallow water, from the shore line down to 60 fathoins, the general tone of colour of the elytra is darker and variegated in brown, while the dorsum is without pigment, or has pale transverse lines of brown. The elytra, too, are more firmly attached to the elytrophores than in other eases.

But in those worms that come from greater depths, say, 110-400 fathoins, the elytra are paler and more uniformly coloured, and may even be colourless and transhicent; and they are readily decidnous. On the other hand, the dorsim is now pigmented more deeply or more extensively, and it is from these depths that the handsome dark blue and violet worms were obtained. But this applies only to the larger specimens.

The smaller 'worms are apparently less affected by depth; or it may be that the change in the amount of pigment is a measure of age, for in a general way the smaller individuals are deeply coloured, while the larger ones, above $60 \mathrm{~mm}$. in length, have pale or colourless elytra, with a more deeply pigmented dorsum. The smaller worms, from 10-30 mm. are generally found in less deep water than those from 40-90 mm.

The texture and ornamentation also of the elytra present considerable range of variation, for in some the surface appears under a lens to be smooth, whereas in the more typical forms there is a row of pale conical tubercles along the posterior border, as shown in Willey's figure 2, pl. XII. These are usually better developed on the elytra from the hinder region of the body, while the more anterior ones may be without them. Again the entire surface may be covered with small cones, visible under a lens, and giving them a rough appearance to the naked eye. The marginal fringe may be present or absent.

The prostomium is usually white, whether the dorsum of the body is pigmented or not, but in one case at least, it is marked transversely by a narrow band of brownish pigment (as in var. lagiscoides, as fignred by Gravier (1911), pl. VI, fig. 64). The peristomial cirri, anal eirri, and dorsal eirri are brownish.

In spite of these variations in colour there are two features in the distribution of pigment that appear to be constant, namely:-(1) the dark greyish-blue tint on the 
upper lip of the mouth, and especially along its median line, on the ridge which extends upwards to the anterior margin of the prostomium; and (2) the elongated lips of th? notopodial and neuropodial lobes are coloured dark brown or purplish brown.

These two features I found very useful in distinguishing readily the spccies from H. tuberosa.

As to the chætæ. The latest drawings are those of Fauvel (1916, pl. VIII, figs. $8,9)$. He shows the dorsal chæta as having a row of stout spines along one cdge, each spine being apparently the enlarged marginal tooth of one of the pectinated frills. My own observations do not bear out this interpretation; the frills certainly project a good deal beyond the edge, and the appearance produced is of rather stout spines, but I interpret this as being due merely to the fact that two or more of the pectinations are here secn one over the other, producing indistinct thickening of the frill. I do not find definite spines here, nor do other authors.

In the ventral chætæ, however, there are in the distal frills definite spines which are shown by Willey (pl. XLIII, fig. 2).

In this paper (1902) Willey distinguishes "three principal allotypic modifications" of the species, one of which he retains as a distinct species, and refers it to McIntosh's Lagisca crossetensis. The other two are described as varieties of $H$. spinosa, namely, "var. typica" and "var. fullo," with a sub-variety "lagiscoidev." The two latter varieties are characterised by, among other things, the presence of long conical tubercles or spines on the elytra; the last variety by the fact that the lindmost segments are not cervered by the elytra.

Gravier (1911) describes in detail examples of the two varieties, "typica" and "lagiscoides," and mentions that the latter has the elytra more deeply pigmented than the former.

I have, as already noted, a very large series of the species-but I have failed to find any in which the hinder segments are thus exposed. It is true that I have not been able to give the time to sorting out of this series into groups or varieties, and the range of variation in several characters is very considerable, as Ehlers lias shown, yet both in large and small specimens, in those with dull and in those with bright colouration the elytra cover the whole body. It must, however, be noted that in many cases the elytra had fallen away ; but I find, as Gravier did, that none of those examined with this purpose possess as many as forty scgments, the number given by Willey for this particular individual. Is it possible that he had under obscrvation some other species?

\section{Localities.-}

Boat Harbour-

2-4 fathoms, coll. by Dr. A. I. McLean (fourtecn).

$3 \frac{1}{2}$ fathoms, coll. by Dr. A. L. McLean (twenty-one).

$4 \frac{1}{2}$ fathoms, coll. by Dr. A. L. McLean (three). 
Commonwealth Bay--

Station B, 25 fathoms (sixty-five).

Station C, 15-20 fathoms (fourteen).

Station D, 45-50 fathoms (twelve).

Station E, 55-60 fathoms (eleven).

Station 1, 340-400 fathoms (nine).

Station 3, 157 fathoms (one).

Station 8, 120 fathoms (five).

Station 10, 325 fathoms (two).

Station 12, 110 fathoms (twelve).

Distribution.-Magellan Strait (Kinberg, Grube, McIntosh), Marion Island, Prince Edward Island (McIntosh), Cape Adare (Willey), Coulman Island, Kaiser Wilhelm II Land (Ehlers), Graham's Land (Gravier), Falkland Islands, St. Vincent Gulf and Spencer Gulf, South Australia (Fauvel).*

One of the specimens from Station $C$ has a parasitic Copepod attached between two of the parpaodia, as figured by Willey (pl. XLI, fig. 4).

\section{Harmothoe tuberosa Ehlers.}

Harm othoe spinosa, variety Ehlers (1908), p. 43.

Harm othoe tuberosa Ehlers (1912), p. 11, pl. I, figs. 1-7.

(Plate 6, figs. 22-29.)

The account given by Ehlers, apart from one or two details, is adequate. The coloured figure represents a much redder tint than is exhibited by any in the present collection, where the worms are grayer, sometimes paler, sometimes darker, sometimes with a purplish tone, sometimes bluish, and usually with a metallic lustre.

It does not appear to attain the dimensions of $H$. spinosa, for the largest individual measures only $50 \mathrm{~mm}$., with a diameter over the elytra of $15 \mathrm{~mm}$. The body itself, measured on the ventral surface at segments $7-18$, is $7 \mathrm{~mm}$. across: thence it tapers gradually, so that at the 26 th segment its breadth is $5 \mathrm{~mm}$.

The species is apparently much rarer than H. spinosa, for though it occurred in eight hauls, which yielded twenty-six individuals, and except at a depth of $2 \tilde{5}$ fathoms (Station B), only one or two were obtained in a haul. It is apparently commoner at the less depths, for at this Station B as many as fifteen specimens were brought up by the dredge.

* Fauvel mentions a specimen as occurring as a commensal in a tube of Thelepus ap. 
It occurs in each case in company with $H$. spinosa, but in much less numbers. For example, whereas at 15-20 fathoms fourtecn specimens of $H$. spinosa were obtained, there was only one of $H$.tuberosa; at 25 fathoms, in contrast with sixty-five specimens of the former, there were only fifteen' of the latter. Although Ehlers originally regarded it as a variety of $H$. spinosa, since it seems nearly always to occur in association with it, yet in his later work he pointed out that it is a very distinct specics.

There are one or two features which readily serve to distinguish it at sight from H. spinosa: (1) The dorsal chætæ, instead of projecting outwards, have a radiating arrangcment, as is shown by Ehlers's figure ; (2) The absence of pigmentation of the upper lip and of the ends of the parapodial lobes (" acicular processes ") which is practically universal in $H$. spinosa.

The dorsal surface of the body is free from pigment, so far as my observations go, but the lateral longitudinal ridges along the ventral surface are crossed by bars of brown, and the posterior feet may be pigmented on their lower faces. The ventral surface thus appears dark.

Ehlers has directed attention to the peculiar transverse "pads" which occupy the median line of the dorsal surface in cach segment, and the "cushions" on the cirriferous segments in line with the elytrophores, the cirrophores being situated far out on the bases of the parapodia. Both these structures occur also in the genus Physalidonotus, which Ehlers founded for a Branchiate Polynoid from New Zealand, in which the head, however, is "lepidonotan." Having had several species of this genus under examination recertly, it occurred to me that possibly there might be gills here also, but on investigation I find that they arc absent.

The dorsal chætre are "bearded" in the same sort of way as are those of Physalidonotus. It is evident that Ehlers had before him and has figured a much-worn chæta, and that he failed to recognise the true nature of this "bearding," for he writes, "ich mag nicht entscheiden, ob diese Faden durch Aufsplitterung des Borstenendes cntstanden oder epiphytische Bildungen sind."

To me neither of these cxplanations of the appearance presented by the chrtæ is the correct one. These long "Faden" are similar to those originally figured by Moore (1903) for certain species, which he named Lepidonotus branchiferus and L.chitoniformis (pp. 405, 409, pl. XXIII, figs. 7 and 10), which really belong to the genus Physalidonotus. More recently I have figured the chætæ for $P$. rugosus and $P$. paucibranchiatus (Benham 1915, pl. XXIX).

A morc detailed account of the dorsal chætæ of $H$.tuberosa is, therefore, desirable. In a perfect unworn chæt $x$ the tip is smooth and rather bluntly pointed. Below this smooth region there come three or four pectinated frills* which arc produced into long 1883.)

* This term was used by A. G. Bourne in his account of the chæta of Lep. clava. (Trans. Linn. Soc. London., vol. ii, 
delicate hairs, extending beyond the tip, surrounding it and more or less eoneealing it. Similar but less developed frills follow and oceur along the greater part of the chxta (fig. 22).

When studied under a higher power the elixta appears to be triangular or possibly quadrangular in section (figs. 23, 24). Along two edges are ranged two series of spines or teeth, which decrease in size as they are traced downwards proximally. Fach pair of teeth is connected across the "front" of the chxta by a finely-striated inembrane or pectinated frill, the margin of which is comblike, as if it were made up of many very delicate chitinous hairs closely set side by side. In the more distal of these combs the hairs gradually increase in length, and beco ne flexible until the long hairs that form the "beard" are produced. Similar but less developed frills extend outwards beyond the teeth, down the " sides" of the chætæ, but in the proximal portion this lateral frill $i_{s}$ replaced by a series of minute conical teeth (fig. 24). 'T'he spines or teeth are evidently merely specialisations of the comb-teeth.

The shorter upper chætæ of the bundle have simple frills, but as the chætx get longer the four or five of the distal frills become produced into the long hairs. There is quite a gradual transition between the chætæ with simple frills and those with welldeveloped " beards."

These "beards," as Ehlers notes, entangle mud and debris, so that it is not always possible to obtain a good view of the apex and to make out the real strueture, but in some of my mounts, both in Canada balsam and glycerine jeliy, the apices are fortunately free of mud and the structure is quite apparent.

The ventral chrtx, too, are worthy of closer description than Ehlers has given them. They are quite different from those of H. spinosa, as he has shown.

Each presents two parallel series of short stout teeth or spines along the concave edge, four or five in a series in the case of the longer chrtx, but reduced to three in the smaller ones (figs. 25-27). The more distal spines in each series are simple and toothlike, but lower down each is seen to be surrounded at its base by a pectinated frill, or, lower still, to be replaced by a frill whose edge, under a low power, has the appearance of a tooth (fig. 27). These upper frills have quite a limited extent, but below them eome four to six closely-set small frills of very short pectinations which run right across the chrta from side to side.

The elytra on two of the individuals studied present marked variation from the typical structure. In addition to the characteristic sub-marginal papilla, the elytra bear conical and vesicular tubercles of brown colour. On the anterior elytra they are comparatively small, lying on the uncovered posterior region of the scale, but on the more posteriorly situated elytra the tubercles become more conspicuous. They are here larger, though less numerous, till, on the last six or seven, they are truly enormous vesicles (fig. 28). Whereas the tenth elytron carries some half dozen of these vesicles, the fourteenth bears but one (fig. 29). These vesicles appear to be much enlarged and dilated tubereles. derived from the ordinary echinulate tubereles characteristic of the species. 
Just as there is a variety of $H$. spinosa (Lagisca antarctica or $L$. vesiculosa), so here we have a variety of $H$. tuberosa, differentiated by the great size of the tubercles ; but here they are conical, rather than spherical, and recall those figured by Kinberg for $H$. patagonica (1857, pl. V, fig. $22 \mathrm{H}$ ).

\section{Localities.-}

Boat Harbour, winter quarters, Station A, $3 \frac{1}{2}$ fathoms (one individual).

Station B, 25 fathoms (fifteen).

Station C, Commonwealth Bay, 15-20 fathoms (one).

Station D, 45-50 fathoms (one).

Station E, 55-60 fathoms (two).

Station 1, 350-400 fathoms (one).

Station 3, 157 fathoms (one).

Station 8, 120 fathoms (two).

Distribution. - S. Victoria Land; Bouvet Island (Ehlers).

\section{HaRmoth Oe ABYssorum McIntosh.}

Eunoa abyssorum McIntosh (1885), p. 73, pl. XI A, figs. 14-16.

(Plate 6, figs. 30-35.)

Three specimens of this species were obtained, and as the type was dried up, so that McIntosh was unable to say much about its anatomy, an opportunity occurs of adding to that brief account.

The largest of them is $29 \mathrm{~mm}$. long, with 35 segments, but is imperfect. It is broadest at about segments $7-12$, thence tapering. Here it measures $5 \mathrm{~mm}$. across the body, $10 \mathrm{~mm}$. over the parapods, and $12.5 \mathrm{~mm}$., including the chrtx. At segment 20 these numbers are $3 \mathrm{~mm} ., 6 \mathrm{~mm}$., and $9 \mathrm{~mm}$. respectively, so it is clear that only a few segments are missing.

The ventral surface of the body is purplish, darker posteriorly, and the pigment extends on to the feet, where, however, it becomes fainter. The dorsum is devoid of pigment.

There ase fifteen pairs of elytra, which are present on one of the smaller individuals. 1 hey are colourless, translucent, and rather thick, but towards the external marg:n they become slightly yellowish and opaque. They are smooth not only to the naked eye, but even microscopically, except that over the outer area there are numerous minute, rounded refringent tubercles, which seem to be the cause of the yellowness here (fig. 33).

The prostomium (fig. 30) is broad, with well-developed peaks on the outer side of the bases of the lateral tentacles; both pairs of eyes are on the dorsal surface, and lie behind the middle of its length. The two eyes of one side are thus close together, 
bei g EcI alsted ficmi one arother by alout the diameter of an eye. They are large, and herein there seems to be a difference from the type, of which McIntosh says that it " appears devoid of eyes."

The median tentacle is absent from both speeimens. The laterals spring trom below it (fig. 31 ), and are direeted parallel with it, not divergently as in some species. They are tapering without any subterminal swelling; they bear a few microscopie hairs. In length they are short, being not quite twice the length of the prostomium. The palps are long, smooth, and of a greyish-brown colour.

The parapods are bilobed (fig. 32). The notopod lias a long acieular process which is more slender than that of the neuropod. The anterior feet are longer than the posterior. The ehætæ are pale yellow or, as MeIntosh terms them, "straw-coloured." The dorsal ehrtx are more numerous than the ventral, being $15-20$ in number. They form an upwardly direeted tuft of shorter, stout and straight bristles, and a few in the lower part of the bundle are longer and direeted outwards. The peetinated frills (fig. 34) nearly surround the axis. At any rate, they extend aeross it over the greater part of this region; the distal portion of the bristle is smooth and rather sharply pointed.

The ventral ehætee are few in number, from 5-8, usually 6 . They appear to be in a single vertieal series, deereasing in length from above downwards. They are rather stouter than the largest of lower ones in the notopod, but they are a good deal longer.

The frilled regiou (fig. 35) is rather short, and is somewhat enlarged. The frills are few, some 12-14, and delieate; the distal frills are not eontinuous, but eaels is represented by two or three isolated groups of peetinations, and lower down these extend till they meet and form a eontinuous frill of fine short, hair-like processes, whieh takes an irregular course aeross the bristle and reaehes the eonvex border or "baek." The smooth apex is curved, and there is no sign of a sub-apieal tooth.

The form of the ehætre agrees with the figures given by MeIntosh, though I have added some little details.

Localities.-

Station 10, 325 fathoms (two).

Station 11, 358 fathoms (one).

Distribution.-South of Australia, Lat. $42^{\circ} 43^{\prime}$ South, Long. $134^{\circ} 10^{\prime}$ East, 1,600 fathoms.

\section{Genus Eulagisca McIntosh.}

EUlagisca CORRIENTIS MeIntosh.

MeIntosh (1885), p. 91, pl. XIII, fig. 4 ; pl. VII A, figs. 3, 4.

(Plates 6 and 7 , figs. 36-42.)

The larger of the two specimens of this rare worm is $83 \mathrm{~mm}$. in length, with a diameter of $11 \mathrm{~mm}$. over the body, and $23 \mathrm{~mm}$. over the parapods. It eontains 37 segments. The smaller eonsists of 33 segments, is only $20 \mathrm{~mm}$. by $3 \mathrm{~mm}$. over the body. and $8 \mathrm{~mm}$. ineluding the parapods, which are relatively long. 
Judging from McIntosh's remarks, a structure that seems characteristic is a subtentacular frontal cone, which he refers to as a "sub-tentacular cirrus" thongh this term does not seem altogether applicable to such a short conical process. This "frontal cone " is situated between the bases of the palps immediately below the median tentacle (fig. 37). It is quite distinct and separate from the ridge which forms part of the upper lip, and appears to spring from the underside of the prostomium itself. When the median tentacle is absent, as it is in one of the two individuals, this frontal cone is seen projecting beyond the tentaculophore (fig. 36). It is white with a brown base. McIntosh refers to this "remarkable" organ as being "unique" (p. 93), and in this place does not refer to any other species except some of the Acoctinæ as presenting anything like it. Nevertheless on p. 112, in the course of his account of Polynoe platy. cirrus he does mention that a small cylindrical boss occurs in the same position. I have exanined a specimen of this species and can confirm this statement, but it has a spherical shape and is by no means so noticeable as in Eulagisca. The use of the word "unique" scems to suggest that it is one of the generic characters of Eulagisca, especially as he gives no diagnosis of this or any of the new genera and sub-genera he had occasion to establish. I do not recall meeting with any reference to such a structure in more recent works dealing with the Polynoids; yet it is a structure that is so definite that it may have a wider range and be of value in differentiating some of the species of that puzzling gromp.

The ventral surface of the worm is colourless, the chæta are pale brown. The dorsum is marked with very-pale chestnut brown in the median anterior region, and darker on the peristomium. At about ${ }_{3}^{1} \mathrm{rd}$ of the body length, this continuous band of pigment breaks up into a series of irregular patches which get fainter and smaller till about the last quarter, when they die out.

The prostominm is colourless, though in one specimen it has a crescentic mark of dark brown across each half, which is lacking in the other specimen. There is a small patch of dark-brown on the upper surface of each of the cirriferous segments just within the cirrophore, and in the elytriferous segments a corresponding patch. 'The' dorsal cirri have a ring of very pale brown below the subterminal swelling. The anus is surrounded by a dark-brown area.

'The prostomium is broader than long, has no peaks, and the three tentacles arise in one plane; the anterior region of each half is continued into the tentaculophore, though in the smaller individual, which is less well-preserved than the larger, each half of the prostomium appears to be produced into an internally directed peak; but this is due to the oblique line separating it from the lateral tentaculophore.

The eyes are relatively large, and each is provided with a lens; the anterior are situated laterally about half-way along the prostomial lobe at its broadest part ; the posterior eyes are dorsal, about half-way between the anterior eye and the hinder margin, though they appear further back in the less well-preserved individual. The hinder margur of the prostomium is over-hung by a forward continuation of the peristomium. 
In the smaller individual all the prostomial appendages are present, but they are absent in the larger. The median tentacle is about twice the length of the laterals; they are colourless, even translucent, with an opaque white sub-terminal swelling. 'The tentaculophores are dark-brown, as also are the peristomial cirrophores. The palps are very long, twice the length of the median tentacle; while the peristomial cirri are as long as, or even longer than, the median tentacle.

Although these appendages appear smooth to the naked eye, they are in reality ciliate. McIntosh states that the cilia are numerous in his specimens, but I find them comparatively few and far apart.

The parapods (fig. 39) are not very prominent, the notopod smaller than the neuropod, and each has a long narrow acicular process, that of the neuropod reaching further outwards, but actually the two are of equal length.

The aciculum is colourless, very delicate, and produced into a fine point which projects beyond the tip of the process in which it lies. The dorsal chætec (fig. 40) are 8-10 in number, stouter than the ventrals, the upper ones curved, the lower straight. The apex is short and sharply pointed, bcing slightly concave on one side. The whole chæta is crossed by pectinated frills which only extend for about half-way across the axis.

The ventral chætæ (figs. 41-42) are long, very fine, and somewhat flexible; they have a very long frilled region consisting of about 30-40 frills, and a comparatively long delicate and simple apex. The upper ventrals are nearly straight; the apex long and very fine; the rest have a curved apex rather hooked, but there is no sign of a subterminal tooth.

I note an opacity near the apex of the dorsal chrtæ to which McIntosh refers. The ventrals differ from his figure in the much greater length of the point.

The elytra are 15 pairs, though most of them are lacking in the specinens. The two anterior elytra on each side are thin and splashed with dark s:enna brown; the first one is sub-circular, the second oval (fig. 38). This has a nearly ccntral "areola" with a patch of brown pigment on its outer edge; there are three large, broad, roundtipped conical tubercles near the external margin, and springing from the surface of the scalc between them, but nearer to the margin, are a few long, fine, cylindrical hair-like papillæ. The concealed portion of the elytron bears numerous small, rounded, low, and highly refringent tubercles, only visible under a high magnification. There is no fringe.

\section{Locality.-}

Station 8, 120 fathoms (one).

No data (the larger of the two).

Distribution.-Between Kerguelen and Heard Islands; also Buenos Ayres (McIntosh). 
Remarks.-The "Challenger" obtained only two specimens, one comp'ete and one incomplete and it has not been recorded since. The name Eulagisca seems to me to be unfortunate, as the head is so entirely different from that characteristic for the genus Lagisca. McIntosl w writes: "The bristles are allied to those of Lagisca, while the eyes, scales, ventral papillæ diverge. The subtentacular cirrus is unique and is akin to the proboscidian process of Acoetidæ."

\section{Genus Hermadion Kinberg.}

\section{Hermadion rouchi Gravier.}

Gravier (1911), p. 82, pl. III, figs. 33, 34; pl. IV, figs. 45-51; pl. VII, fig. 74.

Harmothoe crosetensis Ehlers (1913), p. 442, pl. XXVII, figs. 1-4 (nec Lagisca crosetensis M(cIntosh).*

$$
\text { (Plate 7, figs. 43-47.) }
$$

Of the ten specimens which I attribute to the species, two, measuring $18 \mathrm{~mm}$. with 27 segments, and $22 \mathrm{inm}$. with 38 , are closely similar to Ehlers coloured figure (fig. 1) of the worm to which he applies the name "Harmothse crosetensis McI." That is, the elytra are alternately darker and very pale - in the case of his specimens, gray in colour, in mine, olive-green or olive-brown in the two individuals respectively. The dorsal chrtæ are golden, long, and overarch the dorsum and even inter-digitate with those of the other side. In these and practically all other details of structure my specimens agree with the account given by Ehlers. But these features - especially the great length and the position of the dorsal chætæ - do not agree with the description and figures of Lagisca crosetensis given by McIntosh, whose figure of the entire worm shows, on the contrary, quite short chætæ, not overarching the dorsum in the slightest degree.

Moreover, Ehlers states that the ventral chæta are not bidentate which is a characteristically developed feature of $L$. crosetensis ; indeed the only feature in which the worm agrees with that of MicIntosh is that the elytra bear sharply-conical tubercles.

At first I was content to accept the identification by the most experienced European student of exotic Annelids, till I came to examine another lot of worms of larger size than the two above mentioned; these are without pigment and agree in all essential features with Gravier's account of Hermadion rouchi.

I then returned to these smaller specimens of what I had thouglit were Harmothoe crosetensis, and after a careful comparison of organ with organ of the two lots, I found that they presented such a close agreement as to amount to identity, so that I came to the conclusion that the smaller coloured individuals are the young of Hermadion rouchi.

* Whether the species briefly described by Willey $(1902$, p. 266) belongs to IcIntosh's species or to Gravier's 1 am. unable to decirle, but the sketch (pl. xliii, fig. 3) of the tip of the ventral elata inclines me to think that he had 11 . roueli before hin, cas it differs from the figure given by MeIntosh for his spiecies and seoms to have stout spines on the first frill; but the figure is rather indistinet in this respect. 
In order to establish the above conclusion, I will give the measurements of the wol'ms.

A.- The small worms, witl coloured elytra.-

(1) Nearly complete, with green elytra; $18 \mathrm{~mm}$. in lengtl, with 28 segments; width at the 7-12th segment is $4 \mathrm{~mm}$. over the body, measured ventrally; $6 \mathrm{~mm}$. over the neuropod, and $9 \mathrm{~mm}$. over the chætæ. The dorsum is marked with dark-green narrow transverse bars at the sides and with a thin green line on each segment, crossing from side to side. No information as to the locality.

(2) Is similarly coloured, though with brown; the posterior end, after the 28th segment, is regenerated, with 9-10 minute segments. The length is $22 \mathrm{~mm}$. for these 38 segments. This individual is rather soft; the dorsal chætæ do not meet their fellows, though they overarch the back. (Station 12.)

B.-Uncoloured individuals, i.e., the elytra are without pigment.-

(3) Length, $23.5 \mathrm{~mm}$. with 39 segments ; width $7 \mathrm{~mm}$. over neuropods. (From Station 10.)

(4) About the same size, though imperfect. Quite similar to number 3. No data as to locality.

The remainder were taken together at Station $1 .-$

(5) $28 \mathrm{~mm}$. with 41 segments with 7 segments exposed behind the elytra.

(6) $32 \mathrm{~mm}$. for 42 segments.

(7) $40 \mathrm{~mm}$. with 44 segments.

(8) $51 \mathrm{~mm}$. with 45 segments, last 10 segments incovered.

(9) Imperfect, but intermediate in size.

(10) The largest is $81 \mathrm{~mm}$. with 46 segments, of which the last 13 are uncovered.

We have here a gradinal increase in length with segments added at the hinder end ; and there seems no doubt that, since all agree in their structural details, we are dealing with a single species at different ages. Variation in colour now is so well known, as for instance in $H$. spinosa, that little reliance can be given or placed on that as a specific character.

I may add that the largest of the three specimens contained in the French collec. tion measured only $42 \mathrm{~mm}$. with 42 segments, while the two smaller ones were about $24 \mathrm{~mm}$. in length. Gravier states that in his specimens the dorsum is unpigmerted, but in each segment there are two narrow cross-bars of dark violet; he also notes that pigmentation is less marked in the larger than in the two others.

It will be well to give in some detail some facts about the specimens from Commonwealth Bay. 
The largest individual is $81 \mathrm{~mm}$. long; the width of the body measured ventrally in the region of segments 12-18, is $12 \mathrm{~mm}$.; it is $19 \mathrm{~mm}$. over the neuropods ; and $28 \mathrm{~mm}$. including the ventral chxtæ. The number of segments is 46 . The elytra are uncolonred; the dorsal body wall is without pigment, being flesh-coloured, except for a band of pale violet on the tentacles and cirri below the subterminal swelling, and a small violet or brownish patch on the anterior face of the dorsal cirrophores.

In the smaller coloured specimens, the tips of the acicular processes are also violet.

The species has, as Gravier remarks, a quite characteristic appearance, owing to the very long, straight dorsal chætæ of beautiful golden colour which radiate in all directions from the upper surface of the large notopods, somc of which overarch the elytra.

The anterior elytra, as well as those at the posterior end of the series, overlap right and left, but in the middle region of the body, they leave the dorsum exposed, while some dozen segments lie behind the last elytra.

The account given by Gravier fits the present specimens so completely that it is only necessary to note one point in which they appear to differ from those described by him.

Of the dorsal chætæ, Gravier states that the majority exhibit no ornamentation, though some of the lower ones of a bundle are traversed by a few cross-markings, and present indications of marginal denticulations (sec his pl. IV, fig. 48).

Fhlers, in his figure (pl. XXVII, fig. 4) shows a series of pectinated frills crossing the chætæ from side to side. I agree with him, though his figure shows them rather too widely separated from one another and is so drawn as to imply that they have a spiral course.

I find that in the younger individuals there is a fairly long smooth apex with a blunt point (figs. $43,44,45$ ), which in some of the older specimens, especially in the chætæ in the uppermost part of the bundle, is frequently worn away, so that there is no smooth region and the tip is almost truncated. Below this smooth region there follows a series of about 30 closely set transverse pectinated frills which nearly encircle the chæta ; each consists of minute teeth, and the frilled region occupies about half the length of the exposed portion of the chæta, or even more in the shorter bristles of the lower part of the bundle.

While speaking of these dorsal chætæ, I may refer to a point on which I must differ from Ehlers. In those smaller individuals which so closely resemble the specimens described by him as $H$. crosetensis in all other respects, I find none of the long slender hair-like bristles which he describes and figures as occurring in some of his specimens. On p. 443, he describes the notopod as bearing in addition to and intermingling with the stout yellow chætæ "sehr langen und haar-feinen Borsten," which project over the 
dorsum and may even interdigitate with those of the opposite side (pl. XXVII, fig. 3). He says further (p. 444) that although they are not present in all individuals, he has found them in both small and large specimens, and he suggests that their presence may bear some relation to sexual maturity. I have examined several parapods taken from both large and small specimens with the especial object of finding these fine capillary bristles. Occasionally some of the chætix may be seen edgewise and so appenr thinner than when seen on the flat surface, and frills are then seen to project from both edges giving an appearance somewhat like Ehlers's figure. But I do not find such difference in length as he found. Gravier does not mention their occurrence in his specimens, and on the presumption that we are dealing with the same species, this is the only feature in which ours really differ from those examined by Ehlers. I may add that McIntosh does not mention such bristles in his account of $L$. crosetensis.

So far, then, as the present specimens are concerned, all the dorsal cliætæ are alike in structure, though they differ in length ; those in the lower part of the bundle being about half the length of those in the upper part.

The same difference in size exists amongst the ventral chætæ. The ventral chætæ (figs. 46, 47) which in L. crosetensis, McIntosh states are " not furnished with long spines, and have a distinct sub-apical tooth;" have in the present case, as Gravier has figured (pl. IV, fig. 49) certain pronounced spines or teeth amongst the upper frills, which are absent in the lower frills. In some chætæ two such spines occur on one side and one on the other; in other cases, two on each side. The frilled region is long, consisting of about 20 frills which are discontinuous in the distal region, but become continuous over the greater part. Ehlers says little about the ventral chrtæ, except to state that the apex is simple. Why then should he refer it to the species $L$. crosetensis?

However, in Hermadion rouchi, although most of the ventrals have a simple apex, with no sign of a sub-apical tooth, there is occasionally a sub-apical " step," which seems to indicate a tooth that has been worn away. And Gravier states that in some of his specimens he found a tooth.

More than one zoologist has in recent years commented upon the difficulty of distinguishing between the two genera, Lagisca Malmgren and Hermadion Kinberg, as well as upon the question of the distinction between them and the genus Harmotho? Kinberg. Most writers accept the last genus in an extended sense as including several of Malmgren's sub-genera, though Professor McIntosh still retains most of the latter; and in his splendid monograph of the British Annelids, published by the Ray Society, these names are even used as generic.

I need not discuss this matter further as Baron de St. Joseph (1888, p. 150) has given the history of these names. It was Willey (1902), I believe, who first drew attention to the resemblance between Lagisca and Hermadion. And Fauvel (1916) has recently summarised the main points in the controversy raised by him and also. discussed by Gravier (1911). Fauvel concludes (p. 426) that Hermadion is distinguish-83892-u 
able from Lagisea by the absence of the prostomial frontal lobes or "peaks ;" the dorsal chrtio are generally smooth or very feebly striated; the ventrals unidentate in even in the young. Therefore, he believes that to mnite the two genera would be premature.

But is the statement of differences altogether correct? For Ehlers describes the presence of these "peaks" to two species, Hermadion ambiguum and H. molluseum $(1897, p .16)$; they are present in $H$. rouchi. It is true that these peaks are absent in the type species, $H$. magalhaensis Kinberg, as well as in his $H$. longicirratum and in $H$. kerguelensis McIntosh (1885), which according to Fauvel are synonymous. On the other hand, although typically present in Lagisca, they may be absent (see L. jeffreysii McIntosh, for instance). It seems as if there ought to be a great deal of shifting of these species from one genus to the other, if we accept Fauvel's dictum.

As to the dorsal chætæ, it appears that in young stages of $H$. rouchi, at any rate, as well as in other species, the dorsal chætæ do have striations, that is fine pectinated frills or combs, whereas in the older chætæ, the longer ones, they are less distinctly marked. It may be that this is due to wearing away of the frills owing to use. And a similar explanation may perhaps be given of the absence of a sub-apical tooth in the ventral chætæ. For although this is generally absent, yet it does occur in the shorter younger chætæ, or in others its place is taken by a "step," in this position.

It appears then that the distinctions between the two genera Lagisca and Hermadion do not exist. They are identical.

A further question has been raised as to whether or not there is any real distinction between the genera Hermadion and Harroths. If we review the various oligomeric forms, it appears that Harmolhoe has its dorsum entirely covered by the elytra; that none of the posterior segments remain uncovered, or at most only two or three. Whereas in Hermadion, several, up to a dozen or more, are exposed in large forms. It is true that Willey has ascribed to Harmothoe spinosa an individual which he regards as a variety and calls "lagiscoides," partly because of the conical tubercles on the elytra, and this one individual has 6 naked segments at the hinder end. But more information. $i_{S}$ needed to convince me that the individual is a variety of Harmothos spinosa.

Yet, because of this variety, Willey proposed an addition to the generic diagnosis of IIarmothse, which would eliminate the only remaining constant difference between it and Hermadion, and so comes to the conclusion that all threegenera are synonymous.

For the present, I am of opinion that it wonld be well to retain the distinction between Harmothse and Hermadion.

\section{Localities.-}

Commonwealth Bay, Station 1, 350-400 fathoms (six, colourless).

Station 10, 325 fathoms (one juvenile, colourless).

Station 12, 110 fathoms (one juvenile, coloured).

No data (one coloured and one uncoloured, juvenile).

Distribution.-Marguerite Bay, île Adelaide (Gravier), Kaiser Wilhelm II Land (Ehlers). 
Family PHYLLODOCIDE.

Sub-family Phyllodocinæ.

Genus Phyldodoce Savigny.

Phyllodoce Madeirensis Langerhans.

Langerhans (1880), p. 307, pl. XVII, fig. 44.

Willey (1902), p. 270, pl. XLII, fig. 5 ; pl. XLIV, fig. 7.

Ehlers (1897), p. 25.

Ehlers (1901), p. 72.

Ehlers (1913), p. 453.

Four individuals of this widely distributed species were obtained in dredgings in 25-120 fathoms. These are larger than the type, which only reached a length of $70 \mathrm{~mm}$., with 105 segments, and than those described from the Antarctic by Willey. The present specimens attain a length of $190 \mathrm{~mm}$., with nearly 300 segments. The greatest width of the body is $2.5 \mathrm{~mm}$. to $3 \mathrm{~mm}$., and over the parapods $6 \mathrm{~mm}$., and does not vary much throughout the length.

The colour, which Langerhans found to be green in life, is in the preserved worms in some cases pale brown, with the dorsal cirri rather darker; in other individuals pale grey, which owing to iridescence appears silvery, with pink cirri-a pale but decided pink. This one is mature, and contains eggs.

The tentacular cirri are arranged, as Willey has described, and as Ehlers has confirmed; the longest reaches to the 10th or 12th segment, the second ventral is about half this length. Although Langerhans wrongly allocates these cirri in his text, yet his figure seems to show their distribution quite clearly, and is more informative than Willey's figure.

The pharyngeal papillæ have the characteristic arrangement, which is very evident in one of our specimens, in which the pharynx is everted.

Localities.-

Station B, 25 fathoms.

Station D, 45-50 fathoms. Distended with eggs.

Station 8, 120 fathoms.

Distribution.-Madeira (Langerhans), Juan Fernandez, Sonth Georgia, Kaiser Wilhelm II Land (Ehlers), Cape Adare (Willey).

Remarks.- This is rather a remarkable range, and the much larger dimensions of these Antarctic specimens raises the question as to the specific identity, which is mainly upheld by the characteristic arrangement of the pharyngeal papillæ. Another species, $P$. medipapillata, described by Moore (1909, p. 237), also has the median row of 4 or 5 papille, with six lateral rows on each side, containing 9 in the ventral and 12 in the dorsal rows. This occurs on the coast of California. 
- Genus Eulalia Savigny.

Eulalia charcoti Gravier.

Gravier (1911), p. 57, pl. I, figs. 14-16 ; pl. II, figs. 17, 18.

Eulatia charcoti lives in comparatively deep water, our specimens coming from depths of 110-318 fathoms, and Gravier's from 210 fathoms (approx.).

The preserved specimens have a dark greenish-blue body with brownish-green cirri ; the body is highly iridescent, and in one individual the effect produced is a bronzy green colour.

Two of them have a dark blue band along the middle third of the dorsum, with a green iridescence; the lateral thirds being russet brown, and the cirri olive green. The whole effect is very beautiful. Gravier states that in life the worm is " emerald green with blue iridescence." There is but little to add to his account.

The longest of our specimens measures $150 \mathrm{~mm}$. by $6 \mathrm{~mm}$. across the body, which is larger than Gravier's largest. The longest of the tentacular cirri, belonging to the second segment, is $8 \mathrm{~mm}$., and reaches to the 23rd segment, the next one is only $5 \mathrm{~mm}$. long, and reaches to the $15 \mathrm{th}$; the others are about half the length of the latter. These measurements are taken from a specimen $95 \mathrm{~mm}$. long, with a diameter of body $5 \mathrm{~mm}$.

The pharynx is everted in one individual, and shows the characteristic arrangement of the papilla, unusual in the genus, namely, six longitudinal rows of curved brown-edged papillæ, united basally by a broad continuous band of smaller rounded ones, and distally by a girdle of similar papillæ. There are about 50 small close-set papillæ at the entrance-an unusually large number.

\section{Localities.-}

Station 2, 318 fathoms (one).

Station 3, 157 fathoms (one).

Station 8, 120 fathoms (four).

Station 12, 110 fathoms (one).

Distribution.-Admiralty Bay, South Shetlands, in 420 metres (approx. 210 fathoms), (Gravier).

\section{Sub-genus pterocirrus Claparède.}

Eulalia (Pterocirrus) magalhanesis. Kinberg.

Kinberg (1865), p. 241.

Ehlers (1901), p. 73, pl. VIII, figs. 1-8.

Gravier (1906), p. 25.

Ehlers (1912), p. 13.

Gravier (1911), p. 56, pl. I, figs. 12, 13.

Fauvel (1919), p. 364 (gives several synonyms). 
An imperfect individual, consisting of the anterior end of abont 65 segments, appears to belong to this species. It measures $20 \mathrm{mun}$. in length and $2 \cdot \tilde{5} \mathrm{nnm}$. in width.

Most of the cirri are broken ; the colour is yellowish brown, with dark greenishblue patches, more or less extensive, irregular in shape and size, arranged along the dorsum ; they may be due to post-mortem changes.

Of the tentacular cirri only one, on the left side, and two on the right, remain. But the general agreement of the head, the parapod and the chrte, with the account given by Ehlers, inclines me to place the worm in this well-known Sub-antarctic species.

Locality :-

Macquarie Island, rock pool.

Distribution (In the Antarctic and Sub-antarctic regions).--Magellan region (Kinberg), Fuegia, Chilian coast, Kerguelen, Kaiser Wilhelm II Land, Coulman Island (Ehlers), Biscoe Bay, Petermann (Gravier).

\section{Eulalia (Pterocirrus) hunteri* $s p$. nov.}

(Plate 7, figs. 48-52.)

The single individual is complete; it measures $165 \mathrm{~mm}$. in length, by $2.25 \mathrm{~mm}$. over the body, and $6.5 \mathrm{~mm}$. over the dorsal cirri, which are directed outwards. Anteriorly the diameter of the body is but $1 \mathrm{~mm}$.; the greatest breadth is about $20 \mathrm{~mm}$. from this end, and is retained for rather more than one-half the total length, whence the body tapers gradually. This breadth of body is equal to $4 \frac{1}{2}$ segments.

The colour of the body is flesh-pink, with a pair of very dark blue, nearly black, irregularly quadrate spots on each seginent about midway between the mid-dorsal line and the lateral margin (fig. 48). These spots commence at the 9th segment. In the hinder quarter of the worm they extend medially till they meet, so that these segments are crossed by a series of dark bands.

The dorsal and ventral cirri are yellowish ; the ventral surface is of the same colour as the ground tint of the dorsum.

The body is convex dorsally, flat ventrally; the parapods are short, and the dorsal cirrophore is close to the body. The dorsal cirri are of considerable size, nearly as long as the body breadth, and are not relatively shorter on the anterior segments.

The prostomium is colourless, its breadth is rather greater than the length (fig. 49), and a slight notch on the posterior border, and also at the level of the insertion of the tentacles, gives it a trefoil shape.

* I take this opportunity of associating with this handsome annelid the name of Mr. J. G. Hunter, the able biologiak of the Expedition, 
The eyes are brown; the median tentacle springs from the dorsal surface in front of the level of the eyes ; it is more slender than the anterior tentacles, and about as long as the length of the prostomium. The two pairs of anterior tentacles have the usual position and shape, and are shorter than the median.

The first segment is distinct dorsally, behind the prostomium, and is of the same widtl. It bears on each side one comparatively short tentacular cirrus, which has the same form as the tentacles, but is stouter. The second segment carries two tentacular cirri on each side, the dorsal of which is sub-cylindrical and long, while the ventral is shorter, wide and distinctly foliaccous, produced into a short filamentous point. . It is longer than the normal dorsal cirrus, to which, however, it bears a resemblance.

The third segment bears a long sub-cylindrical dorsal tentacular cirrus, longer than that of the preceding segment; below it is the chretigerous lobe and a small foliaceous ventral cirrus.

These long tentacular cirri arc not, in reality, circular in section, but more or less compressed. The longest of them reaches to the 15 th segment; it is $2.25 \mathrm{~mm}$. in length. It may be noticed that these anterior segments are shorter than those that follow, the increase in length being gradual.

'The parapods (fig. 50) are short, with the anterior lip longer than the posterior. The foliaceous dorsal cirrus is broad, as wide as its length, with an asymmetrically situated apex; the cirrophore is close to the body wall. The ventral cirrus is oval, not pointed, about as long as the chrtigerous lobe.

The chrtæ (fig. 51). The shaft is a great deal wider than the appendix, and of a much higher degree of refringency, so that at the junction between the two there is a very marked transition when viewed under the microscope. The articular cup is strongly "heterogomph" and, as usual in the family, is very narrow; one lip is very short, the other is produced into a long curved claw-like structure, both are smooth, and present no striations. The appendix is relatively short; its proximal end is narrow, but soon acquires its full breadth, and then rather rapidly dwindles, to be prolonged into a very fine distal portion. It is very thin even in the lower portion, and is obliquely striated along its whole length; and its concave edge is faintly but distinctly denticulate.

The pharynx was exposed by dissection; the buccal region extends through 25 segments, and the pharynx occupies nine more, i.e., its hinder cnd reaches to the 42 nd. At its entrance are 16 small conical papillo. The buccal cavity is lined uniformly with closely set, round-topped, nearly cylindrical papilla, slightly narrower at the base than at the apex, and about 3 times as high as broad (fig. 52). They are practically of uniform size and shape throughout. In the everted condition the pharynx, therefore, would be said to be covered with these papillo. 


\section{Locality.-}

Commonwealth Bay, Station 12, 110 fathoms.

Remarks.-It agrees with Eulalia magalhansis Kinberg, in the form of the head and in the position of the median tentacle ; but differs from it in the arrangement and length of the tentacular cirri, in the shape of the dorsal cirri and of the parapods, and especially in the form of the clictx. The marked ungulation of the articular cup recalls that figured by Fhlers (1904, pl. II, fig. 9), for E. microphylla Schmarda, from New Zealand, in which, however, it is much less pronounced, and which differs in other respects of course.

\section{Eulalia (Pterocirrus) meleani, * $s p . n o v$.}

$$
\text { (Plate 7, figs. 52-57.) }
$$

Two specimens in the collection appear to be new. 'The one studicd in detail measures $45 \mathrm{~mm}$. in length, with 115 segments. Tlie breadth of the body, which is equal to the length of six segments, is $2.25 \mathrm{~mm}$., and over thc parapods $4 \mathrm{~mm}$. The peristomium is $1.5 \mathrm{~mm}$. across, and the body gradually widens till at about one-quarter of the body length it attains $2.25 \mathrm{~mm}$. in width; this is retained for about another quarter, when the body commences to taper.

In the second individual the plarynx is everted, and the body is a good deal contracted anteriorly; this contains 120 segments with a small regenerated region. Its length is $32 \mathrm{~mm}$., its greatest width $4.25 \mathrm{~mm}$.

The colour of the body is a uniform pale brown with a dull greenish-yellow cirri, which when pressed back over the body reach nearly to the middle line. Those of tle anterior segments are not mucl smaller than the rest, which are practically uniform in size.

The prostomium (fig. 53) is broader than long, trefoil slaped with a sliglt notch posteriorly. The eyes are large, and separated from one anothcr by a space rather greater than their diameter. The median tentacle arises far back, between the eyes, and is thus close to the linder margin ; it is a good deal longer than the prostomium. The lateral tentacles arise in the usual position; they have the shape of a long cone, constricted at the base with the apex.produced to a point.

The tentacles and cirri are quite pale, and possibly are yellowish in life.

The first and second segments are distinct dorsally, the longest tentacular cirrus reaches to the 14th segment, the other three are about half this length. The three upper cirri are circular in section, but the ventral cirrus of the second segment is flattened from in front backwards, higher than it is thick, so as to be foliaceous. Its apex is produced into a longish filament.

* I wish to associate with this animal the name of Dr. A. L. IcLean, who did such useful serrice in collecting at winter quarters. 
The parapods (fig. 54) are very short and rather high, the foliaceous dorsal cirrus is long and narrow; its length is more than twice its width; its apex is symmetrically pointed, its base is short and springs from the chrtigerous lobe close to the body. The ventral cirrus is comparatively large and of similar shape, longer than the chrtigerous lobe.

The chætæ (figs. 55, 56) are comparatively few in number; the lip of the articular cup is finely serrated on one side, smooth on the other; and the two lips are approximately of equal height; the appendix is long, narrow, straight, flexible and tapers gradually to a fine point; its edge is finely serrated.

The pharyngeal apparatus was everted in the larger of the two specimens, though the buccal membrane or pharyngeal sheath is ruptured at its base. The length of the pharynx is $15 \mathrm{~mm}$., with a diameter of $3 \mathrm{~mm}$. at its anterior end. The aperture is surrounded by 24 rather large papillæ, set as usual at the ends of ridges leading into the interior. The buccal membrane is uniformly covered with closely-set unequal, flattened, club-shaped papillæ, giving it a velvety appearance (fig. 57). They are much smaller than those of the preceding species.

From a study of the other specimen it appears that the intestine commences at about the 34th segment, so that the buccal and pharyngeal regions together must be $10 \mathrm{~mm}$. in length.

\section{Locality.-}

Commonwealth Bay, Station 1, 350-400 fathoms.

Remarks.-I suspected that this worm was E. magalhaensis, the only specimen of the genus hitherto recorded from these latitudes, but from it the present worm differs in the larger eyes, in the position of the median tentacle ; in the much greater length of the tentacular cirri; in the form of the appendix, and in the character of the articular cup; and in the number and shape of the pharyngeal papillæ.

\section{Genus Eteone Savigny. \\ Eteone Reyt Gravier.}

Gravier (1906), p. 26, pl. III, figs. 24-26; (1911), p. 60.

Ehlers (1913), p. 457.

A single individual of this small Phyllococid was found on a slide on which I had mounted some Syllids collected in Commonwealth Bay.

It is but $5 \mathrm{~mm}$. long, and consists of head, 26 chætigerous segments and the anal segment.

I find that the prostomium differs from Gravier's figure in that it is produced forwards as a narrower plate than the basal oculiferous region. This I take it is "what Ehlers means when he says that his specimen has a "spatelartig" prostomium. 
The absence of any dorsal cirrus above the first chretigerous lobe serves to differentiate the species.

The dorsal cirri along the middle and hinder portions of the hody are coloured reddish brown by little spots of pigment, and similar though smaller spots occur in groups along the back.

\section{Locality.-}

Commonwealth Bay. No data.

Distribution.-Port Charcot (Gravier), Kaiser Wilhelm II Land (Ehlers).

\section{Sub-family LopadorhyNChiNæ. \\ Genus Pelagobia Greef. \\ Pelagobia viguieri Gravier.}

Gravier (1911), p. 62, pl. II, figs. 22-25.

(Plate 7, figs. 58-60.)

Numerous individuals of this small pelagic worm were obtained in tow-netting in January, 1914, in depths from 45 to 100 fathoms, when the water was far below freezing point. One vial is marked "Temp.- $0.5^{\circ}$ C." ; another "Partly ice." Mixed with them was Tomopteris septentrionalis.

The length varies from 5-12 mm.; the head is followed by $21-25$ segments, the larger ones being sexually mature, containing eggs or.sperm morulæ.

Gravier's account, founded on only three specimens, agrees precisely with the present worms, but for one apparent omission. He has overlooked the existence in the long metastomial cirri of a chitinous supporting axis.

He correctly describes the first segment, which immediately follows the " head," as possessing on each side a very long dorsal and ventral cirrus, separated by a small bundle of compound chrtæ, such as occur throughout the worm. Each cirrus presents a swollen base, and has a much thickened cuticle on its posterior face (figs. 59-60). This cirrus is traversed nearly throughout its length by a delicate chitinous aciculum or thread of chitin. It starts at the apex of the cirrus, and just before the swelling is reached it tapers to a very fine point.

This axial support is so evident in specimens mounted in glycerine, as well as in balsam, that it is astonishing that no mention of it is made by Gravier.

Locality.- -

Commonwealth Bay, 45 faths., 50 faths., 100 faths.

Distribution.-Lat. $69^{\circ} 15^{\prime}$ South : long. $108^{\circ} 5^{\prime}$ West, at a depth of 950 metres. 983892-H 
Remarks.-Gravicr points out certain differences that exist between his species and $P$. longicirrata Grecf. Unfortunately I have not access to Grecf's paper, as the volume is missing from my series of the Zeit. f. Wiss. Zool. And, although the specics has becn recorded from most of the Antarctic expeditions no details or figures are published that cnable me to judge of Gravicr's statements in this respect.

The only figure relating to the spccies, which is available to me, is that given by Sonthern (1909, pl. I, fig. '1) of the chæta; and his statement on p. 2, that the appendix of all the chaetæ has " on the posterior side a delicate wing-like expansion." This is certainly not present in the species before me, and, moreover, the length of the appendix is longer and slenderer than it is in that figurc, and is in entire agreement with Gravier's figure.

\section{Family ALCTOPIDR.}

Genus Vanadis Greef.

Vanadis antarctica McIntosh.

Alciopa antarctica: McIntosh (1885), p. 175, pl. XXVIII; figs. 2-4; pl. XXXII, fig 12.

Vanadis antarctica, Apstein (1890. p. 543 (not seen).

$V$. antarctica, Willey (1902), p. 271, pl. XIIV, fig. 8; pl. XLVI, figs. 1, 2.

?Alciopa antarctica, Gravier (1911), p. 65, pl. II, fig. 26; pl. III, fig. 28, 29; p]. IV, fig. 38 .

V. antarctica, Ehlers (1913), p. 466.

$$
\text { (Plate 8, figs. 61-63.) }
$$

My excuse for describing once again this Antarctic species is that Gravier has thrown doubts on its generic position, and that the previous accounts are imperfect in some respects.

The material obtained consists of two specimens, a male and a female, which were captured on the surface of the sea by Dr. A. L. McLean; and some smaller individuals from 45 fathoms.

Dr. McLean notes that they are "transparent, mottled with brown." The female is entire, measures $135 \mathrm{~mm}$. in length, its greatest breadth is $5 \mathrm{~mm}$., at about mid-body. There are 93 segments, followed by a short regenerated region, $4 \mathrm{~mm}$. in length, of very small segments.

The prostomium is $3 \mathrm{~mm}$. across, and the anterior part of the body is very narrow, only $1.75 \mathrm{~mm}$., the head and this narrow region, or " neck," occupy a length of $11 \mathrm{~mm}$. 
The dorsal surface of the head and neck is pale brown; the rest of the body is of the same tint, with darker brown markings at the base of each parapod, both above and below; at irregular intervals along the body this deeper tint extends furtler over the surface, both dorsally and ventrally, forming larger and smaller areas, which nearly meet on the dorsal surface.

The male is imperfect, consisting of head and 56 segments, with a length of $65 \mathrm{~mm}$. As Gravier has pointed out, the glands below the parapods are much better developed than in the female, and I note a series of segmental white marks along the median ventral line which are better developed in the hinder part of the fragment than anteriorly. These are not present in the female.

'The anatomy of the worm agrees both with the account given by Willey and the more complete one by Gravier, except that the latter states that the colour of the specimens gathered by the French expedition, when alive was "vert jaunâtre," and that the spots were "vert épinard foncé."

There is, however, one important difference between these two accounts. Willey found, contrary to McIntosh's statement, that the bristles are "articulated," though he found it difficult to detect the articulations, till the bunch of chaetre was "sp ead out." Gravier, on the other hand, insists that they are "entire," and consequently expresses doubts as to the identity of Willey's specimens with that described by McIntosh and by himself. He enumerates three points of difference-namely, (1) in regard to the chaetr; (2) in regard to the absence in Willey's account of any description of the dorsal surface of the head; and (3), in regard to the papillæ at the entrance to the pharynx.

I will offer remarks on each of these points, and hope to clear up the doubts expressed by him.

(1) For some time I was unable to detect any articulation in the chacte. I followed Willey's advice to "spread them out," but failed at first to see any sign of jointing, even under high power. But chancing to shift the mirror of the microscope so that the light was no longer fully reflected, I noted an extremely faint and very oblique line crossing the very delicate and transparent bristles. This " jointing " is so unlike what one would expect from Willey's figure, the reproduction of which is coarse; it is so unlike the articulation that occurs, for instance, in Halodora, that it is easily overlooked. When viewed from the side the articulation, if one 'may call it so, has the appearance of a very oblique interruption in the chaetal substance, which does not seem to reach the edges in all cases; but most of the appendices have the appearance of being "spliced" to the shaft, that is, it and the shaft are obliquely cut across (fig. 62). Occasionally, one finds a chacta lying in a different plane, and the splicing appears to be more perfect and definite, where the distal appendix has its base sliced off on both sides to a point, and this fits into a V-shaped cut at the end of the shaft (fig. 63). 
Having once recognised the position of the articulations, one can see a bending of the bristles, forming an open angle, which might be taken for a merc "bend" till the existence of the articulation was ascertained.

Even when I liad satisfied myself of their existence, I found it very difficult to detect these articulations in spccimens mounted in glycerine jelly, even by the use of a high power, but it is easy to see them in fresh glycerine. I re-examined specimens mounted in glycerine, twelve months later, and saw the articulations quite clearly in every chaeta.

The length of the appendix is small, compared with the total length of the bristle. I had some difficulty in estimating what its length is, since the bristle is so long that it will not lie wholly in the field with an objective 3 and ocular 3 of Leitz, and a lower magnification is useless. By a fortunate chance a small air bubble occurred in the preparation about half way along one of the bristles, so that by making two camera drawings I was able to get practically the entire bristle, and was thus able to measure it. The total length is represented in the drawing by $570 \mathrm{~mm}$., and the appendix by $10 \mathrm{~mm}$. approximately, for its tip is so fine that under this magnification it is invisible. Roughly, one may say that the length of the appendix is about $\frac{-1}{60}$ of that of the total (fig. 61). It may be noted that McIntosh says that " none of the extremely attenuate tips are complete." So that there is no real contradiction between his account and that of Willey. It is probable that all the appendices had dropped off or been broken off in the specimen, as is the case in many of the chaetæ in those before us.

(2) The second point is explained, I think, by the fact that McIntosh had represented in his figure the head from the dorsal aspect, and Willey drew attention to the structure of the ventral aspect, in order to complete the description of the species, as McIntosh had not given an accurate figure of this surface.

(3) The third point is, I believe, due to an error in observation by Gravier limself. Willey states that in the everted pharynx the entrance is surrounded by twelve soft conical papillæ. In the specimen described by Gravier the pharynx was not everted; he states that it extends backwards as far as the 20th segment, where it is bent upon itself. He goes on to say (p. 68): "Le bord de l'orifice postérieur est froncó, mais ne présente pas ni papille definie, ni prolongements digitiformes."

Hc omits to mention the buccal region. Now, of course, the papillæ being at the entrance of the pharynx from the buccal region must be looked for, not at the posterior extremity, but at the anterior extremity of the pharynx when at rest inside the body.

I dissected the male individual and find that the buccal region is very short, extending to about the 5th or 6th segment, including the peristomium; then follow the long "trompe très musculeuse," which reaches to the 20th segment; then it bends upon itself and reaches forward to the 15th segment, where it enters the thin-walled intestine. On slitting open this apparatus I find at the antcrior extremity of the pharynx or "trompe" the series of papillæ described and figured by Willey. 
The weight of evidence, then, appears to be against Gravier's contention that this species belongs to the genus Alciopa. McIntosh had already noted the "short filiform cirrus at the end of the foot." Gravier hiniself recognises that it " approaches the genus Varadis" on this account, and points out that only in the absence of the prehensile organ at the entrance to the pharynx and in the form of the chaetre does it differ therefrom. As he himself considers the form of the chaeta as the "dominating" character of distinction, Apstein's contention and Willey's support of it are surely justified, and the only possibility left is that Gravier is dealing with a different speeies. from those obtained by the "Challenger," the "Southern Cross," and the "Aurora," which, I think, is not probable.

\section{Locality.-}

Commonwealth Bay, surface, and at 45 faths.

Distribution.-Antarctic Oceall, practically circumpolar (McIntosh, Ehlers, Gravier, Willey); Atlantic Ocean, near Ascension (Ehlers); North Pacific and Indian Oceans (Apstein).

\section{Family TOMOPTERID长.}

\section{Genus TOMOPTERIS Eschcholtz.}

Sub-genus Tomopteris Rosa.

TOMOPTERIS CARPENTERI Quatrefages.

Quatrefages (1865), vol. ii, p. 227, pl. XX, figs.1, 2.

? T. carpenteri, McIntosh (1885), p. 531.

(Plate 8, figs. 64-66.)

A very well-preserved, complete individual was obtained in the tow-net by Dr. NcLean in 45 fathoms of water among the pack ice; and four others, less well preserved, came from 50 fathoms, during January, 1914.

The description applies to the first-named specimen. It is $55 \mathrm{~mm}$. in length, with a maximum diameter of $13 \mathrm{~mm}$. over the parapods in the mid-body. It is $7 \mathrm{~mm}$. across the first pair. The total width gradually increases till the middle of the body, then decreases to the hinder end. The body itself measures $4 \mathrm{~mm}$. across, at about the middle, but is only $2 \cdot 25 \mathrm{~mm}$. at the neck, in front of the first parapod. There are 33 pairs of parapods, the last 2 or 3 being very small. The same number occurs in a less well-preserved specimen, which is only $3 \tilde{\mathrm{m}} \mathrm{m}$. in length by $8 \mathrm{~mm}$. over the feet.

The anterior parapods are short. 'They gradually increase in length up to the 6th, and this maximun length is retained till about the $14 \mathrm{tl}$, when they decrease.

The worm is opaque in the preserved state (in formaline). The eolour is pale brown with a darker band along the mid-dorsal and mid-ventral lines. In the shorter specimen there are two areas of deep brown.across the ventral surfaee of the body and 
parapods, extending over the anterior third and over the hinder third of the body. Whether these are post-mortem or not I cannot say. The head and posterior end as well as the middle third are quite pale.

There is no trace of a "tail."

The prostomial cormua (fig. 64) are carried on a very short, wide base. The anterior margin has no median notch, and the frilled membrane is continuons from side to side. The extremities of the cornua are gently curved backwards, and reach to the outer ends of the enlarged bases of the long cirri.

The ciliated epaulettes are very distinct, narrow, slightly curved, with the convexity mediad. They commence at the anterior margin and reach about halfway along the dorsal surface of the head, terminating in a depression of its surface. In a less well-preserved specimen the epaulettes assume a more or less triangular form, with the base external and one angle mediad, that of the left side especially resembles Quatrefages' figure (pl. XX, fig. 1).

The dorsal surface of the prostomium - that is, the middle region of the " head "is convex, and rather browner than the neighbouring region of the body; it is bounded laterally by a pair of deep, longitudinal depressions, which separate it from the cirrus bases on either side.

No eyes are visible in this individual; but they are present in the smallest specimen, which was stained and mounted in balsam.

There is no sign of the " first cirrus" which occurs in some species.

The "second cirrus" is at least $18 \mathrm{~mm}$. in length, and reaches to at least the 15th segment. It is very delicate, breaks easily on being manipulated. The cellular envelope is missing in the distal portion, and the protruding, very transparent chitinous axis is difficult to trace under a dissecting microscope. It is thus difficult to state exactly the length of this cirrus. But in the larger of the less well-preserved specimens the cirrus is seen to extend to the hinder end of the body; so that this may, I think, be regarded as its normal length. The base of the cirrus is nearly hemispher.cal, with a somewhat pointed apex externally, whence the cirrus arises. The longitudinal diameter of the base is about equal to its transverse, and this is greater than the width of the prostomium. The diameter of the "head" across the cirrus bases is 5.5 mm.

Between the base of the cirrus and the first pair of parapods the gap is longer than that separating the subsequent feet. The length of this gap or " neck" is equal to the diameter of the body at this point.

The distance separating the successive parapods is about half the basal length, but in the poorly-preserved specimen the fect are closer together.

At their greatest development the length of a parapod is greater than the width of the body, but at either end of the series this difference decreases. 
The dorsal ramus of the foot (fig. 66 ) is rather shorter than the ventral, and the two diverge at an angle which approaches $90^{\circ}$. Indeed, in less well-preserved specimens, this angle is a right angle. The end of each ramus is bluntly pointed and appears brown, especially in those cases in which the membrane has been torn away. 'The "pinnal membrane" is characteristically developed, and resembles that of T. nisseni Rosa. On the dorsal surface it commences on the base of the foot, some distance proximad of the bifurcation; its line of origin is undulating, as also is its margin. The membrane continues round the apex, and only ceases at the angle formed by the two rami. The arrangement of the ventral pinnal membrane is similar, but it is more extensive. It bears two "pinnal glands," which are termed by Rosa the "hyaline" and the "chromophil" glands." There is no "rosette." The species, therefore, belongs to Rosa's sub-genus Tomopteris.

The " hyaline" gland is capped by a dark orange or red brown mass of pigment, and is situated just dorsal of the apex of the ventral ramus. It makes its first appearance on the $3 \mathrm{rd}$ foot.

The "chromophil" gland (the "cupule" of Quatrefages) appears as a rounded glandular thickening, differing in texture, as in its pale buff colour, from the surrounding transparent membrane. These glands commence on the 5 th foot, and are recognisable as far back as the 20th, beyond which I am unable to detect them.

The two larger specimens are males, and the young testis is situated in the dorsal lobe of the foot, along the roof of its cavity.

Locality.-

Commonwealth Bay. Pack ice.

Distribution.-Antarctic Ocean, lat. $60^{\circ} 3^{\prime}$ South, long. $0^{\circ}$.60 (Quat.). Between Kerguelen and Macdonald Islands (McIntosh).

Remarks.-This species formed the basis of Quatrefages' account of the genus in his "Histoire Naturelle des Annelés," and his account has been repeated, though recast, by Rosa (1908, p. 312) in his useful monograph of the genus. Quatrefages' specimen had been collected during the voyage to the South Polar Regions of the Zelée (1837-1840), though it is not mentioned in the r. reports of that voyage. The specimen was imperfect, lacking the hinder end and the long cirri. It is described as being opaque and " maroon coloured" (which agrees probably with the present specimens). Owing to the imperfections of the type, I have deemed it worth while to enter pretty fully into detail, for the species has not been examined or reported upon since 1865 . Quatrefages, in his figure of the " head " (pl. XX, fig. 1) shows the epaulettes as triangular, and, as I have mentioned, it is so when the animal is ill preserved. The foot (Quat., fig. 2) is possibly somewhat distorted, as the angle made by the two rami is greater than it is in well-preserved material. Here, again, I

*Though the gland takes hrematoxylin very strongly, it is not noticeably affected by alum carmine, which I used. 
find that ill-preserved spccimcns arc more nearly like Quatrefages' figure. In short, the present specimens agrec precisely with his account of the spccies, whether under the description of the genus (p. 219) or of the species (p. 227).

'There is, I think, strong justification for McIntosh ascribing to this species thosc specimens that occurred in considerable numbers in the neighbourhood of Kcrguelen. It is true he gives no details whatever, and Rosa has suggestcd that pcrhaps he lad T. eschcholtzi Quat., before him. This occurs near the Cape of Good Hope, and the suggestion was, no doubt, warranted. But in view of the fact that $T$. carpenteri was originally found in the neighbourhood of Bouvet Island and now at almost the exact opposite quarter of the Antarctic seas there is no geographical ground for refusing to accept McIntosh's identification.

\section{Tonopteris SEPTE NTRIONALIS Quatrefages.}

Quatrefages (1865), vol. ii, p. 229.

Rosa (1908), p. 297, pl. XII, fig. 17.

T. (Johnstonella ) septentrionalis, Gravier (1911), p. 72 (full list of references).

About a dozen specimens of this bi-polar species were gathered by tow-netting during January, 1914, at depths from 45-100 fathoms. They vary in length from 5-15 mm.

Gravier has already pointed out that in his specimens the length of the peristomial cirri exceeds that given by Rosa, who states that they are about $\frac{2}{3}$ the body length. It appears possible that this varies with age, for $I$ find that in one that is $8 \mathrm{~mm}$. in length the cirri are longer than the body. The specimen was mounted, and the cirri fortunately lay directcd backwards. In one of $15 \mathrm{~mm}$. they are at least $10 \mathrm{~mm}$. long, and have every appearance of having been broken. Southern gives the length as from "onehalf to four-fifths" of the body length (1911, p. 21).

As previous observers have stated, the hyaline glands are difficult of detection in all the segments in which thcy occur. I find them in the first thrce parapods distinctly and in at least 12 of the subsequent parapods, though they are not readily visible ir all the feett of every specimen.

The cyes arc brown, rather far apart, and situated far forwards, just in front ) the bases of the cirri.

Surely it is by a lapsus calami that Gravier places this species in the sub-genus Johnstonella, for it has, according to the observations of Apstein, Rosa, and myself, neither rosette nor first cirrus nor tail; and Rosa himself places it in the sub-genus Tomopteris on this account.

\section{Localities.-}

Commonwealth Bay, 45 fathoms, 50 fathoms, 100 fathoms.

Distribution.-North Atlantic; Baltic; North Sca; S.W. Coast of Ireland (Southern); Pacific (Apstcin); lat. $69^{\circ} 15^{\prime}$ south, long. 105 $5^{\prime}$ west (Gravier). 


\section{Family NEREIDA.}

Genus Nereis Cuvier.

Nereis loxechini Kinberg.

Nicon loxechini, Kinberg (1865), No. 2, p. 178.

Nereis loxechini, Ehlers (1908), p. 73.

Nereis loxechini, Ehlers (1913), p. 497.

(Plate 8, figs. 67-75.)

This is evidently a rare worm, and the only species of Nersis (other than $N$. uncinata Ehlers) recorded from the Antarctic region. Up till 1908 it had not been met with since Kinberg's record of it at Magellan Strait. In that year Ehlers published a brief description of a small individual obtained from St. Paul's Island; the only one collected by the expedition. In his later memoir he records a larger specimen, measuring $77 \mathrm{~mm}$. by $6 \mathrm{~mm}$. across the body, and containing 86 segments, from Kaiser Wilhelm II Land. It was noted as being " red-brown in colour" when alive. Hé, however, added no new facts about the species.

As no figures have been published (unless they are contained in Theel's new, edition of K inberg's work, which I have not been able to consult), it seems desirable to. add another and more detailed illustrated account of the species.

Three specimens were gathered by the "Aurora," in depths from 157 to 325 fathoms; all are more or less imperfect. The most nearly complete individual has a length of $60 \mathrm{~mm}$. and a breadth of $6 \mathrm{~mm}$. over the parapods, and $5 \mathrm{~mm}$. over the body. anteriorly; thence it tapers, so that at about the middle of the body these measurements are 4 and $3 \mathrm{~mm}$. respectively.

This worm consists of 132 segments, and only lacks a few of the hindmost. Another fragment represents a larger individual; it consists of the head and 45 segments, and measures $40 \mathrm{~mm}$., with a breadth of $5 \mathrm{~mm}$. over the body, and $7 \mathrm{~mm}$. across the feet.

The third specimen is rather soft; it is $26 \mathrm{~mm}$. by $3 \mathrm{~mm}$. over the body, and $4 \mathrm{~mm}$. over the feet. The hinder end of the fragment, whose segments I did not count, is $1.25 \mathrm{~mm}$. across the body.

The dorsal surface is brown, more deeply tinted over the middle area, with a pale line across the anterior margin of each segment; the lateral areas are almost white ; the parapods are brown, with two glandular masses of greyish-brown at their bases. The tips of the ligules are similarly tinted.

The prostomium (fig. 67 ) is broader than long; the posterior oculiferous region is rather abruptly marked off from the narrower tentacular region in the well preserved specimen, but not so much in the less well preserved (fig. 68). The eyes are large, each with a well developed lens; the posterior eye is oval rather than circular, with the long 
axis slightly oblique to a transverse line; they faee upwards and baekwards. The anterior pair, of which only the upper half is visible from above in this specimen, faces forwards and outwards. The posterior pair is close to the hinder margin, the anterior separated from them by about the diameter of an eye.

The tentacles are about half the length of the prostomium in one case ; nearly equal to it in the less well preserved speeimen. The palps are broad and short, with a nearly spherical appendage, and do not reach further forwards than the tips of the tentaeles, or only slightly further.

Of the peristomial cirri, the longest, i.e., the anterior dorsal, reaches back to the 7 th or 9 th segment, and is from 8 to $10 \mathrm{~mm}$. in length; the next, antero-ventral, is about half this length, and the other two are successively shorter, the shortest being of the same length as the prostomium plus its tentacles.

Thc peristomium is rather longer than the first chætigerous segment and about equal to the second; it has a straight anterior margin.

The parapods are relatively short: and present a peculiarity that I do not remember seeing noted in other speeies. The posterior lip of the neuropod is produced outwards into an ovate process, very distinctly constricted at its base, and though normally directed outwards, is sometimes displaced backwards. It occupies the position of one of the foliaseous outgrowths characteristic of the Heteronereid stage of some species (fig. 69).

In the anterior feet, up to about the $22 \mathrm{nd}$, the upper ligule is bluntly pointed, no longer than the dorsal lip or " middle ligule." The lip of the ventral lobe is bluntly rounded and earries, as I have mentioned, the eurious appendage on its posterior face. The ventral ligule is rounded and shorter and broader than the ventral lip, and this seems to be a specific character (fig. 70).

Posteriorly, at or about the 34th foot (fig. 71), the upper ligule beeomes rather more pointed, as does also the middle ligule; the ventral ligule remains broadly rounded, and is even larger than anteriorly.

In the still more posterior feet (fig. 72) this ventral ligule is still more notiecable as a large rounded lobe, larger than any of the other lobes.

The ehaetæe are arranged as follow in the anterior feet:-

Dorsal bundle.-About 12-15 spinigerous homogomphs, with long slender appendix.

Ventral bundle.-(a) Supra-acieular group: 6-8 spinigerous lomogomphs, as above, together with 3-4 stout-shaftcd, brown, faleigerous licterogomphs with a shorter appendix.* (b) Sub-acicular group : A few spiniger lomogomplis and 16-18 hcterogomph faleigers with slender colourles shaft.

- The appendix is short only as compared with that of the homogomphs; it is longer than the usual short falciger. 
The brown, stout heterogomphs arc absent in the anterior fcet of the specimen from 157 fathoms. Is it a sexual mark ?

In the 20th and subsequent feet the number of these stout bristles is reduced to two.

The appendix of the heterogomphs (figs. 73,74 ) is knife-blade like, with long fine hairs along its edge. The tip is hooked, and from the end an oblique line indicates the margin of the "guard."

The pharyux is peculiar in having no paragnaths, either in the oral or in the maxillary divisions. The jaw (fig. 76) has sixteen rounded teeth, of which the five distals are concealed by the brown edge of the jaw, as it lies on its sidc.

\section{Locality.-}

Commonwealth Bay. Station 2, 318 fathoms (one); Station 3, 157 fathoms (one); Station 10, 325 fathoms (one).

Distribution.-York Bay, Magellan Strait (Kinberg) ; East of St. Paul Island, 367.3 fathoms; K. Wilhelm-II Land, 210 fathoms (Ehlers).*

\section{Nereis aUstralis Schmarda.}

Heteromereis australis Schmarda (1861), p. 101, pl. XXXI, fig. 242.

Platynereis magalhaenis Kinberg (1865), No. 2, p. 177.

Nereis Australis Benham (1909), p. 238, pl. IX, fig. 1.

For a full synonymy and literature see Benham (1909, p. 238) and Fauvel (1916, p. 484). The latter zoologist does not take the view put forward by myself that Schmarda's species is synonymous with Kinberg's. I have gone into this matter pretty fully in the above-mentioned article and I am still of opinion there expressed, although Ehlers does not seem to have noticed the discussion, and has expressed no opinion as to it in any of his recent works.

Specimens of the worm were collected at various spots on the Macquarje Island by Mr. H. Hamilton, to the number of sixty or more. He found jt in rock pools, \&c.; it appears, therefore, to be a littoral species. Some of the specimens are filled with reproductive cells, either male or female; but they exhibit no heteronereid changes.

One male, preserved in formalin, has pale orange-brown colour, brighter anteriorly, with grey feet.

One specimen, at least, is still within its tube composed of black sand particles and small stones. Gravier has describer such a sandy tube for $N$. magalhaensis.

A small individual, measuring $12 \mathrm{~mm}$. in length, has paragnaths only in compartments IV next the iaws; the rest of the buccal surface is barc.

*I have used Bell's estinate that one fathom is equal to 1.829 metres, as given in the "Discuvery" Report: footnote, p. 4. 
Locality.-

Macquarie Island (North End, Garden Bay, and West Coast).

Distribution.--Kerguelen, St. Paul, Magellan Region, Fuegia, Chili (Ehlers); Marion Island, Falkland Islands, Fernando Noronha (MeIntosh); New Zealand and its subantaretie outliers (Benham); Puerto Madryn (Gravier); Table Bay, South Afriea (Ramsay).

\section{Nereis kerguel ensis McIntosh.}

MeIntosh (1885), p. 225, pl. XXXV, figs. 10-12; pl. XVI A, figs. 17, 18.

Ehlers (1897), p. 65, pl. IV, figs. 81-93.

Gravier (1906), p. 29.

Ehlers (1907), p. 11.

Gravier (1911), p. 76.

Ehlers (1913), p. 495.

Ramsay (1914), p. 42.

Fauvel (1916), p. 433, with full bibliography.

Fanvel (1917), p. 203.

The present collection contained only two small speeimens, in eaeh of whieh the pharynx is protruded, allowing the charaeteristic arrangement of the paragnaths to be readily seen.

The species occurred with $N$. australis in rock pools, at low water.

i Locality.-

Maequarie Island.

Distribution.-Kerguelen (McIntosh, Ehlers); S. Georgia (Ehlers); S. Orkneys (Ramsay); Falkland Islands (Fauvel); Tasmania (Benham); New Zealand (Ehlers); S. Australia (Fauvel); Canary Islands, Mediterranean (Marenzeller); lle Booth Wandel, Petermann, Port Lockroy; Biscoe Bay, Admiralty Bay (Gravier).

\section{Family NEPHTHYDIDA. \\ Genus Nephthys Cuvier. \\ Nephthys macrura Schmarda.}

Schmarda (1861), p. 91.

N. virginis Kinberg* (1865), p. 239 ; Ehlers (1897), p. 19, pl. I, figs. 9-12.

N. trissophyllus, Grube (1877), p. 533; MeIntosh (1885), p. 159, pl. XXVI, figs. 1-5; pl. XXVII, figs. 1, 4; pl. XXX, fig. 8; pl. XIV ${ }_{\Lambda}$, figs. 9-11.

" hinberg writes "virginis" in his original account; Ehlers "virgini." 
N. macrura Ehlers (1904), p. 14.

N. macrura Ehlers(1908), p. 57; (1913), p. 451.

N. macrura Gravier (1911), p. 98.

N. macrura Benham (1915), p. 203, pl. XL, fig. 57.

$N$. macrura Fauvel (1916), p. 436, pl. VIII, figs. 1-3 (and adds $N$. protiosa Kinberg as a synonym).

In 1897 Ehlers, from a study of the original speeimens, showed that Grube's speeies is identical with that of Kinberg; and in his aceount of the New Zealand Annelids (1904) he further established, from an examination of the types, that Kinberg's species is synonymous with Schmarda's. He gave an extended and illustrated aceount of the species, whieh is widely spread over the subantaretie area. It is evidently very common, for the "Aurora" naturalists gathered some severty speeimens, varying in length from $14 \mathrm{~mm}$. up to $125 \mathrm{~mm}$., the latter with a diameter of $12 \mathrm{~mm}$. over the parapods.

The worms are labelled as being "flesh coloured" in life, as I know from observation of our local speeimens. In spirit, however, the dorsal surface becomes a pale brown and the parapods usually white.

The habitat extends from the shore-line, where it seems to be most abundant, to a depth of at least 157 fathoms, where it seems to attain its greatest size.

\section{Localities.-}

Boat Harbour-Shore : 2-4 fathoms ; 25 fathoms.

Station 3, 157 fathoms.

Station 12, 110 fathoms.

Distribution. - Sonth Chili (Sehmarda); Magellan Strait (Kinberg); Kergnelen (Grube, MeIntosh, Ehlers) : Heard Island (MeIntosh) ; Bouvet Island, New Zealand (Ehlers); Bass Strait(Benhain); South Shetlands (Gravier); Falkland Islands (Fauvel).

\section{Family AMPHINOMIDA:}

Genus Eurythoz Kinberg.

\section{Eurythoe complanata Pallas.}

E. pacifica Kinberg-MeIntosh (1885), p. 27, pl. II, figs. 3, 4; pl. III, fig. 2; pl. II A, fig. 13; pl. III A, figs. 5-9.

E. complanata Ehlers (1908), p. 38.

Ehlers* has shown that these two, as well as $\dot{E}$. alcyonia Savigny, are identical. and diseusses the history of the speeies. Fauvel $(1919$, p. 348) gives a list of the literature.

From the neighbourhood of Tasmania a young speeimen was obtained measuring $11 \mathrm{~mm}$. for 35 segments.

The distribution of the species is very wide, as it seems to ocenr in all seas and oceans.

* Ehlers, "Zur Kenntniss d. Ostafrikanischen Borstenwürmer" in Nachr. d. K. Gesell: d. Wiss. Giötingen. 1897, Heft. 2, p. 2 . 
Family EUNICIDÆ.

Sub-family Eunicina.

Genus Eunice Cuvier.*

Eunice tentaculata Quatrefages.

Quatrefages (1865), vol. I, p. 317.

E. pyonobranchiata NoIntosh (1885), p. 294, pl. XXXIX, figs. 13-15 ; pl. XXI A, figs, 4,5 .

E. pyenobranchiata Benhain (1915), p. 213, pl. XLI, figs. 79, 80.

Fauvel $(1917$, p. 209) has pointed out the resemblances in structure of these two species, and shows that they are identical. For other synonyms consult his article.

A single specimen of this Australasian worm was obtained by Professor Flynn (12th December, 1912).

\section{Locality.-}

Off Maria Island, Tasmania.

\section{Distribution.-}

Bass Strait (McIntosh, Benham), New Zealand (Benham), South Australia (Fauvel).

\section{Sub-family Lumbriconerein.e.}

Genus Lu Mbriconereis Blainville.

\section{LUMBRIĆONEREIS MAGALH AENSIS Kinberg.}

Kinberg (1864), p. 568.

- L. magalhaensis Grube (1877), p. 531.

L. kerguelensis Grube (1878), p. 14 (separate copy).

L. kerguelensis Gr., McIntosh (1885), p. 246, pl. XXXVI, figs. 16, 17 ; pl. XVII A, fig. 18; pl. XVIII A, figs. $2-4$.

L. magalhaєnsis Ehlers (1897), p. 74.

Ehlers (1901), p. 136.

Gravier (1906), p. 30.

Ehlers (1908), p. 99.

Gravier (1911), p. 78, pl. III, figs. 35,36 .

Ehlers (1913), p. 499.

The specimens before me agree almost exactly with McIntosh's account of L. kerguelensis Gr. Grube had tentatively assigned it to Kinberg's species, and Ehlers in 1897 , having had the opportunity of examining both the types, found that they are identical.

* Leiper (1908) has enumerated a series of names of annelid genera whieh are already "oceupied "; amongst otlers is E unite. But it is so well established amongst Zoologists, while the inseet to whieh it was originally applied is unknown to most of us, that no useful purpose would be served by disearling the name as now usually employod. 
The existence of an independent flange below the pseudo-articulation of the hooded hooks in the anterior feet seems to be a characteristic feature of the species, and in some of the lower clrætæ is a similar, but less developed flange on the convex side of the shaft.

There is, however, one point in which my specimens differ from tlie account given by McIntoslı. I do not find, in the posterior feet, hooded hooks like that figured by him on pl. XVII A, fig. 18; they resemble, on the other hand, that which he attributes to L. japonica, and figures on pl. XVIII A, fig. 1. Has an error crept into the explanation of the plates?

The buccal segment agrees with that figured by Gravier (pl. III, fig. 35), as representing the adult condition of the species.

The specimens in this collection number four ; one is imperfect and measures $80 \mathrm{~mm}$. by $3 \mathrm{~mm}$. This came from a depth of 325 fathoms. Of the other three from the Macquarie Island, one is mature and filled with eggs, rendering the body yellowish in colour ; it consists of 133 segments, and measures $65 \mathrm{~mm}$. by $2 \mathrm{~mm}$. The remaining two are more slender, dark purplish-brown (in formalin), with a green iridescence.

Localities.-

Commonwealth Bay, Station 10, 325 fathoms (one).

Macquarie Island, shore (three).

Distribution.-Kerguelen (Kinberg, Grube, McIntosh) ; Magellan Strait (Kinberg, Ehlers), Fuegia, South Georgia, Falkland Islands, Bouvet Island, K. WilhelmII Land (Ehlers); Ile Booth Wandel, Port Charcot, Petermann, Admiralty Bay, South Shetlands (Gravier).

\section{LUMBRICONEREIS MACQUARIENSIS, $s p . n o v$.}

(Plate 8, figs. 76-81.)

This anterior fragment of a small Lumbriconereid consists of a liead and 56 segments, and measures $25 \mathrm{~mm}$. by $1.25 \mathrm{~mm}$.

It is greyish in colour, non-iridescent. The specimen is not well preserved, and is rather soft.

The prostomium is dark bluish grey, nearly hemispherical, with a median ventral furrow (fig. 76). The peristomium is interrupted by a buccal process of the second segment, and this process is grooved in the middle line; furrows also exist, cutting into the edge of the lateral portions of the peristomium. Its appearance, in short, is like that figured by Gravier for the young of L. magalhaen sis, and also like Elllers' figure for $L$. sphocrocephala.

Were it not for further details, I should have referred it to the former species. 
The parapods arc very short, even anteriorly (fig. 77), with a rounded posterior lip, which does not project much beyond the antcrior lip ; the length of which scarcely exceeds its height. Posteriorly the feet arc even shorter (fig. 78). Fach is supported by a single uncoloured aciculum; the chætæe are very few; of the capilliforms (fig. 81) I see only one in the 8 th foot; there are no roots cmbedded in the foot, so that it is not a question of breakage and loss. In the 25 th foot there are none.

The hooded hooks are also few ; in the 8th only one is present; in the 25th therc are four; and at about the 45 th three only.

These hooded hooks are, for the most part, without any articulation (fig. 80); the hood is strongly striated, and at its proximal region its cdge is denticulated, some five or six distinct teeth being recognisable, at any rate in the 25 th foot.

In the various preparations of feet from different parts of the worm I met with only one articulated hook ; it presents below the articulation a "vcntral " independent flange (fig. 79), like that in L. magalhatnsis.

The upper jaws recall those of $L$. magalhaensis, but the lower jaiv plates are white, and resemble those of $L$. sphorocephala.

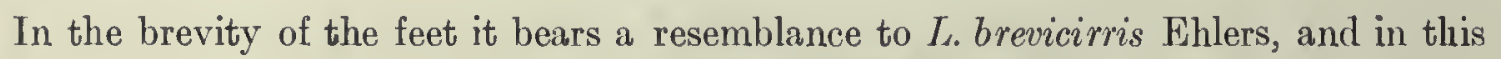
species, too, there are no articulated hooks, but the form of the hooks is very different, and the species differs from the present in other ways.

From L. sphcerocephala Schmarda, of which I have studied local examplcs, thc present species differs in having very much shorter feet; in the carly cessation of the capilliforms; in the lack of articulation in the hooks; in having a single colourless aciculum instead of three, of which one or more is dark brown; and in the structure of the upper jaw plates.

\section{Iocality.- \\ Macquarie Island.}

\section{Genus Ophryotrocha claparède and Metschnikoff.}

Ophryotrocha claParedi Studer.

Studer (1878), p. 119, pl. V, fig. 11.

Paractius notialis Ehlcrs (1908), p. 101, pl. XIV, figs. 1-6.

Paractius no'ialis Ehlers (1913), p. 500.

A very large number of specimens of this minute worm, which measures about 2-3 mm., were collected by Dr. A. L. McLean in Boat Harbour. He notes that when alive they are "pale, with dark patches dorsally." There is no pigment in the preserved worms, and it may be that he saw the black jaws through the transparent wall. 
These worms agree with the account given by Fhlers of his species, which was fomded on a single specimen. In his later memoir, however, he had a good number of individuals at his disposal, and he notes certain variations presented by them, such as the presence or absence of eyes, dctails in the form of the jaw apparatus, \&c.

The species differs from the northern $O$. puerilis Claparède and Metschnikoff, in the absence ot the ventral tentacles on the prostomium, and in the absence of the median anal cirrus, as well as in other details.

As long ago as 1888 De St. Joseph (p. 240), in describing the species Paractius mutabilis, raised the question as to whether Ophryotrocha puerilis, Staurocephalus minimus Langerhans, and S. siberti McIntosh, should not be ranged under the generic name Paractius Levinsen ; though it would have more in accordance with the usual practice to include the latter inder the earlier title. In 1895 (p. 210) he returns to the question, and records his belief that Claparède's specics is distinct from P. mutabilis.

Later, Bonnier (1893), in discussing Studer's species, notes that his account is "malheureusement insuffisant" owing to the fact that the material had been lost after the preliminary account had been drawn up. Bonnier suggests that it is probably a synonym of $O$. puerilis. He then considers the validity of Lcvinsen's genus, and concludes that it and the abovenamed species of Staurocephalus are all referable to the genus Ophryotrocha. In that work will be found a complete bibliography up to that date.

In the same year Korschelt went into the question, chiefly in reference to the jaws in the Mediterranean species, and arrived at a similar conclusion.

Ehlers (1908) makes no reference to this discussion, but does so in his later memoir, and seems to agree with the conclusions arrived at by Bonnier. Although le retains the title Paractius notialis at the head of his account of the worm, he discards it at the end ; for he writes "nach dem allen halte ich es für wahrscheinlich, dass $S$. claparedi und $P$. notialis identisch sind," and in all probability are to be assigned to the species 0 . puerilis, which would thus be a highly variable cosmopolitan species.

The only point that remains for solution is the question as to whether Studer's antarctic species is or is not identical with the northern form.

With the abundant material in my possession, I hoped to look into the question more thoroughly, but this Report has already bcen delayed by the calls on my time for University work, that this matter must for the present remain open. I hope, however, to look into it later, especially to sce whether the jaw apparatus presents any constant differences from that of $O$. puerilis.

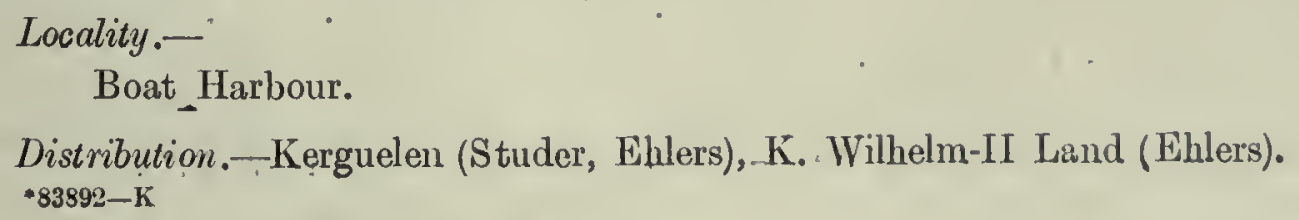




\section{Family GLYCERIDF.}

\section{Genus Glycera Savigny.}

Glycera capitata Oersted.

Oerstcd (1843), p. 44, pl. VII, figs. 87, 88, 90-94, 99.

Ehlers (1865-1868), Die Borstenwürmer, p. 648, pl. XXIII, figs. 47, 48.

McIntosh (1885), p. 343.

G. kerguelensis McIntosh (1885), p. 344, pl. XXXV ^, figs. 3-4.

G. capitata Ehlers (1897), p. 80.

G. capitata Arwidsson (1898), p. 7, pl. I, figs. 1-6, pl. IV, fig. 54 .

G. capitata Ehlers (1901), p. 154 (with synonymy).

Ehlers (1908), p. $10 \tilde{5}$.

Moore (1911), p. 299.

Izuka (1912), p. 249, pl. XXIII, figs. 11-13.

Ehlers (1913), p. 503.

Treadwell (1914), p. 198.

This species is represented in the collection by only two indviduals, both about the same size. The one more carefully studied is imperfect posteriorly, containing 62 segments, measuring. $2 \mathrm{~J} \mathrm{~mm}$. in length, with a maximum diameter of $4 \mathrm{~mm}$. some little distance behind the anterior end; it gradually decreases both forwards to $2 \mathrm{~mm}$. at the buccal segment, and backwards, so that the hinder end of the fragment is $1 \mathrm{~mm}$. It appears, therefore, that only a few segments are missing.

\section{Localities.-}

Commonwealth Bay, Station 2, 318 fathoms.

Station 12, 110 fathoms.

Distribution.-Kerguelen (McIntosh) ; Falkland Islands, Magellan Strait, Patagonian coast, Bouvet Island, K. Wilhelm-II Land (Ehlers); Azores, Portuguese coast (McIntosh); North Atlantic (Oersted); N. Pacific, Californian coast (Moore); Alaskan coast (Treadwell); Sakhalin Island, Japan (Izuka).

\section{Family SPHFRODORIDE. \\ Genus Sp hжrodorum Levinsen (nec Oersted). \\ SPH ARODORUM SPISSUM $s p$. nov.*}

(Plate 9, figs. 82-69.)

Amongst some material, containing chiefly Syllids, which Dr. Haswell found in sorting out specimens from the Macquarie Island and which he kindly forwarded to me, I find two individuals of this minute worm.

\footnotetext{
* spissus-crowded, close together; as of seats-here, has reference to the integumental papilla.
} 
One of these had been cleared and mounted in balsam-it measures $4.7 \mathrm{~mm}$., and consists of "head" and 26 chxtigcrous segments. It had apparently been fixed in osmic acid, for many of the granules in the body wall and in the interior of the body are blackencd (fig. 82).

'The other. when it reached me in alcohoi, was flattened as if it harl heen studied under a cover slip : this I stained in alnm carmine-its length is $3.5 \mathrm{~mm}$. It is rather difficult to be sure of the number of chrtal bundles, for it is flattencd asymunetrically, lying on onc side with the ventral surface upwards, one serics of parapods (of the left side) being along one edge for about half the length, the rest below the margin, the other series lying along the middle of the preparation-they are not easy to see except under a high power.

I believe, however, that there are 25 or 26 pairs of parapods. The body is not otherwise segmented ; there are no external furrows, and internally there arc several large ova which are without that regular arrangement they would have were any septa prescnt.

The ventral surface is flat, the dorsal much arched. As the animal lies the distance from one set of parapods to that on the other side is about three times the width of the ventral surface.

The whole surface of the animal is densely covered with crowded papilla (hence the specific nan:e). These are well seen in profile aloug the edge, and each is a mass of cellular substance enclosed in a continuation of the cuticle of the body. Over the body the cuticle is unusually thick, but it becomes rather thinner as it rises up to form the wall of the papilla. Within are a few nuclei stained greenish-brown (in the osmic) and some pale carmine-stained protoplasm and threads. At the base the cuticlc is pierced by a small aperture allowing a continuity between the contents and the substance of the body wall (fig. 87).

The two ends of the animal are very similar : the anterior end does not present any differentiated prostomium; no lobc is marked off from thc first body segineut. At a little distance from the end is a pair of eyes ; at least, so I interpret the structures. In the unstained clcared specimen there is a pair of sharply-defined oval vesicles surrounded by a firm membranc, pale brownish in colour, but without visible contents (fig. 83). In the stained specimen black pigment spots occupy a corresponding position.

I cannot detect any tentacles, although 1 examined both specimcns under high power. There are no processes, other than the papille, visible in these flattened specimens, and none of them are longer than their neiglibours. The anterior end, like the rest of the body, is densely covered with these papillæ.

There is no distinct peristomium; the first bundle of bristles lies about midway between the eyes and the entrance to the pliarynx, which inust be a short distance behind the mouth, whose position I am unable to determine. The structure of the head is, in fact, just as Ehlers has described it for $S$. parrum, exccpt that in that specie lhe finds distinct tentacles. 
At the hindcr end, too, I was unsuccessful in detecting anal cirri-it is inerely covered with the papillæ (fig. 84).

On the body generally, so far as it is possible to makc out in the flattened condition, the papillæ lave the following arrangement :-On the 'vcntral surface there are about five longitudinal rows of papillæ, somewhat smaller than thosc that cover the dorsal surface. Many of them arc tinged with black, as if a secretion had been affected by the osmic acid.

Between the successive parapods are two papillæ in a longitudinal row. Above them the papillæ seem to be arranged roughly in 12-15 rows, judging from the number on the exposed portion of the body - I admit there is room for error here. I have figured a short portion of the body wall at about the middlc of the animal (fig. 85). Along the dorso-lateral edge the papillæ are seen lying close together in a row ; there are no definite "small" and "large" papillæ, though they are not all quite of the same size (fig. 86). At any rate the definitc alternation, such as occurs in S. parvum (Ehlers (1913), p. 504) and S. minutum (Webster and Benedict) does not exist here.

From the edge I can trace transverse rows to the parapods, some three or four papillæ in each row ; these rows arc alternately in line with and between the parapods, and are at about cqual distance apart; those in the parapodial or mid-segmental row are perhaps a little larger than the others, but the difference is not at all well marked Also, those in any row that lie nearer to the parapods are slightly smaller than those more dorsally placed. The successive rows tend to alternate with one another in position, though this does not scem absolutely constant, while here and there amongst. the others, arc a fcw distinctly smaller papillæ.

The parapods are rather narrow, truncated cones, carrying one, or occasionally two, of the smaller papillæ on the dorsal surface near the base (fig. 86). One of the lips, the anterior I think, is produced into a rounded process, not unlike a papilla, but its contents are not cut off by cuticle from the underlying material.

I cannot see any cirri. Each parapod is supported by a single colourless aciculum, the apex of which just reaches the surface, and carries about six long colourless jointed chrtæ, the appendix of which is very thin, scarcely hooked terminally, with a thin blade in which I can detect no striations (in Canada balsam). The appendix is not unlike that figured for S. parvum, but is rather shorter (fig. 89).

In the unstained specimen the pharynx is visible, its chitinous lining being outlined by black. It is wrapped round by a coat of muscle, increasing from each end to a considcrable thickness in the middle. It occupies the second and third chætigerous scgments, i.e., its entrance is behind the first bundle, its hinder end a little in front of the fourth bundle of chætæ (fig. 83).

Around its entrance are some glands, deeply tinted black. The apparatus resembles a "pharynx," such as occurs in various families, rather than a "proventriculus" or "stomach" of the Syllidæ. 
I cannot trace any other organs.

The species is mawifestly different from S. parvum Ehlers, in which the papills are fewer, are definitely spaced segmentally in alternating rings of larger and smaller sizes. It differs from S. minutum Webster and Benedict, which is denscly clothed in papillax, but they are of two distinct sizes (larger in the parapodial levels, and two or more irrcgular rows of smaller ones betwcen); (see Southern*). Both these specics also have definite tentacles. It may be that in specimens of the new species that have not been flattened they may also be found. However, the parapods and the chrtx are dissimilar.

\section{Family ARICIID庄. \\ Genus Aricia Savigny. \\ Aricia marginata Ehlers.}

Ehlers (1897), p. 95, pl. VI, figs. 150-156.

Willey (1902), p. 275, pl. XLV, fig. 4 (spine).

Ehlers (1908), p. 116.

Ehlers (1912), p. 23.

Nainereis marginata Fauvel (1916), p. 445, pl. VIII, figs. 26-33 (juvenile form);

This spccies is characterised by the triserial arrangement of the spines in the anterior 13 or 14 neuropods ; by the absence of any fringe or papillæ in their neighbourhood ; and by the gills commencing on the sixth chætigerous segment.

The worms before me lack the black lines in the intersegmental furrows and along the margins of the gills, from which the specific name was derived, but it seems now to be recognised that these markings were due to adventitious particles.

Those from the shallower waters of Boat Harbour are white, are coiled, and have a length of about $26 \mathrm{~mm}$. Some of these contain eggs, so that they are not juveniles.

One anterior fragment from 318 fathoms is of stouter build and of a pale brown colour, with an iridescent skin. It measures $20 \mathrm{~mm}$., by $3 \mathrm{~mm}$. across the body and $2 \mathrm{~mm}$. in height. It consists of a head and only 47 segments.

The uncini have the form figured by Willey, with a spoon-shaped hollow near the end, below which are transverse ridges.

\section{Localities.-}

Boat Harbour, 2-4 fathoms.

Commonwealth Bay, Station 2, 318 fathoms.

Distribution.-South Georgia, Kerguelen, K. Wilhelm-II Land (Ehlers); Cape Adare (Willey); Roy Cove, Falkland Islands (Fauvel).

* Southern, Proc. Roy. Irish Acad. Sci. 1914, p. 90. 
A. Marginata var.nov. MC LEANi.

(Plate 8, fig. 90.)

This variety differs from the species in having in somc of the anterior neuropods an additional partial row of $3,4,5$, or 6 black spines, starting from below and cxtending upwards behind the third row. In this respect it recalls the arrangement scen in A. ohlini Ehlers (1901), which, however, possesses 10-20 of thesc spine-bearing segments in place of 13 or 14 in A. marginata.

It is truc that Ehlers (1913, p. 521), in referring to a form of Aricia from the Falklands Islands differing from $A$. marginata in having 17 such segments, exprcsses the opinion that differences in the number of anterior segments, as well as of gill-less seginents, are not of importance in differentiating species in the genus. If this is the case, it is possible that $A$. ohlini is synonymous with $A$. marginata, which agrees in most features with it, though, according to Ehlers, the position of the gill in relation to the parapod is different, for in A. ollini it is closer to the dorsal cirrus, or "lip," than in the other species; and the form of the hinder parapods apparently present certain differences, though the figures given by Gravier (1911, pl.'VI, figs. 72-73) for A. ollini are quite different from those given by Ehlers.

For the present it seems better to regard the two species as distinct, though it is clear that they are closely allied, and this new variety einphasiscs this alliance.

The additional row of spines does not exist on all the neuropods; usually they commence on the $3 \mathrm{rd}$ or 4 th, and continue to the end of the series. In some cases the third normal row is imperfect at its lower cnd, but not always, even in the same individual.

The gill commences on the 6th chætigerous segment, though in one individual it is on the 7 th, but variation in this respect is already known; and I note, for instance, that in one specimen of $A$. marginata the gill is present on the 5th on one side, and on the 6 th on the other.

Some of the spccimens are white, others are very pale brown.

'The general dimensions and other external features arc similar to those in the species.

\section{Locality.-}

Commonwealth Bay, 25 fathoms (several).

\section{Genus Scoloplos Oersted.}

Scoloplos MaWsoni sp. nov.

S. kerguelensis Gravier (ncc McIntosh) (1911), p. 108, pl. V, figs. 60-63.

$$
\text { (Plate 8, figs. 91-94.) }
$$

A vast number of individuals of this small species was collccted at Boat Harbour

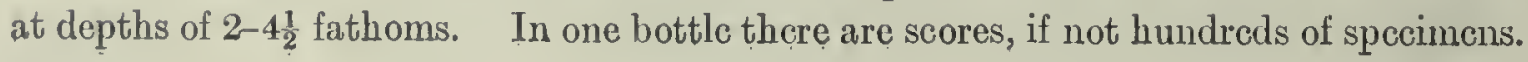


They are stated to be "red in life," but in the preserved condition, of course, this blood colour is absent; they are almost white, with the anterior end grey. The dimensions are remarkably uniform, and though most of them are curved, the length of the straight ones is $25 \mathrm{~mm}$., with a breadth of $2.5 \mathrm{~mm}$. at a short distance from the anterior end, whence the body tapers slowly backwards. The hinder end is usually imperfect, and many seem to have this region more or less regenerated.

The worm contains from 60-109 segments, the last ten or a dozen of which are very small. Many are sexually mature.

The dorsal surface is flat, the ventral very convex. The prostominm is a short truncated cone; in many cases quite blunt, in others roundly pointed. It is divided from the large peristomium by a furrow, at the anterior margin of which is a pit on each side, and immediately in front of this is a pigment spot. On the ventral surface of this region the large lateral lips are prominent, with a median lip between them.

The anterior eleven segments bear only the low parapods, with lips and bundles of chætæ. The chætæ are colourless, long, extremely fine capilliforms, with a sawlike edge on one side, which is composed of blunt, rounded teeth; the striæ between which do not reach right across the blade.

The dorsal and ventral chætæ are alike, both in the anterior seginents and in the posterior. I find no "forked" bristles, nor "acicula," such as Fauvel describes for his specimens of S. kerguelensis (1916), p. 443, pl. VIII, figs. 23-24. Each bundle of chrtre issues in front of a more or less pronounced cirrus, or "lip." The lip of the dorsal bundle is conical in form, that of the ventral is lower and of greater vertical height. In the anterior 12-14 segments the chætæe project laterally, but further back the parapods gradually rise up the sides of the body, so that the chrtæ become directed upwards. Each segment behind the 14th is triannulate, the middle annulus being much the larger of the three.

The gills commence on the 12th segment, and extend almost to the end of the worm, except apparently on the last 10 segments or so, which are very small, and have no outgrowths of any sort. The gills are sub-cylindrical, somewhat flattened on their antero-posterior faces, which increase in length towards the hinder end of the worm. till they are nearly as long as the body height.

In this gilled region the ventral surface of each segment is traversed by a glandular ridge, which commences below the parapod, where it widens out to form a triangular area with the base upwards; in the anterior segments of the branchial region, this dwindles to a small papilla and dies out.

The position of the gills is remarkably constant: thus in 31 individuals of approximately equal size, taken at random, from various vials representing different hauls, I find that in 17 of them the gills commence on the 12th segment on both sides; 
in 7 others they are present ou the 12th on one side, and on the 11 th on the other. Six of them have quite small gills on the 11th segment on both sides. One has a gill on 11th on one side, and on the 13th segment on the other.

Some of the above worms are sexually mature. But in some that are quite young, measuring only $5 \mathrm{~mm}$. I find likewise that in some individuals the gills commence on the 12th on both sides, in others on the 11th, in others again on 11th and 12tlr. In one specinen of still smaller dimensions there is a very small gill on the 10th segment.

We may, therefore, I think, regard the position of the first gill as being on the 12 th segment as a specific character.

The anus is surrounded by a thickened smooth ring, slightly notched dorsally and ventrally; I see no distinct anal cirri in any of the many specimens examined.

Localities.-:

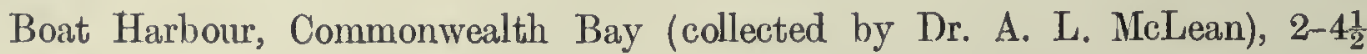
fathoms.

Distribution.-Near Port Lockroy (Gravier).

Remarks.--This worm agrees well with that described by Gravier under the name of S. kerguelensis McIntosh. At the same time he points out several features in which his worms differ from the account given by McIntosh, and he states " that it is with doubt that I identify with that species the seven small Ariciens obtained from the Roosen Channel, Port Lcckroy." The shape of the dorsal and ventral "cirri" (or lips, as I prefer to term them) differs, as also does the shape of the gills, which McIntosh figures as filiform. It may be noted that McIntosh's account and figures are not in absolute agreement as to the position of the gills. Gravier, following Ehlers, suggests that $S$. kerguelensis may be the young of $S$. armiger. His specimens, which were but seven in number, were of small size, about $17 \mathrm{~mm}$., and badly preserved, whereas mine are quite well preserved, and many are sexually mature. And since the gills commence almost constantly on the 12th segment, whereas those in S. armiger begin on the 15th-18th, and rarely as far forward as the 10th, it is evident that this surmise is incorrect, at any rate for the species studied by me, and, as I have stated, these agree quite well with those described by Gravier.

Recently, Fanvel (1916) has given a more detailed account of S. ker-. guelensis, and finds some differences from that of the previous authors. But it is clearly different from the present worm, in that the gills appear on the 18th-20th segment; he finds also certain peculiar chætæ-forked, pectinate bristles-commencing on the 10th or 9th segment; these, as I have mentioned, are not present, while on the 10th or 11th segment are one or two acicula, which are likewise absent from these worms. 
Again, the ventral "cirrus" in the postcrior feet, commencing on the 10th, undergoes reduction till it is a short obtuse "mamelon," which is not true for $S$. mavsoni, where st does not begin to become smaller till at or about the 50th segment.

It seems, then, evident that there are two species of. Scoloplos in these southern waters. That of McIntosh, Ehlers, and Fauvel on the onc hand, and the present species and that described by Gravier on the other. It remains to be seen to which of these should be ascribed those recorded by Willey (1902) under the title of McIntosh's species.

\section{Family CIRRATULID}

Genus Cirratulus Lamarck.

Cirratulus cirratus $O . F$. Muller.

Müller (1776), p. 214 (not seen.)

C. cirratus Malmgren (1867), p. 95.

Promenia jucunda Kinberg (1865), p. 254.

Promenia fulgida Ehlers (1897), p. 114, pl. VII, figs. 174-176.

Cirratulus cirratus Fauvel (1916), p. 447 (where list of synonyms and bibliography will be found).

Fauvel compared specimens from Falkland Islands, which agree in every feature with Ehlers' Promenia fulgida, with the northern form, and was unable to detect any constant differences between them. He therefore arrives at the conclusion tabulated above.

Members of the fanily are evidently rare in these southern seas, for Gravier reports on only one Cirratulus sensu lato (1911), while Ehlers (1913) gives but little information about the few that were collected by the German expedition, leaving most of the fragments unnamed.

The present collection includes a number of specimens from the Boat Harbour, and others from the Macquarie Island, some five or six in each gathering.

Although well known from the Sub-antarctic region, all round the Pole, this is the first time that it lias been recorded from the Antarctic Sea.

Iocalities.-

Boat Harbour, Commonwealth Bay, 2-4 fathons.

Macquarie, Island (low water under stones and in rock pools); collected by Mr. Hamilton.

Distribution.-South Georgia, Kerguelen, Magellan Strait, Fuegia, Falkland Islands; and also Atlantic and Arctic Oceans. 


\section{Family TEREBELLIDA.}

\section{Sub-Family Amphitritixas.}

Genus Anphitrite O. F. Müller,

Amphitrite kerguelensis McIntosh.

I. Intosh (1876), p. 321 .

Grube (1877), p. 546.

McIntosh (1885), p. 443, pl. XLVIII, fig. 7; pl. XLIX, fig. 1.

Ehlers (1897), p. 130; (1901) p. 208; (1908) p. 145: (1913) p. 556.

Gravier (1911), p. 129, pl. XII, fig. 166 (tube).

Five specimens of this large species were obtained at a depth of 157 fathoms, but none are completc. The largest measures $140 \mathrm{~mm}$. for 75 segments, with a diameter of $10 \mathrm{~mm}$. at about the 8 th segment. The tube is thick-walled, and consists apparently of fine grey mud; of which a portion measures $40 \mathrm{~mm}$. long, and has a thickness of $5 \mathrm{~mm}$. The mud contains very varied forms of diatoms, both long-shelled and circular; fragments of sponge spicules and a few radiolarian tests. It agrees with Gravier's figure, which he attributes "probably" to this species.

\section{Locality.-}

Commonwealth Bay, Station 3, 157 fathoms.

Distribution.-Kerguelen (McIntosh, Grube), Petcrmann, and S. Shetlands (Gravier), Fuegia and Bouvet Island (Ehlers).

\section{Genus Terebella (Linnaus) Malmgren.}

\section{Terebella ehlersi Gravier.}

Gravier (1906), p. 47, pl. V, figs. 45, 46.

Gravier (1911), p. 130.

Ehlers (1913), p. 556.

In the previous expeditions only one or two individuals of this Antarctic species secm to have been obtaincd, but during the visit of the "Aurora" to Commonwealth Bay, as many as fifty specimens were procured. It is then evidently fairly abundant in that area, though not nearly so common as some other species of Terebellids. In some instances the label includes a note as to colour, which is "bright red." The worm lives in depths of from 2-6 fathoms, though it seems to be commoner at about 25 fathoms, and less common at grcater depths.

There is a slight diserepancy in the account given by the two authors as to the nature of the tube. I find that the membranous basis is covered with material which varies with the naturc of the bottom; in some it consists of rather fine sand grains, interspersed with fragments of brown alga, as described by Gravier. - Other tubes 
consist of extremely fine grains of grey sand, looking like imud grains. Such tubes have thicker walls than those with coarser grains; and it is such a tube that Ehlers describes. In both kinds I find ech nid spines, and sponge spicules so embedded as to prodnce a smooth external surface.

One such tube measures $90 \mathrm{~mm}$. long, with a diameter of $15 \mathrm{nmm}$. at its upper end, and its wall is $3 \mathrm{~mm}$. in thickness.

Most of the worms measure from $50-70 \mathrm{~mm}$., with an anterior width of $7 \mathrm{~mm}$. some are larger than this, and one is $90 \mathrm{~mm}$. long. Gravier, however, gives $100 \mathrm{~mm}$. as the length of a specimen with 86 segments.

The number of notopodial bundles varies from $40,43,45$ and 49 in those examined. Gravier gives 54 and Ehlers 48.

The number of ventral gland shiclds is 14,15 and 16, in my specimens. Gravier found 14 .

There is no need to add anything to Gravier's account.

\section{Localities.-}

Boat Harbour-Among rhizoids of floating brown Algæ (Dr. McLean).

Boat Harbour, 2-4 fathoms. Station B, 25 fathoms.

Commonwealth Bay-

Station C, 15-20 fathoms.

Station D, 45-50 fathoms.

Station E, 55-60 fathoms.

Distribution.-South American Antarctic (Gravier), Kaiser Willelm II Land (Ehlers).

\section{Terebella vayssieri Gravier.}

Phyzelia vayssieri Gravier.(1911), p. 130, pl. X, figs. 121-123; pl. XI, figs 134,135 .

The tube of this species, of which several were gathered, consists of variously colonred sand grains, loosely and irregularly arranged to form a thick wall not unlike that of some tubes of $T$. ehlersi.

The worms attain a length of $40 \mathrm{nmm}$., with a diameter of $6 \mathrm{~mm}$. anteriorly, at about the 8 th segment; the body begins to contract at about the 15th segment to $4 \mathrm{~mm}$., which diameter is retained for some distance, and then it begins to taper.

There is onc point upon which I lay stress in identifying the worm, and that is the form of the uncinus in the anterior segments ; the great length of the basal process, which starts below the teeth of the uncinus, seems to be characteristic. 
There are indeed one or two points in which my specimens seem to differ from Gravier's account, which may be due to differences in the state of preservation or of age. Thus, he states that he could detect no eyes. In most of the present worms the se are distinctly present as a series of minute black dots, in two to four rows on each side: this oculiferous area occupics about half the height of the prostomium on each side. In some of my specimens, however, they are absent. And it has been noted by Ellers and other authors that in some species of Terebellids eyespots are sometimes present, sometimes absent.

I think that Gravicr must have overlooked the fact that the ventral surface of 2nd and 3rd segments coalesce, though they are distinct laterally and dorsally, and laterally the 2nd segment is very much compressed, and therefore quite short. $\mathrm{He}$ states that the "flap" is borne by the 2nd segment. I find it distinctly on the next. Also the first gill is said to be on the first segment, instead of, as I find it, on the 2nd.

Again, Gravier writes that "there is only one row of uncini." This is true for the anterior and posterior segments, but from about the 10th to the end of the thorax, that is to segment 18, I find that there are two series of uncini close together and facing alternately fore and aft, interdigitating with each other, so that they simulate a single row till examined under a microscope.

The bristles of the Ist notopod have simple points, with a narrow flange on both sides, which is not striated. But the bristles of the later segments are stouter, with a narrow flange on one side and a broader one on the other, each faintly striated.

Apart from these slight discrepancies I think there is no doubt that the worms before me are identical with those described by my French colleague.

\section{Locality.-}

Boat Harbour, $3 \frac{1}{2}-4$ fathoms.

Distribution.-Off Terre Alexandre and Port Cironcision (île Petermann).

Remarks.-Both Ehlcrs and Gravier, in discussing the allied form T. (Phyzelia) fasciata Grube, show how difficult it is to define the genera and sub-genera of this family; they give up in despair the attempt to set things right for these exotic species, although De St. Joseph has arrived at some apparently satisfactory conclusions with regard to the European species.

In dealing with this species Gravier expresses himself as being unable to decide whether it should come into the genus Polymnia Mlmgrn, or Nicolea or Scione, and yet finally he places it in Phyzelia, which has received different limitations by various authors. Under the circumstances it may be as well left in the genus Terebella lato sensu. 
Genus.Scione Malmgren.*

ScIONE Mirabius McIntosh.

Pista mirabilis McIntosh (1885), p. 454, pl. IJ, figs. 1, 2 ; pl. XXVII A, fig. 34 .

An unnamed tubc, McIntosh (1885), Introduction, p. 10, pl. XIJI, figs. 8, 9. Scione spinifera Ehlers (1908), p. 152, pl. XX, figs. 10-14.

Scione spinifera Gravier (1911), p. 134, pl. XII, fig. 156 (tube).

Scione spinifera Ehlers (1913), p. 561, pl. XLIV, fig. 7 (tube).

Scione mirabilis Ehlers (1913), p. 562.

(Platc 9, figs. 97-100.)

The material consists of seven individuals, two of which were still within their tubes, the rest having been removed thercfrom before preservation.

'The tube is nearly straight with the upper free end bent downwards as figured by previous authors. One tube measures $150 \mathrm{~mm}$. along the curve, the other attains a length of $240 \mathrm{~mm}$.; the lower end is lacking in both, but a greater portion is absent from the longer one. The tube has a cylindrical lumen, $5 \mathrm{~mm}$. in diameter; the external surface is raised into four longitudinal ridges which bear the characteristic long spine-like processes ; these are from 10-12 mm. in length in the upper region and decrease gradually towards the lower end to $1 \mathrm{~mm}$., while in the lowest quarter they are absent.

In the upper part, for a distance of about 10-20 mm., the ridges die out and the spincs depart from their regular linear arrangement, becoming scattcred over the surface. This region is of looser texture than the lower part, there being less mud adhering to the basal membrane, and consequently, too, the wall is translucent.

Embedded in the mud wall are bundles of sponge spicules, such as Mintosh describes for Pista (Scione) mirabilis ; they are disposed circularly and closely parallel to one another. They are present also in the "spines," where they are disposed lengtliwise. On the surface of the tube wall and on the spines are various colonies of Polyzoa, Hydrozoa, and a portion of what seems to be Rhabdopleura, which is unfortunately poorly preserved and the polypides are either absent or indistinct.

The complete worm removed from the smaller of the two tubes has a body length of $50 \mathrm{~mm}$. for 92 segments ; its breadth anteriorly is $4 \mathrm{~mm}$. thence tapering to the hinder end. Most of the tentacles are lacking, and the few that remain are broken.

The largest specimen in the collection had already been removed from its tube before preservation; it is about $70 \mathrm{~mm}$. in body length, to which $20 \mathrm{~mm}$. is to be added for the length of the tentacles; its diameter is $7 \mathrm{~mm}$., and the body contains about 90 segments. This specimen is twisted in the abdominal region and is somewhat soft further forwards, so that these dimensions are not absolutely correct. These spccimens are smaller than the individual of $S$. spinifera measured by Ehlers.

* Scione is anotber re ceupied name, according to Leiper. 
The anatony agrees with the account of S. spinifera given by Ehlers; but as his drawings of the animal are not very clear in certain points, I add a couple of somewhat diagrammatically constructed figures in order to show the morphological relations of the "lateral flaps," \&c. (figs. 97, 98).

In 1913 Ehlers hesitatingly suggested that possibly the two species, S. spinifera Ehlers and Scione (Pista) mirabilis MIcIntosh, are identical, for in writing of the specimcn of S. mirabilis from Kaiser Wilhelm II Land, he remarks (p. 562) :-

"Nicht völlig gehobene Zweifel bestehen darüber, ob die Würmer nicht identisch mit der von mir im vorstehenden erwähnten S. spinifera Ehl. sind."

He then goes on to discuss the few differences which are, as he tcrms them, "insignificant," and I may add comments on the four points to which he pays attention.

(1) "The differences in the structure of the tube may be due to differences in the nature of the sea-bottom, and other conditions of the habitat."

The characteristic feature of the tube both of S. spinifera and S. mirabilis is the presence of long, slender, flexible processes or " spines" which project from its surface and may be longer than the diameter of the tube.

In McIntosh's species the tube is cylindrical and the spines appear to be scattered all over the surface without any regular arrangement, but in the original account of S. spinifera Ehlers states that they are arranged in longitudinal rows. The tube figured by Gravier (pl. XII, fig. 156) as S. spinifera is likewise cylindrical with processcs irregularly disposed. But more usually in those wornis attributed to Ehlers's species they arise from definite ridges which extend almost throughout the length of the tube, and these ridges give it a very characteristic appearance, which was first figured by McIntosh (though without a name) and later by Ehlers under the title S. spinifera. He and McIntosh found three such ridges, but in the present collection each of the two tubes which I received has four ridges. I find that at about the region at which the tube curves over at its upper cnd these ridges die out and the spines lose their linear arrangement and extend irregularly over the surface. Ehlers (1913) notes, too, that the ridgei die out at the lower end in his species, though this is not the case with those beforc ine.

The material of which the tube is composed is a thin leathery membranc with fine particles of mud worked up with the secretion. These mud grains are arranged in a very regular fashion, as described and figured by McIntosh for his unnamed tube ; they are disposed in narrow circles round the circumference, each circle overlapping the next below. In S. mirabilis McIntosh observed spongc spicules embedded in the mud, closely arranged parallel to one another, around the tube ; and similar spicules contribute to the support of the processes or spines where they are arranged lengthwise. Thicse spicules were also found by Ehlers in his specimen of S. mirabilis (1913), but he did not find them in the tube of S. spinifera. 
In the two tubes, however, from Commonwealth Bay, which agree in exteruals, with the latter species, these sponge spicules are present, and their arrangement agrees. precisely with that described by McIntosh. There is thus a parallel series of form and of detail in structure in the tubes of the two "species."

Ehlers, when comparing the two "species," points out that he had no information as to whether his specimen of S. mirabilis was obtained in the same haul as his S. spinifera, i.e., whether they occurred close together, though they came from the same locality; nor had he any information as to the nature of the sea-bottom which would explain.the difference observable in the structure of the tubes.

But McIntosh found that the base of some of the tubes of S. mirabilis were embedded in sponges, which would account partly for the small proportion of mud in his tube-wall and wholly for the presence of sponge spicules.

A comparison of the sea-bottom at the localitics at which the various specimens of S. spinifera liave been obtained does not give sufficient information, I think, to account for the presence or absence of the spicules.

The "Challenger" S. mirabilis were got on a bottom of "greensand," the "Valdivia" S. spinifera from bottoms of "blue mud," of "volcanic sand" and of "mud," and Ehlers states that the tubes were covered with black and grey mud. The "Challenger" S. spinifera tubes were obtained from "blue mud."

In this recent expedition the tubes came from a bottom of "granitic rock, no ooze." No mention is made as to whether sponges were found at this station, though it is quite possible that this was the case. If so, that would account for the spicules in the wall of the tubes. Gravier does not mention whether he examined the tubes for spicules, presumably he did not, since they are not mentioned in the original account of that species.

(2) "The stem of the gill in S. mirabilis in MeIntosh's figure is longer than in S. spinifera."

But in the specimens from Commonwealth Bay which had been removed from the tube before being preserved, I find that the stem is very short, broad and wrinkled (fig. 97), and gives off two approximately equal branches ; it is almost exactly like Ehlers' figure of S. spinifera. On the other hand, in a specimen which I extracted from its tube, within which it had been preserved, the gills are bent backward ; the stem is long (fig. 98), as figured by McIntosh for his species. The difference, then, between the length of the stem of the gill, as observed by the previous authors, scems to be a matter of greater or less contraction.

In the latter individual its position, flattened against the body and fully extended, allows a careful study of its structure to be made. The stem divides into two unequal branches, one of which seems to be a continuation of the stem, the other external to it; each gives off other branches of varying lengths, which bear the terminal filaments. Figure 98 is a careful drawing of the extended gill. 
There is one point on which Ehlers makes no comment, and that is the fact that McIntosl states that the sten divides into three and that each of these splits into several branches, whereas in S. spinifera, as figured in 1908, there are only two main branches. Perlaps it is a mattcr of small importance, but it may as well be referred to here. In one of my specimens one of the two branches divides again soon after its origin, giving the impression of three divisions. MeIntosh's figure shows at least five branches, which I think is an error on the part of the artist.

(3) "Judging from McIntoslı's figure of the animal, a segment appears to be intercalated between the two segments which bear the lateral 'flaps' or lobes, and his account is difficult to correlate with the figure."

Ehlers, in describing his specimen of $S$. mirabilis, finds no such intercalated segment; the gill is on the 2nd segment, the lateral lobes on the 3rd and 4th as in S. spinifera; the shape of the first flap is similar in the two forms, and is larger than the second flap.

I have introduced a figure showing more diagrammatically than does Ehlers's figures the real arrangement of these segments. I have little doubt that McIntosh's figure is misleading.

(4) Ehlers has noted certain differences in the form of the uncinus as described and figured by MeIntosh for S. mirabilis, and those he himself describes for S. spinifera, in regard to the smaller denticles above the large fang. McIntosh describes three denticles, but his figure (pl. XXVII A, fig. 34) shows at least four and perhaps a minute fifth. Ehlers in his specimen of $S$. mirabilis finds a single tooth between the fang and the cap of small denticles, so that the uncinus appears to be three-toothed when seen from the side. In S. spinifera, according to Ehlers, this intermediate tooth is absent.

In the specimens from Commonwealth Bay, I find a difference from both these accounts, or rather from all three, for instead of there being only one intermediate tooth I find three rows of small teeth, of 2,3 and 4, or sometimes of 3,4 and 4 respectively, between the fang and the cap of minute denticles (fig. 100). In a side vicw (fig. 99) the uncinus is more like the figure of one of " the anterior hooks " given by McIntosh than to the figure illustrating Ehlers's account.

Some further points of comparison may be inade.

The dimensions of the worms have perhaps little value in deciding their identity, yet they may be included in this analysis. Ehlers's type of S. spinifera was imperfect ; but in 1913 he gives the dimensions of a complete individual.

$\begin{array}{llllrcr} & & & \begin{array}{c}\text { Body } \\ \text { length. }\end{array} & \text { Diameter. } & \begin{array}{r}\text { Number of } \\ \text { segments. }\end{array} \\ \text { Ehlers } & \ldots & \ldots & \ldots & 105 & 6 & 134 \\ \text { Gravier } & \ldots & \ldots & \ldots & 75 & - & 91 \\ \text { "Aurora } & \ldots & \ldots & \ldots & 70 & 7 & 90 \\ \text { S. mirabilis McIntosh } & \ldots & 58 & 2 & -\end{array}$


'Dimensions of tubes—S. mirabilis, MeIntosh, 150-160 $\mathrm{mm}$. by $4 \mathrm{~mm}$.;'S. spinifera, Whlers, Gravier and myself, $150-240 \mathrm{~mm}$. by $5 \mathrm{~mm}$.

Geographically and bathymetrically, the two "species" overlap. Both were obtained from Kaiser Wilhelm II Land; and S. spinifera extends up the west eoast of South America to Valparaiso (McIntosh), while S. mirabilis occurs up the east eoast as far Nortl as Rio de la Plata (McIntosh).

The depth at which the two forms have been obtained varies from 110 fathoins ("Aurora") to $2534 \cdot 7$ fathoms ("Valdivia"). These have the "spinifera" form of tube, while the $S$. mirabilis form comes from 212 fathoms (Ehlers) to 600 fatlooms (McIntosh).

It is then evident that Ehlers was fully justified in his expression of doubt as to the distinctness of the two species, and it must of course retain the name bestowed upon it by McIntosh.

\section{Locality - -}

Commonwealth Bay-

Station 2,318 fathoms (two).

" 8,120 fathoms (four, the one studied is a male).

"12,110 fathoms (a female distended with eggs).

Distribution.-Off Valparaiso, off Rio de la Plata (McIntosh), south of Bouvet Island, Kaiser Wilhelm II Land (Ehlers), Graham's Land (Gravier).

\section{Genus I.E ANA Malmgren.}

LEFNA ARENILEGA Fhlers.

Ehlers (1913), p. 564, pl. XLIV, figs. 8-13.

(Plate 9, figs. 95, 96.)

Two specimens only were obtained during this expedition, which is in contrast with the abundance of the worm off Kaiser Wilhelm II Land.

The present specimens show some apparent differences in the structure of th "head" from that described by Elllers, but whether these are due to differences of preservation, or of interpretation, or of state of development, or are specific, it is diffienlt to decide when so few individuals are available. But since the worms agree in all essential features with lis account $\mathrm{T}$ attribute them to his species, but add fignres to illnstrate the apparent discrepancies.

The tube is long and narrow, measuring $100 \mathrm{~mm}$. in length by $3 \mathrm{~mm}$. in widtlr. It is built up of a single layer of transparent, eolourless sand-grains with a slight admixture of other material, such as sponge spicules ; the outer surfaee is rough, and the grains seem very loosely adherent. It is more or less undulating, as if it had been coiled amongst other objects.

* $83892-\mathrm{M}$ 
The contained worm measures only $40 \mathrm{~mm}$., exclusive of the tentacles, which add another $10-12 \mathrm{~mm}$. to the length. It is nearly cylindrical, tapering only slightly posteriorly.

The body contains about 70 segments; the intersegmental grooves, however, are very indistinct posteriorly, so that there may be more.

The tentacular platform (fig. 95) is low, and the post-tentacular region bears an irregularly double row of eye spots laterally, but this becomes a single row across the dorsum; the right and left rows are continuous, whereas Fhlers found a short dorsal gap separating the two groups.

The first segment is very short on the dorsal surface, but becomes swollen and enlarged laterally (figs. 95, 96), projecting forward here. This glandular thickening extends almost to the mid-line on the ventral surface, but the right and left lobes become narrower as they approach one another and terminate in rounded lobes, separated by a very narrow, short, non-glandular area.

It is here that I find a difference from Ehlers' account. He represents a large oval, forwardly-directed "flap" of much greater extent, and this, instead of tapering off towards the mid-ventral line, is here almost as long as it is higher up the sides, and the two lobes overlap.

The second segment is likewise short on the dorsal surface, but is swollen so as to form a transverse ridge, which crosses the dorsum and extends down each side as far as the margin of the first gland shield. It is quite a definite structure; but in Ehlers' figure it seems to be confluent with the flap of the first segment. Possibly these structures are not at their full development in the specimens before me.

The first notopod is borne on the third segment, and the uncini commence on the fourth. On each of the segments 5,6 , and 7 there is, above the notopod, near the hinder margin of the segment, a low but distinct nephridial papilla.

There are 16-17 bundles of bristles, but there are only ten well-developed notopodial outgrowths.

The uncinigerous neuropods are short throughout the worm, and lateral in position. Anteriorly, as in the 15th segment, there are 19 uncini, but further back the number is reduced to 6 or 7 . The uncini agree precisely with the description given by Ehlers, and differ from those of $L$. abranchiata Malmgren and from $L$. wandelensis Gravier.

The ventral gland shields number 11 , and are quadrate in form, except the first four, which are narrower transverse glandular bands.

Locality.-

Commonwealth Bay, 15 fathoms (with T. ehlersi and Th. antarcticus). Distribution.-Kaiser Wilhelm II Land. 


\section{Genus TheLePus Leuckart.}

Thelepus setosus Quatrefages.

Phenacia setosa Quatrefages (1865), vol. II, p. 376.

Neottis spectabilis Verrill (1875).

Neottis antarctica McIntosh (1876), p. 321; (1879), p. 261, pl. XV, figs. 14, 15; (1885), p. 472, pl. LII, fig. 1.

Thelepus mointoshi Grube (1877), p. 544.

Thelepus spectabilis Ehlers (1897), p. 133, and his later works.

Thelepus spectabilis Gravier (1906), p. 53.

Thelepus setosus Fauvel (1916), p. 466 (for full list of synonyms).

This Terebellid, which, as will be seen, has already been described from the subantarctic under a variety of names, has now been identified by Fauvel with the European species. He had under his eyes specimens from the Falkland Islands and examples from the Straits of Dover, and arrives at the conclusion- "le Thelepus spectabilis de l'hemisphère sud ne peut être en rien differencié du Thelepus setosus de la Manche."

I can now add another locality, extending its range to Macquarie Island. Some of these, which were well preserved, were from Garden Bay, others from the North End; some were found attached to rocks below low water, others were from sand under stones at low water.

Distribution.-Strait of Dover, coast of Ireland; Kerguelen (Grube, McIntosh); Bouvet Island, Marion Island (McIntosh); Fuegia, South Chili (Ehlers); Port Charcot, Ile Booth Wandel (Gravier); Falkland Islands (Pratt, Fauvel); S.W. Australia (Fauvel (1917), p. 268).

\section{Thelepus antarcticus Kinberg.}

Kinberg (1866), p. 345.

Willey (1902), p. 278, pl. XLV, fig. 6.

Ehlers (1901), p. 210 (repeats Kinberg's record).

The brief diagnosis given by Kinberg is scarcely sufficient to enable one to visualise the species, but the few facts he does give agree with those exhibited by the specimens in this collection, and I have no doubt that they belong to that species which has hitherto been recorded, since 1866 , only by Willey.

In view of the enormous numbers that were obtained by the expedition (in one jar there are more than one hundred individuals), it is very remarkable that none of the recent expeditions to the Southern seas has met with it. 
It is very similar to the Northern Thelepus cincinnatus Fabricius, as Willey has pointed out, with which indeed he suggested that it is conspecific. But there appear to be a few differences from that Northern form, which has recently been described at length by McIntosh (1915, p. 26).

Under the circumstances, it seens worth while to give the essential facts about the worm.

The animal grows to a large size, frequently attaining a body length of $140 \mathrm{~mm}$. or even more (in one specimen it reaches $190 \mathrm{~mm}$.). To this length of body must be added that of the tentacles, which measure some $30-40 \mathrm{~mm}$., though of course they are imuch coiled and contracted, so that in life they must exceed this measurement.

The number of segments is $90-100$; the diameter of the worm first mentioned is $7 \cdot 5 \mathrm{~mm}$.

The sides of the body are thick, rough; brownish, and very glandular ; and this is continuous with the large ventral gland shields.

The cephalic collar or platform which bears the tentacles, carries numerous eye-spots over its entire extent.

There are two bunches of gill filaments on each side of segments 2 and 3 , which latter is also the first chætigerous segment. Each bunch consists of a single transverse , row of simple umbranched filaments-about 15 in a row on each side in the first gillleaving a small gap in the medi an dorsal line equal to about the width of three filaments. : The anterior gill extends downwards to below the level of the notopod. 'The second gill is smaller, and consists of some twelve filaments, and the dorsal gap is slightly wider.

In twenty-five individuals, taken at random out of a jar containing more than one hundred, every one had two pairs of gills. Not one of all those examined showed any variation in this respect, which seems to justify the use of the genus Thelepus for twogilled forms, or at any rate to refute the idea that variation in this matter commonly occurs in a species.

The first notopod occurs on the third segment and is repeated on every segment throughout the worm, though in the hinder ones the number of chrtæ becomes much fewer (in T. cincinnatus, McIntosh states that the notopod is absent in the last forty segments). 'The first neuropod lies in the 5th segment. It is of considerable extent, reaching down to the margin of the gland shield. But after the 10 th segment it begins to dwindle in height and at the same time to project outwards, so that by the 20th segment the neuropod has quite a short vertical extent not more than twice that of the notopod, and so remains throughout the greater part of the animal, as oar-like appendages.

The margin of the anterior neuroporls is darkly pigmented. The chrtx of the first notopod and of those that follow are of two kinds, as in T. setosus. 
The uncini are muiserial, small, closely-set, and numerous, there being at least sixty in one of the posterior lobes. When seen from the side the uncinus presents two teet' above the great fang, one large and one small, as McIntosh (1915, p. 29) states for $T$. cincinnatus, there is but a "single tooth," "though occasionally a mimute third tooth is visible." I find that when viewed from above the fang is crowned by a row of three teeth usually of approximately equal size, and a single minute tootl placed eccentrically outside this series ; sometimes two of these minute teeth occur.

The gland shields number 10-13, they are not at all distinctly defined, being rough and traversed by furrows. In T. cincinnatus McIntosh gives 30 shields. I looked carefully into this, and found not more than 13 in any specimen.

'The tube, as usual, is membranous, covered with sand-grains of very varied sizes ; in some cases they are so coarse as to deserve the name "pebbles," so that the outer surface is extremely rough and uneven ; in others, the grains are finer and more uniform in size and the surface much smoother. Mixed with the sand-grains are fragments of brown or green algx, and occasionally portions of Echinid tests.

\section{Localities.-}

\section{Boat Harbour, 25-30 fathoms.}

Commonwealth Bay, Station C, 15-20 fathoms (very abundant; bottom rock, with small amount of brown algx).

Distribution.-York Bay, Bucket Island, Magellan Strait (Kinberg) ; Cape Adare, S. Victoria Land (Willey).

Remarks.-According to De St. Joseph, "Thelepus" inay have one, two, or three pairs of gills. McIntosh says of "Neottis" that it differs from Thelepus in having three gills, whereas Malmgren's diagnosis defines Thelepus as having two pairs only. Willey, and I agree with him, points out the confusion that ensues from the wider use of the word; but modern writers continue to use it in this extended sense. It is evident that this large common antarctic form is common off Adelie Laind, and differs from T. setosus.

Fauvel has identified $T$. spectabilis with T. setosus Quatrefages, and in a later paper (1917, p. 269), accepting Willey's suggestion that Kinberg's species is conspecific with the Northern $T$. cincinnatus, goes even further, and, relying on the possibility that in the same species the gills may vary from two to three pairs, puts forward the view that the latter may be identical witli $T$. setosus: " Mais ceci n'est encore qu'une simple hypothèse."

The fact that in dozens of this Southern form, whether it be T. cincinnatus or not, there is no sign of any such variation shows that this " hypothèse" is still unproven, and that for the present the two species, T. setosus and T. antarcticus (or $T$. cincinnatus), are distinct. 


\section{Genus LEPREA Malmgren.}

LEPREA STREPTOCHAETA Ehlers.

Ehlers (1897), p. 130, pl. VIII, figs. 203-205.

Ehlers (1913), p. 560.

Fauvel (1916), p. 465.

A single individual of this species was received from Macquarie Island, where it lives in rock pools.

It was still invested in its sandy tube, and the animal, which is somewhat coiled, as both Ehlers and Fauvel found to be the case, measures about $45 \mathrm{~mm}$. with an anterior breadtlı of $3 \mathrm{~mm}$., tapering posteriorly.

I have nothing to add to the full accounts already published.

Distribution.-Kerguelen, Falkland Islands, Uschuaia.

\section{Genus Polycirrus Grube.}

Polycirrus hamitoni $s p$. nov.

(Plate 9, figs. 101-106.)

A number of well-preserved worms, enclosed in tubes of dark sand-grains, were found by Mr. Hamilton attached to rocks at low water on the Macquarie Island. They are described as being "pink in colour."

The worms are for the most part a good deal twisted, some are broken, but amongst them a few that are complete.

A complete specimen measures from $25-35 \mathrm{~mm}$. in length, with a breadth of $2 \mathrm{~mm}$. One mature female, filled with eggs, has a length of $25 \mathrm{~mm}$. and contains 55 segments; another of $35 \mathrm{~mm}$. has 50 segments.

The numerous tentacles are of considerable length.

There are 30-34 bristle-bearing segments, which commence on the 2 nd. The uncinigerous neuropods commence in one case on the 7 th, in another on the 11 th chrtigerous segment.

There are 13 pairs of gland shields preceded by a median shield on the first or peristomial segment (fig. 101). This gland is pentagonal in shape with its lateral angles somewhat rounded; it is crossed by a curved shallow furrow from side to side. Then follow the series of paired glands separated by a narrow but deep groove mesially. The first of these, which lies on the first chætigerous segment, is subtriangular, with its anterior side fitting against the latero-posterior border of the pentagonal gland and its apex directed mesially. The remainder are more or less quadrate. These are followed by three widely separated pairs of sinaller size. 
Below each of the first eight notopods is a small nephridial papilla, lying just outside the gland shields.

The notopods commence on the second scgment and are repcated along the greater part of the worm, i.e., for 30-34 segments; they are rather prominent, with the posterior lip produced beyond the anterior (fig. 102). The chxtæe are of two kinds-(a) those of the usual type with an symmetrical apex, a flange on one side, the sloping margin being finely striated (fig. 103); and (b) morc slender, symmetrical and without a flange, but with very fine denticulations along each edge (fig. 104). There are about ten of each kind in the anterior notopods, but posteriorly the number of each becomes fewer, and the slender form $(b)$ may be absent.

The neuropods commence below the 12th or 13th notopod; the uncini are uniserial; each has a short manubrium or base, and bears two teeth (fig. 105) with a thin curved undivided hood above them (fig. 106). Behind the teeth therc is a small projection from the base as usual, but I cannot, in spite of eareful search, detect any knob springing from the base in front of the teeth, such as Gravier figures for $P$. insignis; not even so much of a hump as McIntosh figures for Ereutho kerguelensis.

Locality.-

Macquarie Island, Garden Bay.

Remarks.-This worm does not agree with any that have bcen described from the Antarctic or Subantarctic seas. It bears some resemblance to $P$. insignis Gravier (1906, p. 54), in which, however, the first notopod is on the fourth segment and there are 11 notopods only, so that it should be placed in the genus Ereutho, if we follow Malmgren; but Gravier accepts De Șt. Joseph's views on this matter.

\section{Genus EReutho Malmgren.}

\section{Ereutho antarctica Willey.}

Willey (1902), p. 281, pl. XLII, fig. 6; pl. XLVI, fig. 6.

Polycirrus kerguelensis McIntosh (1885), p. 475, pl. XXVIII A, fig. 22.

Polycirrus kerguelensis Gravier (1911), p. 141, pl. XI, fig. 136.

nec. Ereutho kerguelensis Ehlers (1913), p. 365.

In the "Challenger" Report McIntosh describes two species of Polycirrids from Kerguelen, namely Ereutho kerguelensis (p. 474), and on the next page, Polycirrus kerguelensis: The latter was an ill-preserved fragment, and no details about its structure are given except that the uncinus is characteriscd by a very long manubrium, and bears two stout short teeth.

Willcy, in his report on the "Southern Cross" annelids gives a bricf account of a Polycirrid from S. Victoria Land which exhibits precisely similar uncini, but the 
worm has but 11 chætigcrous segments bearing notopodial chxtæ, followed by the uncinigerous segments; and therefore falls into Malngren's gcnus Ereutho. He named it Ereutho antarctica.

Consequently, if reliance be placed wholly on the form of the uncinus, wiich certainly is quite peculiar, MeIntosh's Polycirrus kerguelensis is in all probability this Ereutho; but he had already given the spccific name "kcrguelensis" to an Ereutho which has quite a different form of uncinus. Hence a new specific name is needed, and we must adopt Willey's name " antarctica."

Gravier (1911) describes, under the title "Polycirrus kerguelensis McInt.," a worm which has 11 chetigerous and 25 uncinigerous segments, whose uncini agree precisely with the figures of McIntosh and Willey, and he remarks (p. 143) that it is eztremely probable that it is identical with Willey's spacies.

Later, Ehlers (1913), under the title "Ereutho kerguelensis McIntosh" (which he regards as synonymous with Willey's $E$. antarctica), describes a worm with uncini agreeing with that figured for Ereutho kerguelensis (not Polycirris kerguelensis) of McIntosh, but differing from that figured by Willey for his species.

Ehlers states that the only difference between the two is that McIntosh records 13 chætigerous segments, while Willey gives the number as 11 . Ehlers himself finds both 11 and 12 ; and as the number of notopodial scgments is variable, he concludes that the two species are identical. But this leaves aside altogether the marked difference between the uncini in the two cases.

'. Ehlers refers to the conspicuous anterior lip of the anterior notopods produced into a "papilliform process" (McIntosh), but neither anthor figures it. I do not see any such striking feature in the present worms; the lips are nearly of a size.

The present collection contains specimens of this species, without their tubes. The worms arc for the most part coiled, and measure about $12-15 \mathrm{~mm}$. with a diameter of $3 \mathrm{~mm}$. anteriorly.

There are 11 segments bearing notopods with capillary chæcte, followed by 25-30 segments carrying short projecting uncinigerous neuropods. The first notopod is on the third segment above the first pair of ventral gland shields.

A mounted piece of the thoracic pre-uncinigerous region shows none of the peculiar hooks below the capilliform chætæ such as Ehlers describes in his Ereutho kerguelensis.

The present worms agree generally with the account given by Gravicr.

\section{Iocality.-}

Boat Harbour, $3 \frac{1}{2}$ fathoms.

Distribution.-Kerguelen (McIntoslı), South Victoria Land (Willey) Petermann, and South Shetlands (Gravier). 


\section{Family AMPHARETIDA.}

\section{Genus Phy locomus Grube.*}

\section{Phylloconus mibranchiata $s p$. nov.}

(Plate 10, figs. 107-123.)

A worm which was dredged from a depth of 157 fathoms, seems to form the type of a new species of this rare genns.

It is distinctly differentiated into thorax and abdomen, the former bearing both notopodial chrte and rncinigerous neusopods, the latter presenting only the neurcpods, whi h project laterally like wings o: oars.

The specimen (fig. 107) is very well preserved, and appears to be strongly contracted anteriorly ; it is a pale yellowish colour, while the parapods and glands are pale brownish and the ventral surface of the abdomen rather darker.

It is fortunately complete, though the hinder end appears to be regenerated, as no uncini can be detected on the last ten segments.

Its total length is $45 \mathrm{~mm}$., with a width of $11 \mathrm{~mm}$. anteriorly and a height of $8 \mathrm{~mm}$. The body tapers backwards slowly, so that at the commencement of the abdomen it measures $6 \mathrm{~mm}$. in width.

The worm contains 60 segments, with head and anal fumnel, which is surrounded by a number of short cirri (fig. 115). There are 15 notopods with long pale yellow chætæ; 14 of these thoracic segments are glandular across the whole ventral surface, though distinct gland shields are not evident. The anterior glands spread from the nenropods of one side to those of the other, which are here separated by a space of $8 \mathrm{~mm}$. The last three or four are traversed by a definite furrow in the middle line. There are indications of two additional glands behind these.

The head (figs. 108, 109) is very obliquely tnnncated, so that its anterior face is nearly vertical; the prostominm has the form of a sub-circular plate sloping downwards from the dorsal surface of the body, nearly at right angles to the body axis; the lower extremity of this plate is free, and its edge is thin. This prostomial plate is of firm consistency, almost chitinoid; it is tinted in the middle with reddish brown pigment, is slightly convex from side to side in its middle, and slightly concave from its front backwards, so that its free rounded edge projects horizontally.

On each side, between the prostomial plate and the curved peristomial ridge, is a narrow elongated depression from which a slight papilliform elevation rises. Grube suggests that this is a secretory organ; perhaps, however, it represents the ciliated

" "Phyllocomus" luoks likc a masculine word and appears to refer to the "foliaceous" form of the gill ; but Grube uses the feminine "crocea" for the species. I therefore consulted my Classical colleague, Professor Adams, who informs me that there is a rare Grcek word "komos "mcaning a "bundle or sheaf," which is feminine : presumably" Grube used this rare word.

*83892-N 
nuchal organ of many Polychaeta. Just anterior to this, but only visible from the ventral surface, is a little patch of pigment a short distance from the antcrior margin of the prostomial plate; this probably represents an cye-spot (fig. 113).

The prostomial plate is continuous dorsally and laterally with a curved semicirenlar ridge, from which it is separated by a shallow furrow, but this ridge is also continued downwards across the ventral surface to form the lower lip, which is closcly pressed against the upper lip formed by the prostomial plate, the anterior edge of which it does not reach (fig. 103).

Whether one is to regard this curved ridge as the hinder region of the prostomium, such as is described for several Ampharetids, or as the peristomium, seems uncertain; but from its relations I takc the latter view.

The ventral region of this peristomium is produced forwards in the middle line, so that a median and two lateral regions of the lower lip are distinctly marked off from one another (fig. 113); the median lobe has a straight transverse edge which is abruptly limited on each side by a nearly longitudinal margin, that turns sharply outwards to form the anterior edge of the lateral region of the lip. When the animal is seen from above, this lower lip is invisible, since it is overhung by the prostomial plate, and even when viewed from below, its base is partly concealed by the forward extension of the ventral surface of the following segment.

The branchiferous segment, the second of the body, is very much compressed on its dorsal portion, so as to form an upstanding fold; its ventral portion is thick and glandular and conceals in great part the lower lip.

On the dorsal surface this segment is rather longer than the peristomium, and carries a pair of admedian, upstanding gills of cnusual form and structure (fig. 109). Each gill is $4 \mathrm{~mm}$. in height, i.e., about lialf the hcight of the body at this point; it consists of a rather thick axis, which bears along its whole length four undulating tough membranes, two on the external and two along its interual or medial surface. The membranes are broad below and taper distally so that the form of each gill may be described as quadrifoliaceous and lanceolate, in Grube's terms.

The two gills are connected at their bases by a low transverse membraneous ridge (perhaps exaggerated by the contraction of the body), which is continucd outwards and downwards almost to the level of the notopods of the following segments.

Passing backwards and outwards from this ridge, commencing behind each gill, is a deep channel, bounded by a couple of narrow walls which, about midway in their course towards the base of the third notopod, unite above the channel and convert it into a tunnel. This tunnel appears to end blindly (fig. 110).

Two quite similar but successively shorter structures pass from the branchiferous ridge towards the second and first notopod, above which they respectively terminate. 
These structures appear to be the "areolx" of Grube's account of Phyllocomus crocea (1877, p. 543), and the relative disposition of them seculs to correspond to the three structures figured by McIntosh (1885), pl. XLVII, fig. 11), which he interprets as the bases of lost "gills."

These three pairs of channcls and tumnels appear to be nnique, and I regret that, having only a single specimen of the worm, I am unable to examiule them by scctions. I have no suggestion to make as to their purpose. The worm is well preserved, and there is no evidence of rupture here, no suggestion that any structure, such as a gill, has been broken away; the margins of the channels are rounded and smooth, and appear quite natural. At any rate, under the highest power of a dissccting microscope I can see no sign of any interruption in the continuity of the surface.

The tentacles, as is usually the case in the family, are invaginated into the buccal cavity. They were exposed by slitting up the side of the body along a line corresponding to the junction of the lower lip with the peristomium (fig. 113). Tten numerous filamentous tentacles are seen directcd backwards along the roof of a cavity, which I suppose is the buccal cavity; they are borne by a rounded ridge, which extends across the base of the prostomium, curving forwards on each side till ncarly in the line of the lateral margin of the lower lip (fig. 116).

Within the lower lip, along its base, is a second rounded ridge which connects right and left with the tentacular ridge; it is apparently a sphincter muscle, and may be exaggerated by the contracted state of the worm.

The tentacles are $10 \mathrm{~mm}$. in length and are united to one another for a distance of about $3 \mathrm{~mm}$. from their origin, where they are only indicated by lines separated by shallow furrows. The proximal portion of the tentacles is surrounded by a thin membranous flap, $1 \mathrm{~mm}$. in height, springing from the tentacular ridge; and when the tentacles are lifted up a line of brown-red pigment-dots is seen close to its free margin on its tentacular surface; further, a second line of darker spots lies along its base, close to the roots of the tentacles (fig. 117).

The body.-The dorsal surface is smooth, annulate and without jnter-segmental furrows, but the segments are distinct enough laterally and ventrally; the body is very strongly arched, so that the notopods are directed upwards ; the third segment, like the rext two, is much narrower than the following, though whether this is again due to the strong contraction of the worm seems doubtful, in light of the statement by Grube that in his species these three segments are shorter than the rest.

The third segment carrics the first notopod, which is smaller than the following, and bears only a few chætx. The next two notopods are likewise small, but the number of chrtx increases; the maximum is attained at about the sixth or seventh, and this is retained until the fourteenth.

The bristles are long, stout and of a golden-yellow colour ; they are arranged in a single vertical series with longer ones above and successively smaller ones below. 
Microscopical study of them, under varying conditions and from different aspects, reveals a new type of bristle; new not only to this family but, as I think, new to the class.

Some time previously I had made a drawing of one of the chaetæ from a group separated out and freshly mounted in glycerine; it was symmetrical, finely pointed with a narrow flange on each side, and very similar to that figured by Fauvel (1897) for Ampharete grubei (pl. XVII, fig. 24.) But amongst them I found others in which the bristle is curved and has only one rather broader flange. I supposed therefore that there were two kinds of chaetre in the bundle.

Some months later, when preparing this account for publication, I had occasion to refer to my preparations, one of which was in Canada Balsam. I was surprised to see that all the chætæe are alike, curved, with a single flange. Wishing to ascertain how I could have been deceived in my earlier examination, I cut off a fresh parapod, separated out the chre tre and made a new mount in glycerine.

Again I saw in most of the chætæ two narrow flanges. I then pressed the coverslip so that the chrte might be flattened out a little; now all of them had a single flange. I then lifted the coverslip, turned the chrte about and re-examined them. Again I saw several with the two flanges.

A careful study under a high power informed me that the chæta really has three flanges, two narrow ones lying in one plane, symmetrically arranged, and a third broader one in a plane at right angles to them; and in this position the chreta is curved. Having made this discovery, it was easy to detect the three flanges in some of the chætæ, and I have drawn one of them (fig: 118-120).

To what extent this observation may shed light on discrepancies in the accounts of chætæ in some families, e.g.., the Terebellidæ, I cannot say. It is evident that a renewed study of the bristles in certain families is desirable.

The ventral surface of the thorax is nearly flat, and traversed by a wide shallow median furrow, which increases in depth posteriorly, and after the last gland shield becomes very deep but narrower; the margin of the furrow is formed by the rounded muscular ridge on each side.

The uncinigerous neuropods commence below the 4th notopod. Those on the anterior segments of the thorax are vertical ridges, limited to the sides of the body, and originating near the hinder boundary of the segments; their edges rise only slightly above the surface. In the hinder segments each neuropod becomes more prominent, thick and fleshy, while in the abdomen they are narrower and become flap-like (fig. 114). The neuropod is now a quadrangular flap directed backwards and outwards; its free edge carries the uncini. On its upper surface near the body wall is a small rounded papilliform upgrowtl (which is, perhaps, a dorsal cirrus). By the 12th abdominal the neuropods are already much longer and project still further; the dorsal 
"cirrus" has increased in size, and has become sub-cylindrical; the distal upper angle of the foot becomes produced into a distal cirriform process (? the "lip)" of the chætophore), in addition to the dorsal " cirrus" (fig. 121).

The neuropods decrease in size posteriorly, and the inferior angle becolnes more marked.

The general form of the neuropod is similar to that occurring in other Ampharetids, but the presence of both the proximal "papilla" and the distal "supra-uncinal process" seems unusual. The proximal papilla, which I have termed "cirrus," is usually regarded as equivalent to a vestigial notopod; and the distal process to the dorsal cirrus (cf. Fauvel (1897), Ehlers (1887) p. 220).

The uncinus has five teeth in a single series, and a small prominence between the smallest of these and the rounded upcurved extremity of the plate (figs. 122, 123); it is quite similar to that figured for P. crocea by McIntosh (1885), pl. xxvi a, fig. 25).

The structure of the gill (fgs. 111, 112). Although the condition of preservation is not sufficiently good to allow a thorough study of the gill to be made, the examination of a short series of transverse sections enables me to give an account of its more striking features.

The gill axis is traversed by a canal, whose wall is composed chicfly of unuscle. Externally there is a layer of tall columnar cells bearing a thick cuticle; within this is a thin circular coat of muscle, which envelopes a thicker coat of longitudinally arranged muscle fibres. This does not seem to be limited very definitely internally, for there is a layer of loose.connective tissue, in which are scattered irregularly a number of small round nuclei. At places in the series of sections I believe that I can detect the remains of a thin membrane forming the lining of the axial cavity; but the tissue is here broken and imperfectly preserved, and it may even be that the canal is an artifact, and that the axis is occupied by a core of loose connective tissue.

Running along the wall of the axis at two opposite points is a blood vessel, lying apparently in the longitudinal muscle coat, but in places it projects into the cavity.

The folia or gill membranes are, of course, cut transversely; the central part consists of connective tissue, enveloped in the epidermis. I can see no cilia, thouglı perhaps this is due to the state of preservation. A series of blood vessels is cut across, lying close to one another along each side, underneath the epidermis. They give to the section a very characteristic appearance, and seem to be connected across the folium; but I was unable to trace out precisely how or where they communicate with the axial blood vessels.

\section{Locality.-}

Commonwealth Bay, Station 3, 157 fathoms.

Remarks.-That the genus Phyllocomus is rare is evident from the fact that although it was established by Grube as long ago as 1877 for the species 
P. crocea, it has only been reeorded sinee that date in the "Challenger" report. Grube's material appears to have been but a single specimen, which was oltained between Heard Island and the Crozets. That eollected by the "Challenger" eame from Kerguelen.

I regard the present as a different speeies sinee Grube deseribes two pairs of gills in some detail, and he makes no mention of the four membranes springing from the axis; he deseribes the gill as foliaceous " quasi lanceolata." McIntosh gives a brief aecount of a mutilated anterior end of a worm which he ascribes to Grube's speeies. His figure (pl. XLVII, fig. 11), agrees in general form quite elosely with the worm herein deseribed, but is withont any gills. In the text he writes (p. 427), "the next segment bears dorsally the marks of four branehial proeesses on each side."

His figure shows three pairs of pit-like structures, which are no doubt the "ehannels" that I describe above, and which I suppose Grube refers to as "areolæ." McIntosh seems, however, to interpret them as the base; of gills. They have the same relation to one another and the same position on the segments as I have described. It may be very likely that he had before him the present speeies.

As both these accounts are brief, and as only one figure of this interesting genus has been published, it has seemed to me worth while to give rather a detailed deseription of the worm.

\section{Genus Aмчтнаs, gen. nov.*}

\section{Amythas membranifera, $s p$.nov.}

(Plate 10, figs. 124-132.)

A single individual of this remarkable worm was obtained from a depth of 325 fathoms in Commonwealth Bay.

It is imperfeet posteriorly, laeking, however, only a few segments, and consists of a head and thirty segments, measuring $60 \mathrm{~mm}$. in length, with an anterior diameter of $12 \mathrm{~mm}$., which diameter decreases posteriorly till at the end of the fragment it, is only $5 \mathrm{~mm}$. The anterior region is a good deal contracted, and the animal was ruptured about half-way along its length, and broke into two piees on being handled.

As in other genera, the body is divisible into two regions, thoracic and abdominal ; the former is indicated by the seventeen pairs of notopods with capilliform chretæ, which are absent in the abdomen. The thoracie region appears to be strongly contracted, so that probably the dimensions of the worm just given are not quite correet. The whole

* The name is formed by transferring the initial " $\mathrm{S}$ " of Samylha to the end. 
dorsal surface is very convex, and the segmentation is obscured by numerous closcly set annulations. The ventral surface of the thorax is highly glandular, but no definite "gland shields" are delimited, as the glandular modification of the integument extends across the ventral surface from right to left unicinigerous nueropods; but on the last three segments the outlines of the glands are cvident.

In the abdomen the ventral surface is deeply concave, crossed, however, by segmental rounded, transverse ridges.

The prostomium (figs. 124, 125) consists of two portions, viz-(a) an anterior freely projecting flap overhanging the mouth; and $(b)$ a posterior thickened transverse fold, which is almost entirely hidden by the basal portion of the second or branchiferous segment.

The prostomial flap, or upper lip, is slightly trilobed, the middle lobe being more prominent than the later regions, from which it is marked off by a slight notch on each side. The middle lobe is inclined forwards and upwards, and has a somewhat thickened free edge. On raising the prostomial flap, or on looking into the mouth from in front (fig. 127), the base of the prostomium is seen to be continuous, with a transverse lobulated structure, or "supra-oral arch," which is separated from it by a furrow. The right and left extremities of this arch touch the upper part of the lowcr lip on either side; the median portion of it is smooth, and traversed by a number of fine furrows radiating from its base forwards towards its edge; the lateral portions are thick and swollen.

The buccal segment or peristomium is represented dorsally by a rounded transverse ridge, overlapped and concealed by the branchiferous segment. Ventrally, however, it is produced forwards to form a great lower lip, which is scparated from the lateral region of the prostomial flap by a deep, horizontal cleft on each side, and it is evidently very mobile (fig. 126).

Between the upper and lowcr lips there projects a folded membrane (fig. 127), which occupies the entire oral cavity. At first I supposed this to be a part of the gut everted, but found on dissection that it has the following relations, from which it is clear that it represents the series of tentacles of other Ampharetids. The free edge of this " tentacular membrane" is tlickened in the median region, but becomes thimer towards each side. It is folded much in the way that a partially closed fan is folded, but the folds are few and irregular. It arises from the under surface and postcrior margin of the "supra-oral arch" above mentioned (fig. 123), which is thus seen to correspond to the tentacle-bearing ridge of other genera. The line of origin of the tentacles is at about the level of the junction of the arch with the prostomial flap. At this point-as was seen by slitting open the body wall-the buccal cavity (or œesophagus ?) commences ; this is a tube with a thick, muscular wall, whose inner surface is thrown into a number of rugæ. Its floor is produced forwards to form an internal lip, suclı as that figured by Fauvel (1897) for Ampharete yrubei. 
This tentacular membrane, then, has the same topographical relations as the bundle of filamentous tentacles in other genera of the family, and it is unfortunate that, having only this single individual, I am unable to study its structure as fully as it deserves.

Following the peristomium is the branchiferous segment (fig;. 12 ', 125, 126). Its dorsal surface is raised up as a transverse fold, which overhangs the peristomium and the posterior portion of the prostomium. It is continued downwards as an ordinary segment, but is without chætæ. This segment carries threc pairs of gills, which arise in a transverse line; they are long, simple, sub-cylindrical, and grooved along the posterior margin. The base is more or less expanded, and each terminates on a bluntly rounded extremity. Of the six gills, however, only two remain entire : on the right side the most dorsal, which is $15 \mathrm{~mm}$. long, and on the left side the middle gill, which is $10 \mathrm{~mm}$. long; the other four are represented by more or less of their basal region.

The two most dorsal gills are close together near the middle line; the base of each is produced outwards as a rounded ridge, passing obliquely outwards across the dorsum to end at the base of the second notopod. The second gill is immediatcly external to the first, and the third lies just above and in front of the first notopod.

There are seventeen pairs of notopods, rather prominent lobes, carrying very long, stout, brown bristles; the first notopod is on the third segment, which is much compressed between its neighbours (this is perhaps due in part to the contraction of the body); it is smaller than the rest, and carries fewer and shorter bristles; the secrnd is longer, the following increase in size, and the full development of the foot is attained at the sixth or seventh.

The bristles, of which there is a considerable number in each notopod, arranged in a double or triple vertical series, are brownish in colour ; each is long, thick at the base, slightly curved, and produced into a very fine point; there is single flange on the convex border.*

The uncinigerous neuropods commence bclow the fourth notopod on the sixth body scgment ; they are definite, wing-like, mobile organs, increasing in prominence posteriorly. In the thorax the neuropod has a long, vertical, uncinigerous margin, equalling in height that of the organ itself, but in the abdomen the neuropod is very convex superiorly, and has a short uncinigerous margin directed somewhat downwards (fig. 129).

The uncini are uniserial throughout the body, and number about eighty in the anterior feet.

The uncinus (figs. 130, 131) has two rows of four nearly equal teeth, springing from a short, broad base, which is produced into a rounded lobe beyond the fourth

*Treated as I treated the cheta of Phyllocomus I find that the two literal flanges are not present. 
tooth, whieh is slightly smaller than the others; the base has also a small lobe on its lower edge below the first tooth. 'The meini are similar throughout, but on the thorax are larger than on the abdomen.

\section{Locality.-}

Commonwealth Bay, Station 10, 325 fathoms.

Remarks.-The worm agrees fairly well with Malmgren's diagnosis of Samytha, from which it differs in three noticeable features-(1) the form of the prostomium; (2) the presenee of a folded membrane in plaee of filamentous tentaeles : and (3) the form of the uneinus. It bears no resemblanee to the only known Antaretic Ampharetid Samytha (?) speculatrix Ehlers (1913, p. 554). Consequently, a new genus is neeessary, which may be defined as follows :- "Ampharetids with a trilobed prostominal flap; tentaeles represented by an invaginable membrane; three pairs of eylindrieal gills on the seeond segment; seventeen pairs of notopods; uneinus with four paired sub-equal teeth on a broad base.

\section{Family CAPITELLID长.}

Genus Isomastus Gravier.

\section{IsOMAsíus PERARMATUS Gravier.}

Gravier (1911), p. 113, pl. VIII, figs. 88-93; pl. IX, figs. 94-108.

Four speeimens of this, the only Capitellid known from the antaretie, were gathered, amongst which a well preserved male measures $42 \mathrm{~mm}$. in length by $2 \mathrm{~mm}$. in diameter anteriorly; it contains fifty-two segments following the head. There is also a female in the collection.

\section{Locality.-}

Boat Harbour, Commonwealth Bay, $3 \frac{1}{2}$ fathoms.(muddy bottom).

Distribution.-Adniralty Bay, South Shetlands, Petermann (Gravier).

\section{Family MALDANTD Æi.}

\section{Genus RHodine Malmgren.}

Rhodine intermedia Arwidsson.

Ardwidsson (1911), p. 11, pl. I, figs. 5-11; pl. II, figs. 39-41.

R. loveni Willey (1902), p. 276, pl. XLVI, figs. 3-5.

R. antarctica Gravier (1906), p. 39, pl. IV, figs. 33-37.

R. loveni Gravier (1911), p. 125, pl. IX, figs. 110-112; pl. X, fig. 114; pl. XI, fig. 133.

A single imperfeet specimen, coissisting: of the head, followed by thirteen ehætigerous segments, and another portion consisting of six posterior segments, measure in all $35 \mathrm{~mm}$. by $1 \mathrm{~mm}$. in diameter. 
Previous authors have noted the readiness with which the hinder segments break away, owing to the extremely slender connections between them, so that the true dimensions of the species is unknown.

It is alınost colourless, except that in front of the chætæ of each of the segments 4-10 is a pinkish area occupying more than half the length of the segment. This is the "anterior glandular band" of Arwidsson, with which the indistinct "posterior band" is continuous. There is no need for me to add anything to Arwidsson's exhaustive study of the species.

Locality.-

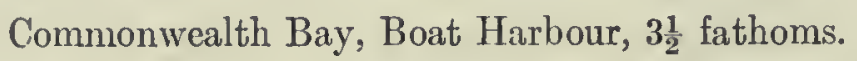

Distribution.--Cape Adare, Victoria Land (Willey); Port Charcot and Petermann (Gravier); South Georgia (Arwidsson).

Remarks.--It is thus circumpolar.

\section{Genus isocirrus Arwidsson.}

\section{IsOCIRRUS YUNGI Gravier.}

Gravier (1911), p. 122, pl. IX., fig. 109; pl. X, figs. 115-120.

Gravier's type specimens were two fragments, of which one was an anterior portion and the other a short piece of the hinder end. They are a good deal smaller than the specimens collected by the "Aurora," and the tube in which the animal lived was not collected or reported upon.

Eleven individuals of the species, mostly imperfect, were obtained at a depth of 157 fathoms. In most of them the body is encircled by a portion of the nud-tube, which has a very thick wall; thus a worm measuring $7 \mathrm{~mm}$. in diameter fills the lumen of a tube whose external diameter is $11 \mathrm{~mm}$., so that its thickness is $2 \mathrm{~mm}$.

A complete individual studied is $110 \mathrm{~mm}$. in length with a breadth of $5 \mathrm{~mm}$. anteriorly. Another one, lacking only the anal funnel and a portion of the long preanal segment, attains a length of $135 \mathrm{~mm}$. with a breadth of $7 \mathrm{~mm}$.; but judging from some of the fragments still within their tubes, the species may reach even a greater size than this.

The colour is almost uniform pale brown, except that in one or two cases the 5 th and 6 th segments are darker than the rest; the glandular band at the commencement of the segments is nearly white.

The complete individual first mentioned above consists of the " head," followed by nineteen elongated chætigerous segments and a long preanal segment; this bears six glandular half-rings, corresponding in position to the uncinal glands to be described 
below, and so probably represents six segments; of these glands the three anterior extend further round the body than do the other three. 'I'he body terminates as usual in an anal funnel.

The uncini commence on the 5th segment, and the neuropods of the last seven segments are very prominent.

In the 2nd, 3rd, and 4th segments there are one or two short, stout, bluntlypointed spines below the small bundle of capilliform chætæ: Gravier in speaking of these says that there is "une rang e de crochets ventraux"; if by this he means a vertical row of hooks the statement does not apply to these spccimens.

The " head," i.e., the prostomium and peristomium, is equal in length to the 2 nd segment; each of the next five segments is approximately equal to this; but each of the following six is a good deal longer. But it depends on the state of preservation, for in some extended worms this difference between the first five and the next six is hardly noticeable. The chætæ in this genus are inserted near the anterior boundary of the segment; in the first five, at about one-third; in the following six or more, at about one-fourth the length of the segment.

There is a glandular band surrounding the prechætal region of each segment, this is interrupted on each side by a deep, narrow, horizontal furrow. This glandular band forms, in some individuals, a feeble collar, but in extended specimens the overlap is not apparent. At the segment on which the true hooks appear, namely, the 5th, there is also a post-chætal gland; at first this is narrow, but as the serics of uncini becomes longer this gland increases in width as well as in length. By the 8th segment the prechætal band is differentiated into a narrow dorsal and a wider ventral portion; and the ventral gland, which now appears as a large oval patch, overlaps the previous segment more distinctly. By the 10th the dorsal gland has become considerably reduced, and on the 11th has disappeared, so that posteriorly only the ventral or uncinal gland persists; this enlarges in the segment further back, till in the 17tll, for instance, it covers half its length.

I have given these details as Gravier says nothing about them; the arrangement is entirely in agreement with the general character of the glands described by Arwidsson for the genus.

Gravier's account of the prostomium, or cephalic plate, needs no addition, thougl his figure is somewhat diagrammatic. The dorsal transverse portion of the membrane that surrounds the plate is crenated. He states that there is a dozen low rounded lobes, but I find that the number and form is variable. Sometimes they are uniform in size, though in some individuals they may be larger than in others; in the former case I counted 18 lobes, in the latter as many as 25 . In other individuals, the smaller and larger lobes are irregularly alternating.

The anal funnel, as the generic name implies, is surrounded by uniform digitations, of which I count as many as 36 . 
A figure of the capilliform ehatæ is given by Gravier; but his interpretation of the hook is not quite in agreement with what I see. . The large fang is sumounted by four others of much smaller size; and there are some laterally situated small teeth at the base of the large fang. Further, the bay between the fang and the bundle of threads is deeper and roughly semicireular in outline.

It may be that these small differenees depend on the segment or region of the worm from which the uneinus is taken.

Locality.-

Station 3, 157 fathoms.

Distribution.-Petermann.

\section{Family ARENICOLIDE.}

Genus Arenicola Cuvier.

Arenicola ASSimilis, var. AFFinis Astworth.

Ashworth (1903), p. 760, pls. XXXVI, XXXVII.

Ashworth (1912), p. 123, pl. VII, fig. 16 ; pl. X, fig. 29 ; pl. XIII, fig. 45; pl. XIV, fig. 50 (a full bibliography herein).

Fauvel (1916), p. 455.

'T'wenty speeimens, earefully preserved in formaline, were eollected by Mr. Hamilton at Maequarie Island, where they are common, embedded in sand and broken shells, between roeks, two inehes below the surfaee at low tide.

; They vary in length from $40-140 \mathrm{~mm}$. The eolour in life is stated to be for most of them "pale green with red gills." . These have turned brown in the preservative; others were " dark green" in life, and have beoome almost black.

\section{Locality.-}

Garden Bay, Maequarie Island.

Distribution.-New Zealand, Magellan Strait (Ehlers); Falkland Islands (Ashworth, Fauvel); North Tasmania, Table Bay, S. Afriea (Ashworth); Campbell Islands (Benham).

\section{Family CHLORHALIID}

Genus Flabelligera Sars.

Flabelligera mundata Gravier.

Gravier (1906), p. 37, pl. IV, figs. 31, 32.

Gravier (1911), p. 110, pl. VIII, fig. 87.

Ehlers (1912), p. 25.

Ehlers (1913), p. 535, pl. XLI, figs. 1-12.

Of the three specimens in the colleetion, the largest measures $93 \mathrm{~mm}$. in lengtli; ts greatest breadth is $18 \mathrm{~mm}$., its height $10 \mathrm{~mm}$. It is thus larger than that deseribed by Ehlers. 
The 26 bundles of eapilliform ehatre project for 16-25 $\mathrm{mm}$. beyond the translucent, firm, jelly-like investment of the body, which is here greyish, not yellowish-brown as described by the previous authors. 'The chrtre, whieh are eovered with mud, are aecompanied by long-stalked clavate papillæ.

\section{Localities.-}

Station 10, 325 fathoms (one).

- Station 12, 110 fathoms (two)

Distribution.-Port Chareot, Soutl Shetlands (Gravier); Kaiser Wilhelm II Land, South Victoria Land (Ehlers).

Family SABELLIDA.

\section{Potamilla Malmgren.}

\section{Potamilla antarctica Kinberg.}

Laonome antarctica Kinberg (1866), p. 354.

Laonome antarctica Ehlers (1897), p. 135 ; (1901), p. 216.

Potamilla antarctica Gravier (1906), p. 59, text-figs. 38-43.

Potamilla antarctica Gravier (1911), p. 144, pl. XI, figs. 137-141.

Potamilla antarctica Ehlers (1913), p. 575.

Potamilla antarctica. Fauvel (1916), p. 474, pl. VIII, figs. 4-7.

Of this species, so widely and abundantly distributed through the antarctic seas, a large number were forwarded to me. They may be grouped for convenience of referenee into two lots; partly from their geographical range, and partly from the size of the individuals.

Group $A$ consists of small individuals from $25-40 \mathrm{~mm}$. in length, exclusive of the gills. These occur on the shores of Macquarie Island. 'They agree in dimcnsions, as well as in external features, with the worms deseribed by Ehlers, Gravier,* and Fauvel, whieh has hitherto been regarded as the typieal eondition of the speeies.

Group $B$ contains much larger worms, attaining lengths ranging from $72 \mathrm{~mm}$. up to $230 \mathrm{~mm}$., exclusive of the gills. These come from Commonwealth Bay, at various depths; and the larger ones exceed in size the largest specimen, of which the dimensions have hitherto been recorded, namely, that mentioned by Ehlcrs as being $170 \mathrm{~mm}$. in length, obtained from South Victoria Land.

From their much greater dimensions I expected that these would prove to belong to a different spccies, but after examining them from every anatomical point of view, I came to the conclusion that there are no features that distinguish them from the more typical specimens under Group A', other than their sizc.

* Gravier describes the species as if it were new, affixing his own name after it. 
We must therefore regard them as older, perhaps much older, stages of development than the smaller ones.

I will deal with the two groups separately.

\section{Group A.-The Macquarie Island Form.}

Masses of densely aggregated, small, brown, horny tubes set side by side horizontally, with the free ends curving away from the main axis, were obtained from rock scrapings, and from the under-side of stones at low water, at the North end of the Island. The free end of the tube is thinner and has sand grains adherent to it.

The contained worm, removed from one such tube, has a total length of $35 \mathrm{~mm}$., of which the gill-plume occupies about $5.6 \mathrm{~mm}$; the body is $2.5 \mathrm{~mm}$. in width, and contains 65 segments.

The gills are speckled with red-brown dots and splashes, closely set along the inner side of the filaments, the shaft being umpigmented. The filaments are loose and curl ontwards; I find 15-20 filaments on each side. There is no inter-filamentary membrane.

Eggs were attached to the gills, as has been stated by other writers. The thorax in these small forms contains usually 8 segments; though sometimes only 7.

\section{Group B.-Commonuealth Bay Forms.}

Of these I have seventy-two specimens, some still within their tubes, others have been removed therefrom before preservation.

The tubes are of tough parchment-like material of a yellow-brown colour; but those from greater depths, 110-120 fathoms, are more darkly coloured, and are rather olive-brown.

The longest tube measured came from 25 fathoms; it attains a length of $400 \mathrm{~mm}$. with a diameter of $8 \mathrm{~mm}$; the surface is smooth, the upper end thinner, flexible, and paler in tint. It has some sand grains adherent to it.

Another tube from the same hanl is much paler in tint, and much slenderer than the majority; measures $90 \mathrm{~mm}$. by $1.5 \mathrm{~mm}$.

Still another tube is $270 \mathrm{~mm}$. long, and contains a worm measuring $226 \mathrm{~mm}$. inclusive of the gills, which account for $44 \mathrm{~mm}$.

A worm of $150 \mathrm{~mm}$. exclusive of the gills, which are $40 \mathrm{~mm}$. long, contains 190 segments. Its breadth at the collar is $6 \mathrm{~mm}$; its greatest breadth is $8 \mathrm{~mm}$., and the height of the body $5 \mathrm{~mm}$.

I measured a number of these worms from various depths in order to see whether there was any correlation between size and depth, but I find none. 
The thoracic region presents a mucle wider range of variation as to the number of component segments than do those in Group $A$. Of those examined I find the following numbers :-

Six liave 8 segments.

One has 9 .

'Three have 10.

Three have 11 .

Five have 12.

Three have 12 on the right side and 13 on left.

One has 14.

'I'wo have 15.

One has 14 on the right side and 10 on the left.

There is no apparent relation between the length of body and that of thorax, for in three worms measuring $170 \mathrm{~mm}$. two have 8 thoracic segments, and one has 12 .

Eight segments occur, also, in a worm $135 \mathrm{~mm}$. long; 11 segments occur in a worm $195 \mathrm{~mm}$., while another of the same length has 14 segments.

In two smaller .worms of this group, measuring 72 and $85 \mathrm{~mm}$., I find that the thorax contains only 8 segments. It seems, then, in a very gencral way that the number of thoracic segments increases with the size, that is the age, of the individual.

The gills contain a much larger number of filaments than in the typical form of the species. Thus, there are thirty to forty filaments on each side; but in a worm $170 \mathrm{~mm}$. long, I find only twen'sy-one filaments.

The pigmentation of the gills is liable to much variation also. In some they are uniform in tint, or rather uncoloured; in others there are the usual irregularly arranged splashes of red-brown along their length. In one case I noted that some of the dorsal filaments are without pigment, though most of them have a band of brown extending from the tip to about quarter the length; or even further down in the more ventral filaments. A few of them have in addition a sliort transverse band about half-way down.

In another individual there are three fairly regularly disposed patches at quarter, half, and three-quarter of the length from the base upwards, while the apex is, as usual, uncoloured.

Others, again, have more numerous distinct bands up to eight in number. One of the smaller specimens has purplish pigment arranged in irregular dots at wide intervals apart along the filaments.

Probably, had onc only a few of these larger worms before one, a new species would have been warranted, but I prefer to leave these in the present species. 
Localities.-

Macquarie Island.

Commonwealth Bay, Boat Harbour-

Station B, 25 fathoms (forty).

Station 3, 157 fathoms (three).

Station 7, 60 fathoms (eight).

Station 8, 120 fathoms (nine).

Station 12, 110 fathoms (seven).

Distribution.-Magellan Strait (Kinberg); Fuegia, Uschuaia, South Georgia, Kaiser

Wilhelm II Land, Kerguelen, Sonth Victoria Land (Ehlers); Ile Booth Wandel (Gravier); Falklands Islands (Fauvel).

Remarks.-It is more than probable that the worm referred to as Sabella ceratodaula Sclımarda by Miss E. Pratt (1900) as occuring at the Falklands is this species.

\section{Family SERPULIDE.}

Genus Serpula Linnaeus, s.st. Philippi.

SerPUla vermicularis, var. Narconensis Baird.:

S. narconensis Baird (1864), Proc. Linn. Soc., London, vol. viii, p. 21, pl. II, figs. 7,8 (operculum).

S. narconensis McIntosh (1885), p. 516, pl. LTV, fig. 5; pl. LV, fig. 1; pl. XXXI a, fig. 23.

S. narconensis var. magellanica, McIntosh (1885), p. 518, pl. LV, fig. 2; pl. XXXI A, figs. $24,25$.

S. patagonica Grube (1877), p. 550.

S. vermicularis Ehlers (1897), p. 140 ; (1901), p. 219.

S. vermicularis var. narconensis Ehlers (1912), p. 31 ; (1913), p. 581.

S. vermicularis Gravier (1906), p. 62; (1911), p. 147, pl. XII, figs. 170-174.

Baird established his species on a single specimen obtaincd during the Ross Antarctic Expedition; it was withont a tube, and was characterised by its operculum. McIntosh (1876, p. 322) compared it with a specimen collected by the Venus Transit Expedition to Kerguelen, which, although it lacked the operculım, was in its tube. He satisfied himself that the two are identical.

In 1897 Ehlers placed Baird's species as a synonym for S. vermicularis, and suggested that McIntosh's var. margellanica should be inchuded. But in 1912 Ehlers makes it a distinct variety, the tubes of which, he showed, are linked on with the type by a number of intermediate forms, in some of which even the everted lip, upon the possession of which Baird founded his species, was lacking. 
Several of these characteristic tubes, some containing the animal, were obtained during the expedition of the "Aurora."

The narrow, white calcareous tubes have a diameter of $2.75 \mathrm{~mm}$., and the thickened everted lip is $4.5 \mathrm{~mm}$. across. Along the course of the tube are similar thickened lips at intervals, indicating periods of cessation of growth. The tubes are more or less undulating, or may be coiled, where they are attached to some object, such as a stone or shell.

\section{Localities.-}

Boat Harbour, Station B, 25 fathoms.

Commonwealth Bay-

Station 1, 354 fathoms.

Station 2, 318 fathoms.

Station 3, 120 fathoms.

Station 9, 240 fathoms.

Station 10, 325 fathoms.

Distribution.- "Ile Narcon in the Antarctic Ocean" (Baird), Kerguelen (Grube), Marion Island, Heard Island (McIntosh), Magellan Strait (McIntosh, Ehlers), Admiralty Sound, S. Victoria Land, K. Wilhelm II Land (Fhlers), South American Antarctic (Gravier).

\section{Genus SPIRORBIS Daudin. \\ SPIRORBIS NORDENSKJÖLDI Ehlers.}

Ehlers (1901), p. 223.

Ehlers (1908), p. 165.

Gravier (1911), p. 153, pl. XI, figs. 153, 154.

Gravier has pointed out that it is difficult to be certain as to the identification of this species, as Ehlers has given no figure of it. Hence it is with some hesitation that I attribute our specimens to this species; they agree with the accounts referred to above and with Gravier's figures.

\section{Localities.-}

Boat Harbour, 3-4 fathoms.

Commonwealth Bay, Station D, 45-50 fathoms.

Distribution.-Punta Delgada, Bouvet Island (Ehlers), Petermann (Gravier). 


\section{BIBLIOGRAPHY.}

Apstein (1890).-Zool. Jahresber, Abth. f. Syst., vol. v. (Not seen.)

Arwidsson (1888).--Stud. ub. die Fam. Glyeeridie und Goniadidæ. Bergens Museums Aarkog, XI.

" (1906). - Studien uber die skandinavisehen und arktischen Maldaniden. Upsala.

, (1911).-Die Maldaniden. Wiss. Ergebn. d. Schwedischen Sudpolar Expedition, 1901-1903, vol vi, lief 6.

Asнworth (1903)._-"The Anatomy of Arenicola assimilis and of a New Variety of the Speeies," Quart. Journ., Miero. Sei., vol. xlvi.

" (1912).-Catalogue of the Chrtopods in the British Museum, Part I. Arenieolidx.

Augener (1913,1914).-- Die Fama Südwest Australiens. Ed. iv, Polychæta errantia, 1913. Bd. v, PolyehxŁa sedentaria, 1914.

Bexнam (1909).--Report on the Polyehxta of the Subantaretie Islands of New Zealand. Christchurch.

" (1915).-Report on the Polyehæta. (Biol. Results of the Fishing Experiments earried on by the F.I.S. "Endeavour," 1909-1914, vol. iii). Sydney.

" (1916).-Report on the Polyehæta. (Biol. Results of the Fishing Experiments earried on by the F.I.S. "Endeavour," 1909-1914, Part II, vol. iv). Sydney.

Bonnier (1893).-Bull. Sei. de la Franee ct de la Belgique, vol. xxv.

Claparède and Metschnikoff (1869).-Zeit. f. Wiss. Zool., vol. xiv. (Not seen.)

Cuvier (1817).-La Règne Animal, Edit. 2, tome ii.

Ehlers (1897).-Hamburger magalhaenisehe Sammel-Reise. Polyehæten.

" (1901).-Die Polyehæten der Magell. $и$. Chilen. Strandes.

" (1904).-Neuseeland Anneliden. Naeh. d. K. Ges. d. Wiss. Anst., aus Göttingen, Bd. iii.

, (1907).-Neuseeland Anneliden. Nach. d. K. Ges. d. Wiss. Anst., aus Göttingen, Part ii, Bd. v.

" (1908).-Die Bodensässigen Anneliden aus dem Sanml. d. deutseh. Tiefsee Expedition (Valdivia) 1898-1899. Jena.

, (1912).-National Antaretic Expedition. Polychæta.

" (1913).-Die Polyehæten Sammlungen d. deutseh. Sud-Polar Expedition, 1901-1903, Bd. xiii, Zoologie. Berlin. 
Fauvel (1897).--Recherches sur les Ampharétiens. Bull. Sci. de la France et de la Belgique, vol. $\mathrm{xxx}$.

" (1916).-Annélides polychètes des îles Falkland. Arch. d. Zool. Exper., vol. lv.

" (1917).-Annélides polychètes de l'Australe meridionale. Arch. d. Zool. Expér., vol. lvi.

" (1919).-Annel. polych. de Madagascar. Arch. d. Zool. Expér., vol. Iviii.

Gravier (1906).-Annélides Polychètes. Expédition antáretique française (19031905).

" (1911).—Annélides Polychètes. Deuxieme expédition antarctique française (1908-1910).

Grube (1877).-Anneliden Ausbente S.MI.S. Gazelle. Monatsber. d. K. Akad. Wiss. Berlin.

" (1878).-Die Fam. Eunicea: 2nd Abth. Lumbriconereidea. Jahresber. d. Schles. Gesell. f. Vaterl. Kultur.

KinberG (1857).-Annulata. Kgl. Svenska Fregatten Engenies Resa, 1851-1853.

" (1864-1866).-Annulata nova, Ofversigt af K. Svenska Vet. Akad. Forhandl.

Ko Rschelt (1893).— “ Uber Ophryotrocha puerilis." Zcit. f. Wiss. Zool., vol. lvii.

Langerhans (1880).-Die Wurmfanna Madeiras. Zeit. f. Wiss. Zool., vol. xxxiii.

LEIPER (1908).-List of generic names of polychæt worms that have been preoccupied, etc. Ann. Mag. Nat. Hist. (ser. 8.), vol. ii, p. 468.

MaLMGRen (1865-1867). - Nordiska Hafs-annulater.

McIntosh (1876). - New Species of Annelida from Kerguelen Island. Ann. Mag. Nat. Hist. (ser. 4), vol. xvii.

». (1879).-Zoology of Kerguelen. Transit of Venus Expedition, 1874-75. Phil. Trrans., vol. clxviii.

" (1885).-Annelida Polychæta. Reports of "Challenger" Expedition, vol, xui. (1915).-Ann. Mag. Nat. Hist. (ser. 8), vol. xv.

Moore (1903).-Polychæta from the Coastal Slope of Japan and from Kamchatka. Proc. Acad. Nat. Sci. Philadelphia.

" (1909). - Polychætous Annelids from Monterey Bay, and San Diego, California. Proc. Acad. Nat. Sci. Philadelphia.

" (1911).- The Polychætous Annelids dredged by the U.S.S. "Albatross," off the Coast of S. California in 1 1 c04. III. Euphrosynidx to Goniadidx. Proc. Acad. Nat. Sci. Philadelphia.

Müller (1776).-Zoologica Danica Prodromus. (Not seen.)

Oersted (1843).-Grönland. Annulata Dorsibranchiata. (Not seen.) 
PiXell (1913).-Polychata of the fam. Serpulide and Sabellida coll. by the Scottish National Antarctic Exped. Trans. Roy. Soc., Edinburgh, vol. xlix.

Prate (1900).-A collection of Polychxta from the Falkland Islands. Mem. Manchester Phil, Soc., vol. 45.

Quatrefages (1865).- - Histoire naturelle des Annélés.

RAMsaY (1914).-Polychæta of the fam. Nereidæ, coll. by the Scottish National Antarctic Exped. Trans. Roy. Soc., Edinburgh, vol. 1.

Rosa (1908).- - Raccolte Planctoniche, vol. v. Tomopteridi.

Saint Joseph, De (1888).--Annel. polych. des côtes de Dinard. Ann. Sci. Nat. (Zool.), sér. 7, vol. v.

$$
\text { " (1895).-Loc. cit. (ser. 7), vol. xx. }
$$

Schmarda (1861).-Neue Wirbellose Thiere, vol. I, part ii.

Southern (1909)._- "Pelagic Phyllodocidx." Fisheries, Ireland, Scient. Investigations, 1908, iii.

" (1911).--The Alciopinæ, Tomopteridæ, etc., loc. cit., 1910, iii.

Studer (1878).-Arch. f. naturgesch, vol. xliv. (Not seen.)

Treadwell (1914).-Polychietous Annelids of the Pacific Coact, \&c. Univ. of Californa Publications. Zoology, vol. xiii.

WaIte (1916).-Australasian Antarctic Exped., 1911-1914, Scient. Reports, Fishes.

Wruley (1902).--Report on the coll. Natural History, "Southern Cross" expedition. Polychæta.

. " (1905).-Ceylon Pearl Fishery Report (Royal Soc.) "On the Polychæta.". 


\section{EXPLANATION OF PLATES.}

\section{Plate 5.}

Syllis closterobranchia (figs. 1-2).

Fig. 1. A parapod, anterior face $(\times 45)$.

2. The ends of two acicula.

\section{S. brachycola (fig. 3 ).}

Fig. 3. Tip of aciculum.

Spharosyllis mointoshi (figs. 4-6).

Fig. 4. Anterior end, dorsal view $(\times 45)$. Camera outline from a specimen mounted in glycerine.

5. Ventral view of the same $(\times 45)$.

6. The tips of acicula.

Autolytus charcoti (figs. 7-10).

Fig. 7. A transverse section of the body, atokous stage, in front of the middle (camera $\times 30$ ). The dorsal cirri present a series of glands along the upper part of the outer surface; the great ventral glandular pad is distinctly marked off from the body.

8. A chæta from the upper part of a bundle $(\times 720)$.

9. The "head" of Polybostrichus, ventral view (camera $\times 20$ ), showing the relative lengths of the appendages and the ventral swellings below the great lateral tentacles.

10. The "head" of Polybostrichus, dorsal view ( $\times 30$ ), showing the epaulettes of the species; some of the appendages cut short.

Exogone anomalochata (figs. 11-13).

Fig. 11. Anterior end, camera outline $(\times 90)$; the nuchal organ is seen on the left side.

12. Hind end ( $\times 90)$.

13. The three forms of chætxe in the dorsal bundle (enlarged: (a) Tip of the capilliform; $(b)$ end of the uppermost gomphotrich, side and fiont views; (c) one of the remainder of the bundle, both aspects.

\section{Hololepidella Aynni (figs. 14-20).}

Fig. 14. Dorsal view of the head $(x 10)$; the palp and peristomial cirri of the right side are omitted. On the left side the first elytrophore is indicated.

15. A parapod of a cirriferous segment, posterior face (camera $\times 15$ ). 
Fig. 16. A parapod from an elytriferous segment anterior face $(\times 15)$.

17. One of the ventral chretæ $(\times 90)$.

18. A ventral chæta from about the middle of the bundle $(\times 90)$.

19. The apex of a ventral chæta $(X 260)$. The pectinated frills are very delicate and have an irregular course.

20. The apex of a dorsal chæta $(\times 250)$.

\section{Plate 6.}

\section{Harmothoe spinosa (fig. 21).}

Fig. 21. Dorsal view of a portion of a specimen, showing a "chess-board" pattern. The parallel lines represent olive; the groups of dots, brown; where these are closer together, a dark brown. (Enlarged.)

H armothoe tuberosa (figs. 22-29).

Fig. 22. Tip of a dorsal chæta $(\times 360)$, showing the characteristic " bearded " nature of the upper frills, as seen in an unworn chæta. The hairs really lie more closely alongside the axis, bnt are here represented as outspread so as better to show their relations. The hairs from the lower bundles in the figure have been omitted from the near surface. The apparent "spines" are the edges of the frills composed of the bases of several hairs superposed.

23. Side view of the apex of a dorsal chæta from which the "hairs" have been worn away $(\times 360)$. The aspect as seen in Canada balsan mounts is likely to be misleading, as owing to the transparency of the frills in front of the axis, the structnre is scarcely visible; but in glycerine mounts it is more readily interpreted; the apparent spines along the edge are then seen to be the frills bending round the bristle, and are thus a measure of the height and thickness of these frills.

24. Portion of the shaft of the same dorsal chrta, immediately below the apex shown in fig. $23(\times 360)$. This shows the angular character of the shaft and the difference in the nature of the frills on face and side. The uppermost frills are confined to the front face, the lateral frills commence some distance from the apex.

25. A ventral chæta from about the middle of the bundle $(x 35)$.

26. A ventral chita from upper part of the bundle, the frilled region from the side, showing the spines in the upper frills $(\times 360)$.

27. The same from the front face $(X 360)$, showing two rows of spines one on each side.

28. Three posterior elytra of an individual with abnormally developed conical tubercles $(\times 6)$.

29. The last elytron of the same $(X i 0)$. 
Harmothoe abyssorum (figs. 30-35).

Fig. 30. View of the head $(\times 10)$.

31. Front view of the prostomium, showing the tips of the "peaks" and the relative position of insertion of the median and lateral tentaeles.

32. A eirriferous parapod (camera, $\times 10$ ).

33. A tubercle of an elytron, side and top views (enlarged).

34. A dorsal chæta $(\times 90)$.

35. A ventral chrta $(\times 90)$.

Eulagisca corrientis (figs. 36-38).

Fig. 36. The head dorsal view $(\times 5)$. The tentacles are broken off, the palps. are represented as having been cut away to a greater or less amount, and the subtentacular frontal cone $(f . c$.$) is seen below and projecting beyond the tenta-$ culophore. 'The peristomial parapod is produced into a fine point $(l)$ between the dorsal and ventral cirri.

37. View of the head from in front $(X 5)$, showing the position of the frontal cone. The three tentacles are seen to lie in the same plane. The peristomium is foreshortened, and only the apex of the lobe $(l)$ and insertion of the two cirri are indieated; $(l)$ elytrophore of second segment.

38. The second elytron $(\times 10)$.

\section{Plate 7.}

Eulagisca corrientis (figs. 39-42).

Fig. 39. The eleventh parapod, anterior face $\left(\times 2 \frac{1}{2}\right)$.

40. One of the upper dorsal chxtx $(\times 45)$.

41. A ventral chreta from the middle of the bundle $(X 45)$.

42. A ventral ehrta from the lower part of the bundle ( $\times 45)$.

\section{Hermaaion rouchi (figs. 43-47.)}

Fig. 43. One of the most dorsal chata from a large individual $(\times 45)$.

44. The apex of one of the smaller dorsal chrtæ from the upper part of a bundle, from one of the smaller individuals $(\times 250)$.

45. The apex of one of the largest dorsal chætæ, much worn $(\times 250)$.

46. One of the uppermost chrtx of a ventral bundle of a large individual $(X 45)$.

47. One of the lowermost ventral chatx of a large individual $(\times 45)$.

$$
\text { Eulalia hunteri (figs. 48-52). }
$$

Fig. 48. Anterior end of the worm $(\times 9)$.

49. The head ( $x$ 27). Only the appendages of the right side are completed.

50. A parapod, anterior faee (camera, $\times 20$ ).

51. A ehæta $(\times 250)$ : the appendix is not necessarily curved. The outline is too heavily drawn; it is in the object extremely fine. Note the peculiar articulation.

52. A gioup of pharyngcal papille $(\times 35)$; three are shown from above. 
Eulatia mcleani (figs. 53-57).

Fig. 53. Anterior end (enlarged).

54. A parapod $(\times 20)$.

55. A chrta $(\times 500)$, side view. The appendix is not necessarily curved.

56. The articulation of appendix $(\times 500)$.

57. Pharyngeal papillæ $(\times 70)$; the two broader ones are seen in a plane different from the rest. A top view of one is shown.

Pelagobia viguieri (figs. 59, 60).

Fig. 58. (There is no drawing corresponding to this number.)

59. The peristomial cirrus $(\times 90)$ showing the axial chitinous support.

60. A portion of the cirrus near the base $(\times 720)$, showing the tapering proximal termination of the axial supports, and the thickened cuticle on the posterior face of the cirrus.

\section{Plate 8.}

Vanadis antarctica (figs. 61-63).

Fig. 61. A complete chæta (camera, $\times 30$ ). It was drawn in two parts, a small bubble of air lay about half-way along, which enabled me to join the two sketches accurately together.

62. Two aspects of the articulation at different foci $(\times 360)$.

63. Another form of articulation less comınonly met with $(\times 360)$.

Tomopteris carpenteri (figs. 64-66).

Fig. 64. Head and first segment $(\times 10)$. The cirrus is cut short; its supporting chæta is shown as projecting a short distance beyond the cut end.

65. The head of a soft specimen $(\times 10)$, showing the epaulette of the left side triangular, as is figured by Quatrefages for the species.

66. A parapod $(\times 10)$.

\section{Nereis loxechini (figs. 67-75).}

Fig. 67. Head of a well-preserved specimen $(\times 10)$.

68. Head of soft specimen $(X 5)$.

69. A parapod of 20 th segment, ventral view $(\times 10),(a)$ anterior face, $(p)$ process of the posterior lip.

70. The 8th parapod in outline; anterior face $(\times 20)$.

71. The 34th parapod in outline; posterior face $(\times 20)$.

72. The 80th parapod in outline; posterior face $(\times 20)$.

73. One of the stout brown heterogomph falcigers, from the supra-acicular bundle $(\times 250)$.

74. Heterogomph falciger, from the sub-acicular bundle $(\times 250)$. 
Lumbriconereis macquariensis (figs. 76-81).

Fig. 76. Head, ventral view (enlarged).

77. The 8th parapod (camera, $\times 90)$.

78. A posterior parapod $(\times 90)$.

79. The only articulated hook which was found $(x 360)$; it occurred in an anterior parapod.

80. The usual form of hook, taken from the 25th parapod ( $\times 360)$, as seen from the side and from in front, showing the denticulated lower portion of the hood.

81. A capilliform chæta from 8th foot $(\times 250)$.

Spharodorum spissum (figs. 82-84).

Fig. 82. Entire animal drawn from the unstained cleared specimen (camera, $\times 20$ ).

83. Anterior end of the same $(\times 70)$ camera outline. The prepharyngeal region is shown in surface view, except the eye vesicles (?), but the pharynx is at a deeper level; the dark patches in front of it are glands; the bundles of chætæ lie really below the rest, on the ventral surface.

84. The posterior end $(\times 70)$, surface view.

\section{Plate 9.}

Spharodorum spissum (figs. 85-89).

Fig. 85. Portion of the surface of the stained specimen $(X 35)$, showing the ventral surface and a portion of the animal's right side. The outline is drawn under the camera; but details are filled in from various parts of the surface.

86. A portion of the margin of the same preparation $(\times 45)$, showing the absence of any definite alternation in size of the papillæ.

87. A papilla (magnified; freehand).

88. A parapod (magnified; freehand), seen from below. Note the thickness of the cuticle.

89. A chæta (magnified; freehand).

Aricia marginata var. moleani (fig. 90).

Fig. 90. One of the anterior neuropods with the additional series of spines behind and below the third row.

Scoloplos marsoni (figs. 91-94).

Fig. 91. The parapod from the 7 th segment $(\times 45)$.

92. Parapod from the 24th $(\times 45)$.

93. From the 32nd ( $X 45$ ).

94. From the 53rd seginent $(X 45)$.

$\cdot 83892-Q$ 
Leana arenilega (figs. 95, 96).

Fig. 95. Anterior end from above (enlarged); nost of the tentacles are omitted; a few are shown cut short.

96. Anterior end from below.

Scione mirabilis (figs. 97-100).

Fig. 97. Anterior end, from the side (enlarged), showing the contracted gill, as described for S. spinifera.

98. Anterior end of another specimen (a female) with gill extended, as in McIntosh's figure. This was removed from its tube in which it had been preserved.

99. Uncinus from a posterior segment $(\times 360)$.

100. Uncinus viewed from above: $(a)$ one of the upper ones; $(b)$ one of the lower ones.

Polycirrus hamiltoni (figs. 101-106).

Fig. 101. Ventral view of anterior end. Note the nephridial papiliæ below the notopods.

102. The 13th parapod, with contained eggs $(\times 90)$.

103. Notopodial capilliform chæta, with unsymmetrical flange $(\times 720)$.

104. Notopodial capilliform chæta, the slender denticulated form $(X 720)$.

105. Uncinus $(\times 720)$.

106. Uncinus from above (freehand) to show the "hood" above the teeth.

\section{Plate 10.}

Phyllocomus dibranchiata (figs. 107-123).

Fig. 107. Entire worm in outline; natural size.

108. The anterior end from in front (enlarged) - br., branchiferous segment; pe., peristomium ; $p r$., prostomial plate ; $x$., nuchal organ.

109. Anterior end from the right side. Letters as above.

110. Anterior end, dorsal view of left side $-g_{\text {e }}$ insertion of gill.

111. Transverse section of gill, showing axis and the four lamellæ.

112. Transverse section of a gill-folium $(\times 45)$. The blood-vessels cut through are indicated by the rows of black ovals.

113. Anterior end ventral view $-l$., group of pigment spots ; 3 ., the first chætigerous segment. Other letters as above.

114. Dorsal view of the junction of thorax $(t h$.$) , and abdomen (a b .1)(\times 8)$.

115. Posterior end, side view $(\times 5)$.

116. The tentacles displayed within the buccal cavity by slitting the body wall along the dotted lines shown in fig. 113-m., the membrane surrounding the base of the tentacles.

117. A portion of the peritentacular membrane with the tentacles turned forwards, showing the proximal and distal rows of pigment spots. 
Fig. 118. A dorsal chæta viewed in the plane with two flanges $(\times 45)$.

119. A dorsal chreta viewed in the plane at right angles to the above; it is now curved, and has one broader flange ( $X 45)$.

120. A portion of a dorsal chrta lying on its two-flanged side, with the third flange projecting upwards $(\times 720)$.

121. The tenth abdominal neuropod $(\times 20),-d$., distal process ; $p$., proximal papilla.

122. Neuropodial uncinus $(\times 360)$.

123. The same viewed from above.

Amythas membranifera (figs. 124-132).

Fig. 124. Anterior end dorsal view (natural size). The missing gills are indicated by the dotted lines.

125. Anterior end (enlarged) - $y$. , the anterior gill of right side; $g .2, y .3$, the gills, or their bases, of the second and third pairs ; $b r$. , branchiferous segment; pr., prostomium.

126. Side view of anterior region $(\times 2)$-pe., peristomium; other letters as above.

127. Anterior end, seen from in front $(\times 3)$, with the tentacular membrane $(t . m$. pressed downwards-l., lateral region of the lower lip (peristomium); $p r$, prostomium; s.o., supra-oral arch.

128. View from below of the anterior end, dissected from the left side, and the floor pressed down-gl., ventral gland shields; $l . a$. , lateral region of the supraoral arch ; i.l., inner lower lip or sphincter ; $u r p .$, neuropods ; pe., peristomium; t.m., tentacular membrane.

129. Side view of the abdominal segments.

130. Thoracic uncinus $(\times 360)$.

131. Abdominal uncinus $(\times 360)$.

132. Abdominal uncinus, viewed from above $(\times 360)$. 


\section{N IEX.}

\begin{tabular}{|c|c|c|c|c|c|c|c|c|c|c|c|}
\hline byssorum HARMOTHOE... & $\ldots$ & $\ldots$ & ... & $\ldots$ & $\ldots$ & $\ldots$ & $\cdots$ & $\ldots$ & $\ldots$ & $\ldots$ & $\ldots \quad 42$ \\
\hline byssorum Eunoa & $\ldots$ & $\ldots$ & $\ldots$ & $\ldots$ & $\cdots$ & $\ldots$ & $\cdots$ & $\cdots$ & $\ldots$ & $\ldots$ & $\ldots \quad 42$ \\
\hline affinis ARENICOLA assimilis & $\ldots$ & $\ldots$ & $\cdots$ & $\ldots$ & $\cdots$ & $\cdots$ & $\ldots$ & $\cdots$ & $\ldots$ & $\cdots$ & ... 108 \\
\hline LCIOPA & $\ldots$ & $\ldots$ & $\ldots$ & $\ldots$ & $\ldots$ & $\ldots$ & $\ldots$ & $\ldots$ & $\ldots$ & $\ldots$ & $\ldots 58$ \\
\hline cyonia Eurythoe ... & $\ldots$ & $\ldots$ & $\ldots$ & $\ldots$ & $\ldots$ & $\ldots$ & $\ldots$ & $\ldots$ & $\ldots$ & $\ldots$ & $\begin{array}{ll}\ldots & 69\end{array}$ \\
\hline ambiguum HeRMadION... ' & $\ldots$ & $\ldots$ & $\ldots$ & $\ldots$ & $\ldots$ & $\ldots$ & $\ldots$ & $\ldots$ & $\ldots$ & $\ldots$ & $\ldots 50$ \\
\hline AMPHARETE & $\cdots$ & $\cdots$ & $\cdots$ & $\cdots$ & $\ldots$ & $\ldots$ & $\cdots$ & $\ldots$ & $\ldots$ & $\cdots$ & ... 103 \\
\hline MPHITRITE & $\ldots$ & $\ldots$ & $\ldots$ & $\ldots$ & $\ldots$ & $\ldots$ & $\ldots$ & $\ldots$ & $\ldots$ & $\ldots$ & ... 82 \\
\hline AMYTHAS... $\quad \ldots-\ldots$ & $\ldots$ & $\ldots$ & $\cdots$ & $\cdots$ & $\ldots$ & $\ldots$ & $\therefore$ & $\ldots$ & $\ldots$ & $\ldots$ & ... 102 \\
\hline anomalochata Exogone & $\ldots$ & $\ldots$ & $\ldots$ & $\cdots$ & $\ldots$ & $\ldots$ & $\ldots$ & $\cdots$ & $\ldots$ & $\ldots$ & $\ldots 24$ \\
\hline intarctica Alciopa & $\ldots$ & $\cdots$ & $\cdots$ & $\cdots$ & $\ldots$ & $\ldots$ & $\ldots$ & $\ldots$ & $\cdots$ & $\ldots$ & $\ldots 58$ \\
\hline ntarctica EReutro _.. & ... & $\ldots$ & $\ldots$ & $\ldots$ & $\ldots$ & $\ldots$ & $\ldots$ & $\ldots$ & $\ldots$ & $\ldots$ & $\ldots 95$ \\
\hline antarctica LAGISCA & $\cdots$ & $\cdots$ & $\cdots$ & $\cdots$ & $\cdots$ & $\cdots$ & $\ldots$ & $\cdots$ & $\cdots$ & $\cdots$ & $\ldots \quad 35$ \\
\hline antarctica LAONOME ，.. & $\ldots$ & $\cdots$ & $\ldots$ & $\cdots$ & $\ldots$ & $\ldots$ & $\ldots$ & $\ldots$ & $\ldots$ & $\ldots$. & ... 109 \\
\hline aniarctica NEOTTIS & $\ldots$ & $\ldots$ & $\ldots$ & $\ldots$ & $\ldots$ & $\cdots$ & $\ldots$ & $\ldots$ & $\ldots$ & $\ldots$ & $\ldots 91$ \\
\hline nearctica Potamilla ... & $\cdots$ & $\cdots$ & $\cdots$ & $\cdots$ & $\cdots$ & $\cdots$ & $\cdots$ & $\cdots$ & $\cdots$ & $\cdots$ & ... 109 \\
\hline antarctica RHodine $\quad .$. & $\cdots$ & $\cdots$ & $\cdots$ & $\cdots$ & $\cdots$ & $\cdots$ & $\ldots$ & $\cdots$ & $\ldots$ & $\ldots$ & ... 105 \\
\hline antarctica VANAdIS $\quad \ldots$ & $\ldots$ & $\cdots$ & $\ldots$ & $\ldots$ & $\ldots$ & $\cdots$ & $\ldots$ & $\ldots$ & $\cdots$ & $\cdots$ & $\ldots 58$ \\
\hline antarcticus Thelepus ... & $\cdots$ & $\cdots$ & $\cdots$ & $\cdots$ & $\cdots$ & $\cdots$ & $\cdots$ & $\cdots$ & $\therefore$ & $\ldots$ & ... 91 \\
\hline RENICOLA $\quad \ldots \quad \ldots$ & $\ldots$ & $\ldots$ & $\cdots$ & $\cdots$ & $\cdots$ & $\cdots$ & $\cdots$ & $\cdots$ & $\cdots$ & $\cdots$ & ... 108 \\
\hline irenilega LEANA.. & $\ldots$ & $\ldots$ & $\ldots$ & $\ldots$ & $\ldots$ & $\ldots$ & $\ldots$ & $\ldots$ & $\ldots$ & $\cdots$ & ... 89 \\
\hline Aricia $\quad \ldots \quad \ldots$ & $\cdots$ & $\ldots$ & $\ldots$ & $\ldots$ & $\ldots$ & $\ldots$ & $\ldots$ & $\ldots$ & $\ldots$ & $\cdots$ & $\ldots 77$ \\
\hline Imiger SCOLOPLOS & $\cdots$ & $\cdots$ & $\cdots$ & $\cdots$ & $\cdots$ & $\cdots$ & $\cdots$ & $\cdots$ & $\cdots$ & $\cdots$ & $\ldots 80$ \\
\hline ssimilis ArEnicola ... & $\cdots$ & $\cdots$ & $\ldots$ & $\ldots$ & $\cdots$ & $\cdots$ & $\cdots$ & $\ldots$ & $\cdots$ & $\ldots$ & $\ldots 108$ \\
\hline ustralis NerEIS & $\ldots$ & $\ldots$ & $\ldots$ & $\ldots$ & $\ldots$ & $\cdots$ & $\ldots$ & $\ldots$ & $\ldots$ & $\ldots$ & $\ldots 67$ \\
\hline AUTOLYTUS & $\ldots$ & $\cdots$ & $\cdots$ & $\cdots$ & $\cdots$ & $\cdots$ & $\cdots$ & $\cdots$ & $\cdots$ & $\cdots$ & $\ldots \quad 27$ \\
\hline enthaliana LATMONICE prod & ducta & $\ldots$ & $\ldots$ & $\ldots$ & $\cdots$ & $\ldots$ & $\cdots$ & $\cdots$ & $\ldots$ & $\cdots$ & ... 31 \\
\hline rachycola SyLLIS & $\ldots$ & $\ldots$ & $\cdots$ & $\ldots$ & $\ldots$ & $\ldots$ & $\ldots$ & $\ldots$ & $\ldots$ & $\ldots$ & ... 22 \\
\hline branchiferus LEPIDONOTUS & $\cdots$ & $\cdots$ & $\cdots$ & $\cdots$ & $\cdots$ & $\cdots$ & $\cdots$ & $\cdots$ & $\cdots$ & $\cdots$ & $\ldots 40$ \\
\hline Hcvicirris LUMBRICONEREIS & $\cdots$ & $\cdots$ & $\cdots$ & $\cdots$ & $\cdots$ & $\cdots$ & $\cdots$ & $\cdots$ & $\cdots$ & $\cdots$ & $\ldots 72$ \\
\hline capitata GLYCERA & $\ldots$ & $\ldots$ & $\ldots$ & $\ldots$ & $\ldots$ & $\ldots$ & $\ldots$ & $\ldots$ & $\ldots$ & $\ldots$ & ... 74 \\
\hline carpenteri TOMOPTERIS... & $\ldots$ & ... & $\ldots$ & $\ldots$ & ... & $\cdots$ & $\ldots$ & $\ldots$ & $\cdots$ & $\cdots$ & $\ldots 61$ \\
\hline charcoti Autolytus $\quad .$. & $\ldots$ & $\cdots$ & $\cdots$ & $\ldots$ & $\cdots$ & $\cdots$ & $\cdots$ & $\cdots$ & $\ldots$ & $\cdots$ & ... 27 \\
\hline charcoti Eulalia & $\cdots$ & $\cdots$ & ... & $\cdots$ & $\cdots$ & $\cdots$ & $\cdots$ & $\cdots$ & $\cdots$ & $\cdots$ & $\ldots \quad 52$ \\
\hline chitoniformis LEPIDONOTUS & $\cdots$ & $\ldots$ & ... & $\ldots$ & $\ldots$ & ... & .. & .. & ... & $\cdots$ & $\ldots 40$ \\
\hline incinnatus THELEPUS ... & $\ldots$ & $\ldots$ & ... & $\ldots$ & ... & ... & $\because \cdot$ & $\cdots$ & $\cdots$ & $\cdots$ & ... 92 \\
\hline
\end{tabular}


Cirratulus

cirratus Cirratulus

claparedi OрHRYotrocha

clavalor ExogONE

closterobranchia SYLLIS...

commensalis Hololepidella..

comosa "Pionosýlis" .

complanala EURYThò...

corrichtis Eulagisca ..

crocca Phyllocomus ..

crosetensis LAGISCA

PACER.

dibranchiata Phyllcomus

dioranchiata PhYLlcomus

chlcrsi Terebella

ENIro

Ereutho...

eschcholtzi To iropteris...

Eteone ..

Eulagisca

Eulalia ..

Eunice .

EUNOA" ".

Eurytüó

Exogone...

Flabelitigera .

flynni Hololépidella.. fulgida Promenia

fullo HARMothó spinosa fullo Poirno: ...

gibber Autolytus gigantea Trypanosyllis Glycera...

hamiltoni Polycirrús ...

HaRióthoe

Hermäion

Heteronereis

heterosetosa Exogone..

Holol EPIDELLA... hunteri Eulaía

insignis Polycirrus . intermedia Rhodine. IsocIRRus JSOMASTUS 
japonica LUMRRICONEREIS jeffreysii LAGisca

jucunda Pronenia

kerguelensis AMPHITRITE kerguclensis ER EUtho ..

kerguclensis GLYCERA ...

kerguelensis Hermadiow

kerguelensis LuMBRICONEREIS...

kerguelensis Nereis

kerguelensis Polycirrus

kerguelensis Salvatoria

kerguelensis Scoloplos...

$\begin{array}{lllllll}\text { L_ETMONICE } & \ldots & \ldots & \ldots & \ldots & \ldots & \ldots\end{array}$

LAAGISCA $\ldots \quad \ldots \quad \ldots \quad \ldots$

lagiscoides, Harмothoe spinosa

LAONOME...

LEENA

LEPREA ..

longicirrata Pelagobia...

longicirratum HERMADION

loveni RhodrNe...

loxechini NereIs

LUMBRICONEREIS

maclearanus AUtolytus

macquariensis LUMBRICONEREIS

macrura NEPHTHYS

madeirensis PhyLLODOCE

magalhcensis Eulatia ...

magalhansis Hermadion

magalhansis LUMBRICONEREIS

magalhansis Platynereis

magellanica LAGISCA

magellanica Serpula

marginata ArICIA

mawsoni ScoLoplos

mcintoshi SPHEROSYLLIS

mcintoshi THeLEPUS

mcleani ARICIA marginata

mcleani Eulatia

medipapillala PHYLLODOCE

mombranifera AмYтHAS

microphylla Euladia ..

minimus Staurocephalus

minitum SPH ERODORUM

mirabilis ScIone 
molluscum HERMADION... mundata Flabelitgera

mutabilis Paractius

NAINEREIS

narconensis Serpula ...

NeotTis spectabilis

Nephthys

Nereis ...

Nicolea ...

nordenskjoldi SPIRORBIS

notialis Paractrus

notocera SyLLIS ..

ohlini Artcia

OPHROYOTROCHA

pacifica Eurythoe

Paractius

parvum SPHeRODORUM

patagonica $\mathrm{H}_{\mathrm{ARMOTHOE}}$

paucibranchiatus Physalmonotus

Pelagobia

perarmatus Isomastus ...

Phenacia

Phyllocomus .

Phyllodoce ...

Physalidonotus

Ph Yzelia

Pronosyluis

Platynereis ...

Polybostrichus

Polycrrrus

Polymana

Potamilla

producta Letmonice ..

Promesia

Pterautolytus...

Pterocirrus

puerilis OpHryotrocha

pycnobranchiala Eunice

reyi Eteone ...

rhombigera Exipo

Rhodine...

richardi TRYPANOSYLLIS

rouchi Hermadion

rugosus Physalidonotus 


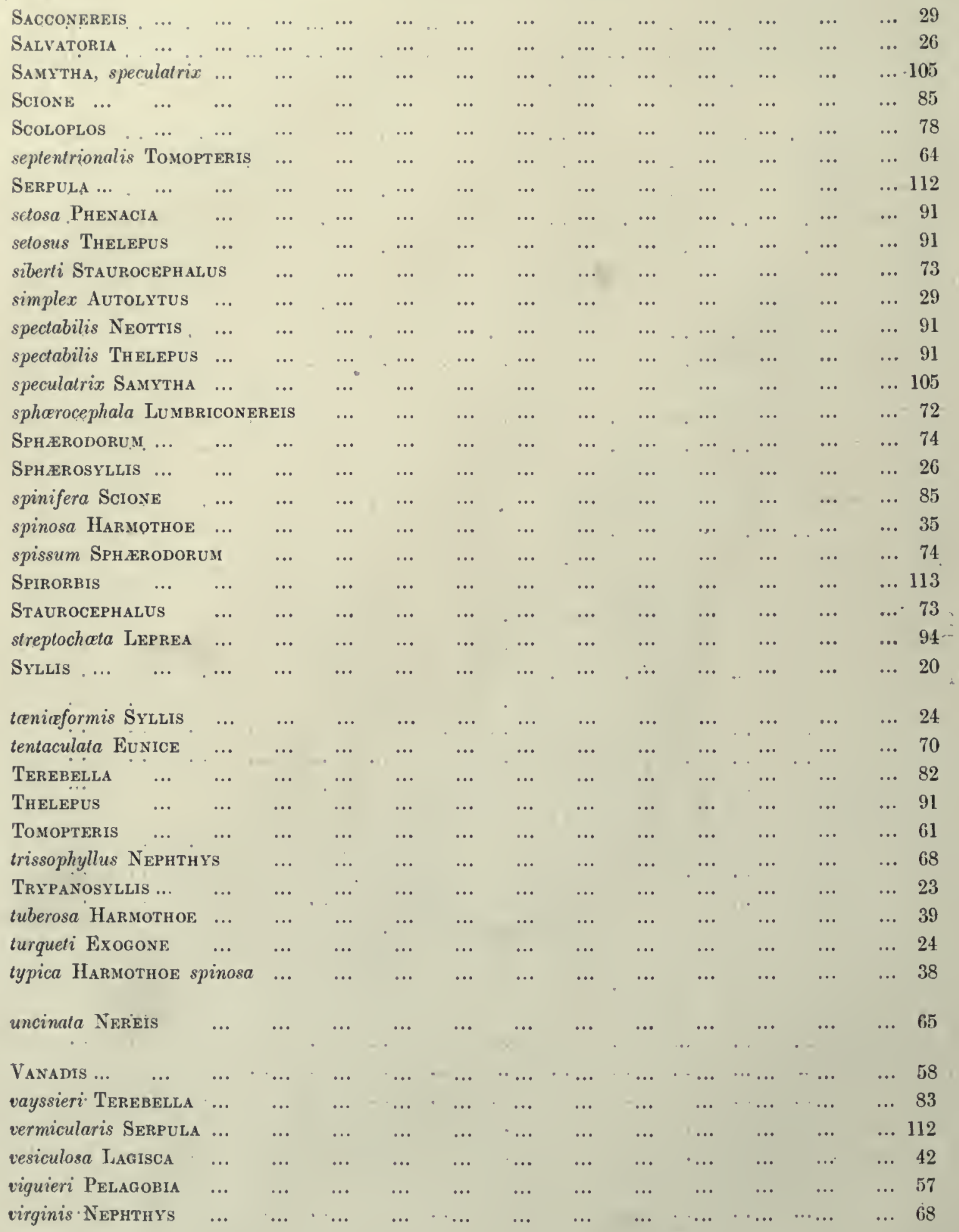

$\begin{array}{llllllllllllllll}\text { yungi IsoctrRus } & \ldots & \ldots & \ldots & \ldots & \ldots & \ldots & \ldots & \ldots & \ldots & \ldots & \ldots & \ldots & \ldots & \ldots & \ldots\end{array}$ 


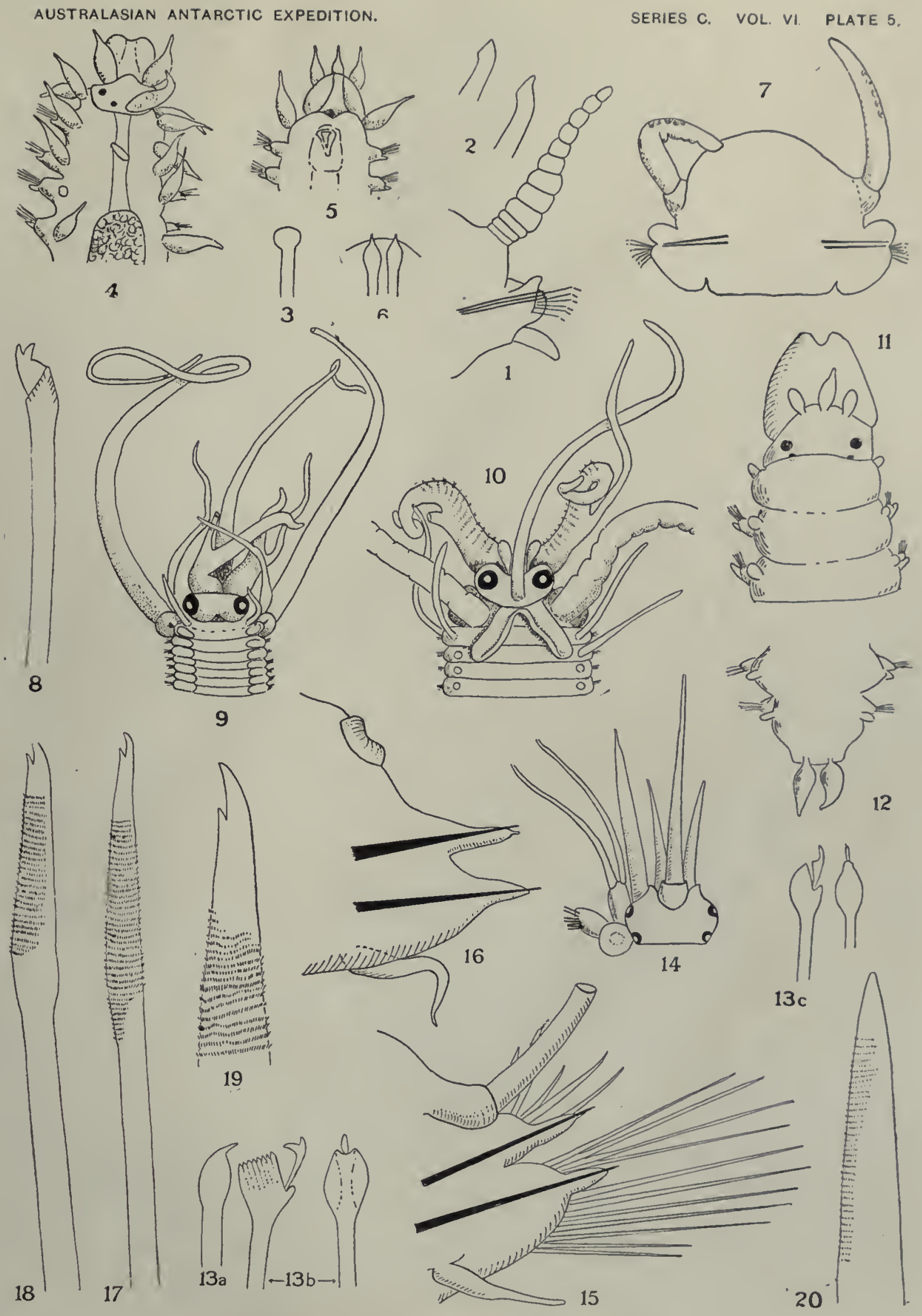





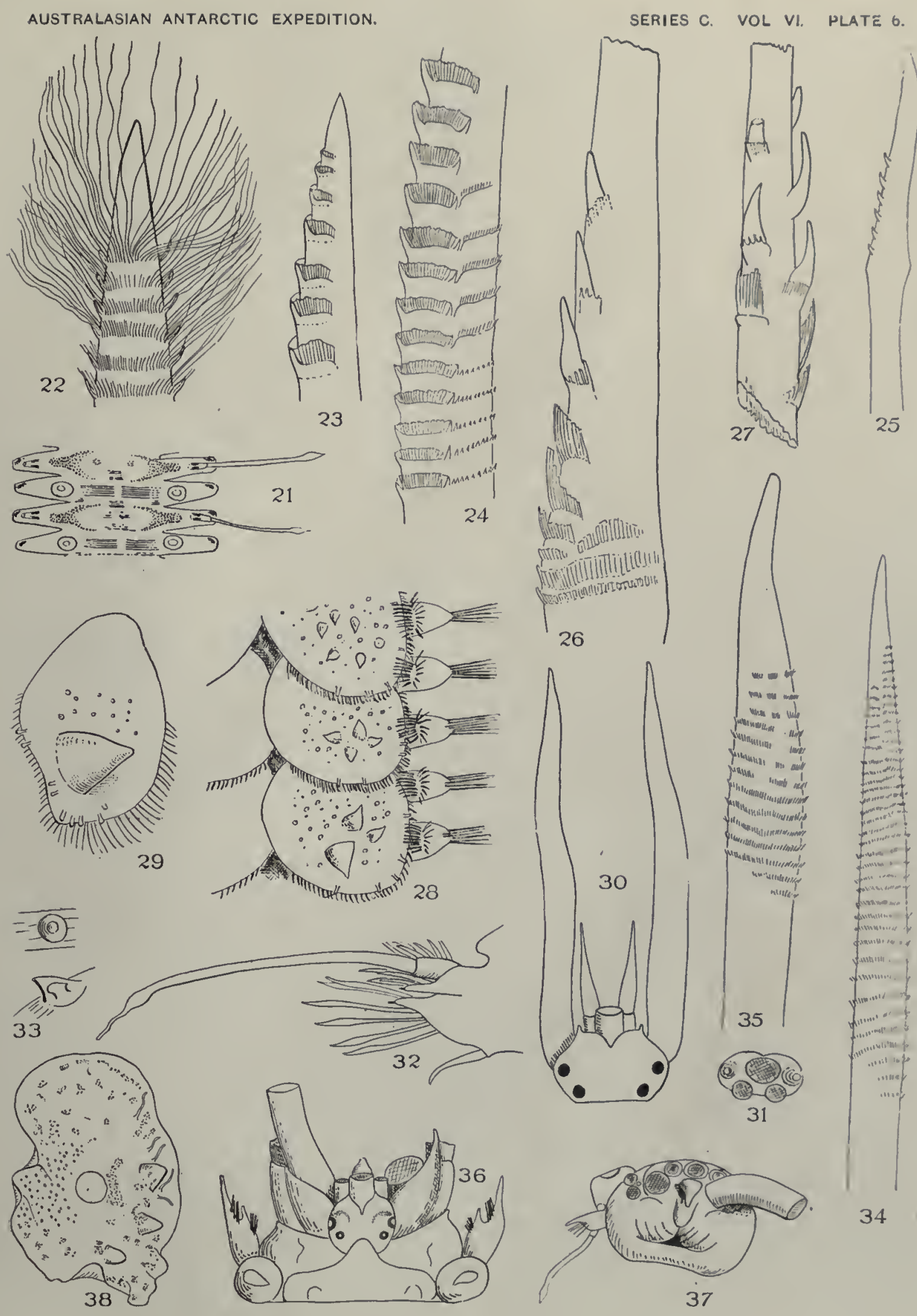



AUSTRALASIAN ANTARCTIC EXPEDITION.
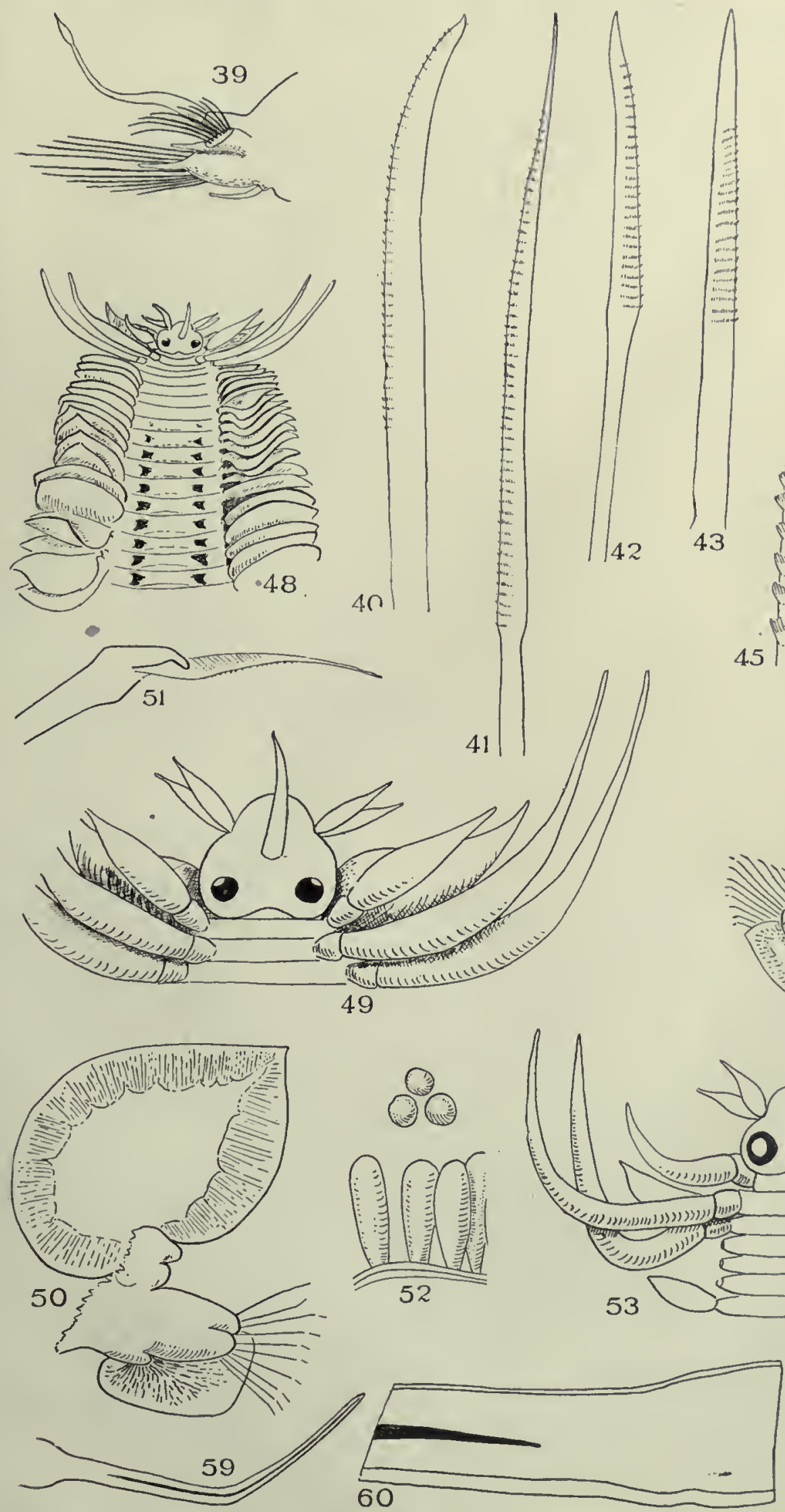

SERIES C. VOL. VI. PLATE 7.
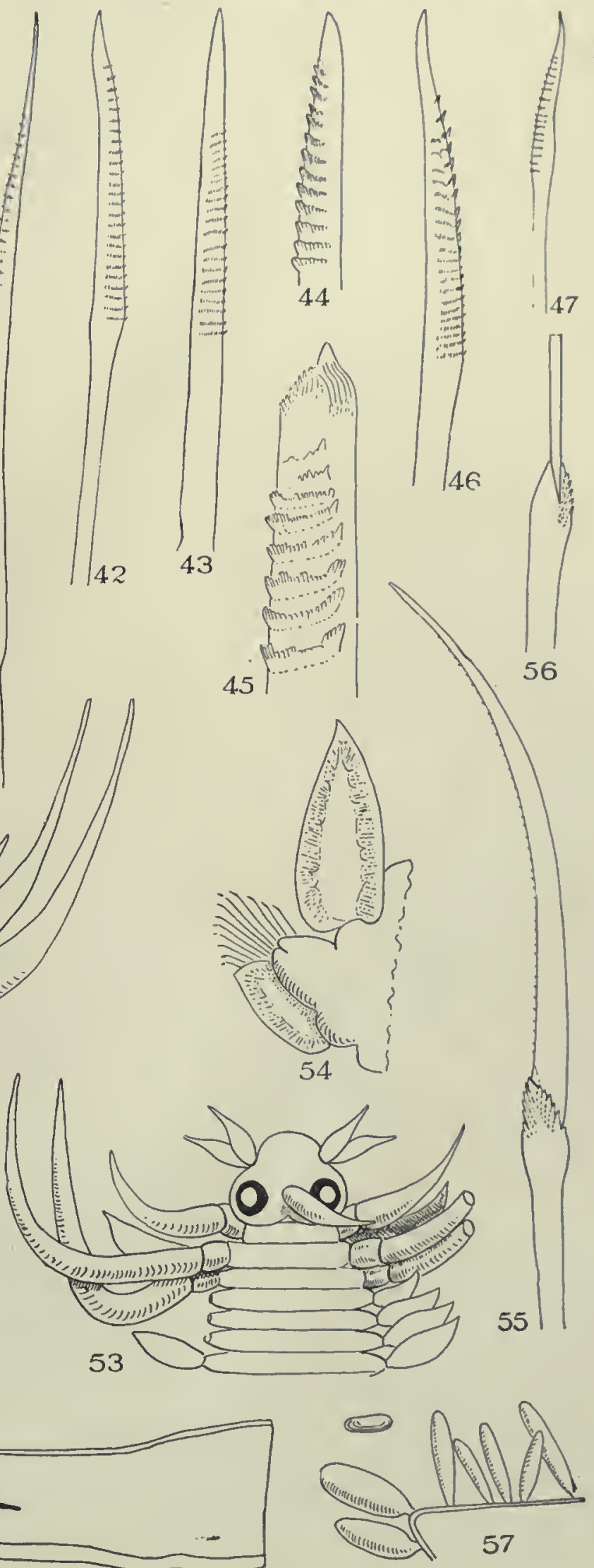

AUSTRALASIAN ANTARCTIC EXPEDITION.

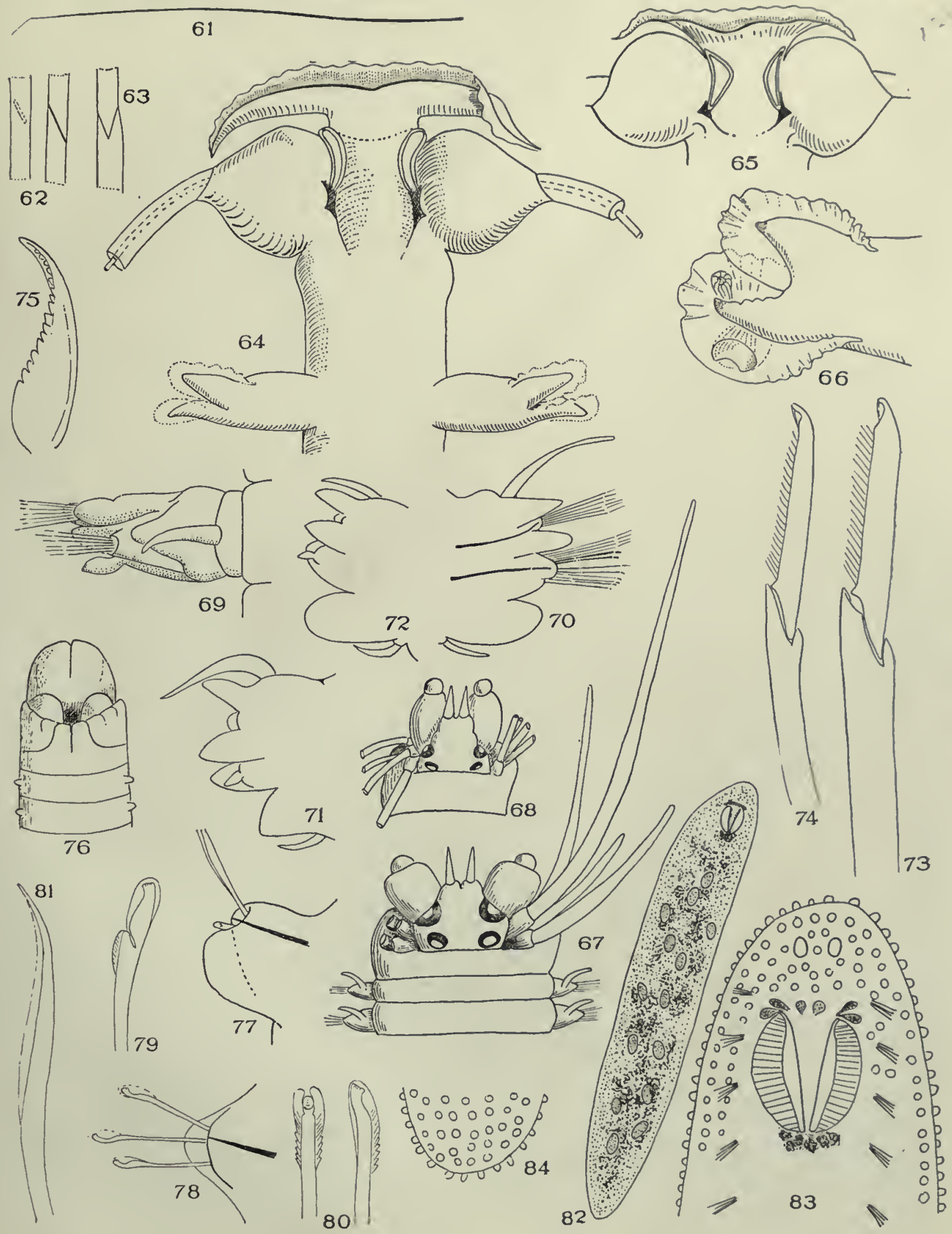



AUSTRALASIAN ANTARCTIC EXPEDITION.
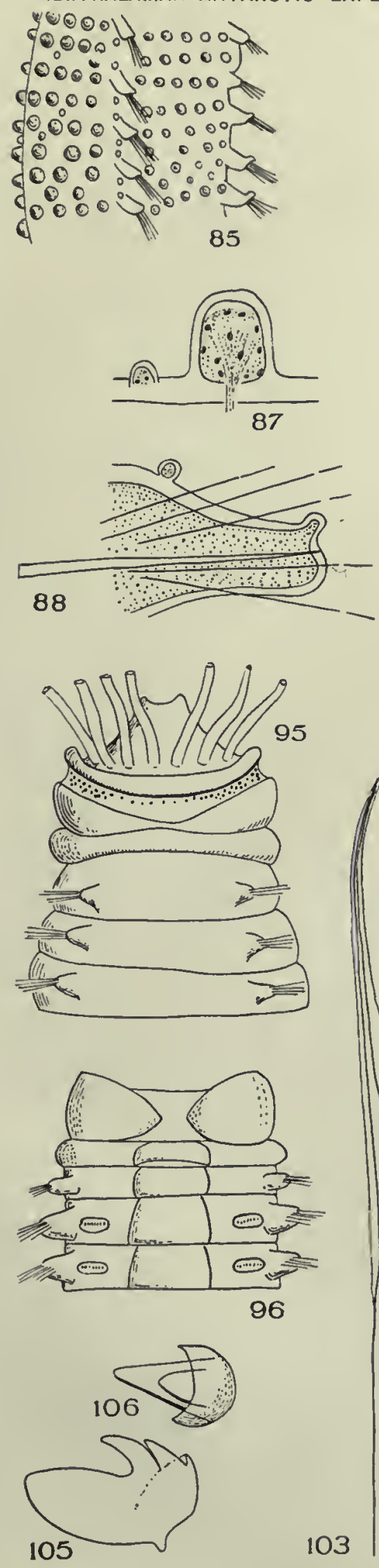
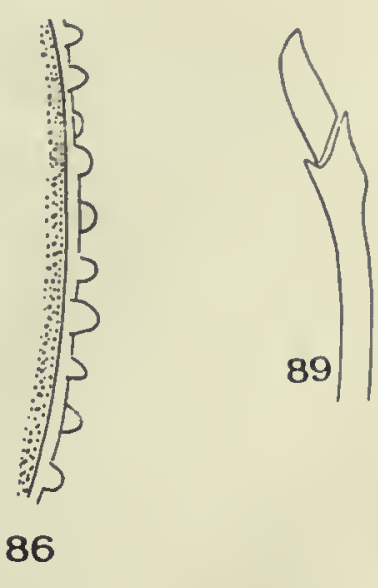

SERIES C. VOL. VI. PLATE 9

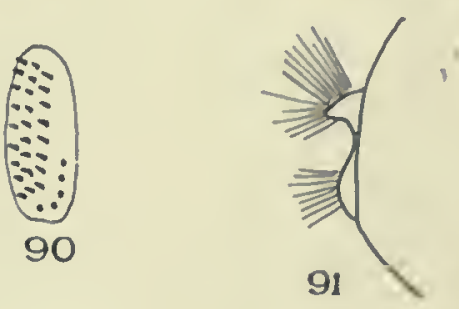

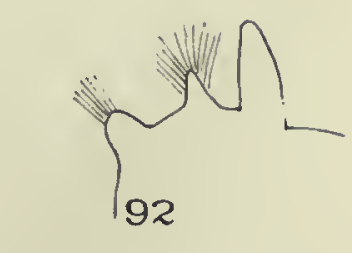
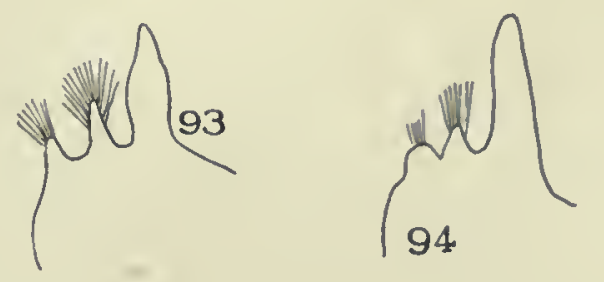


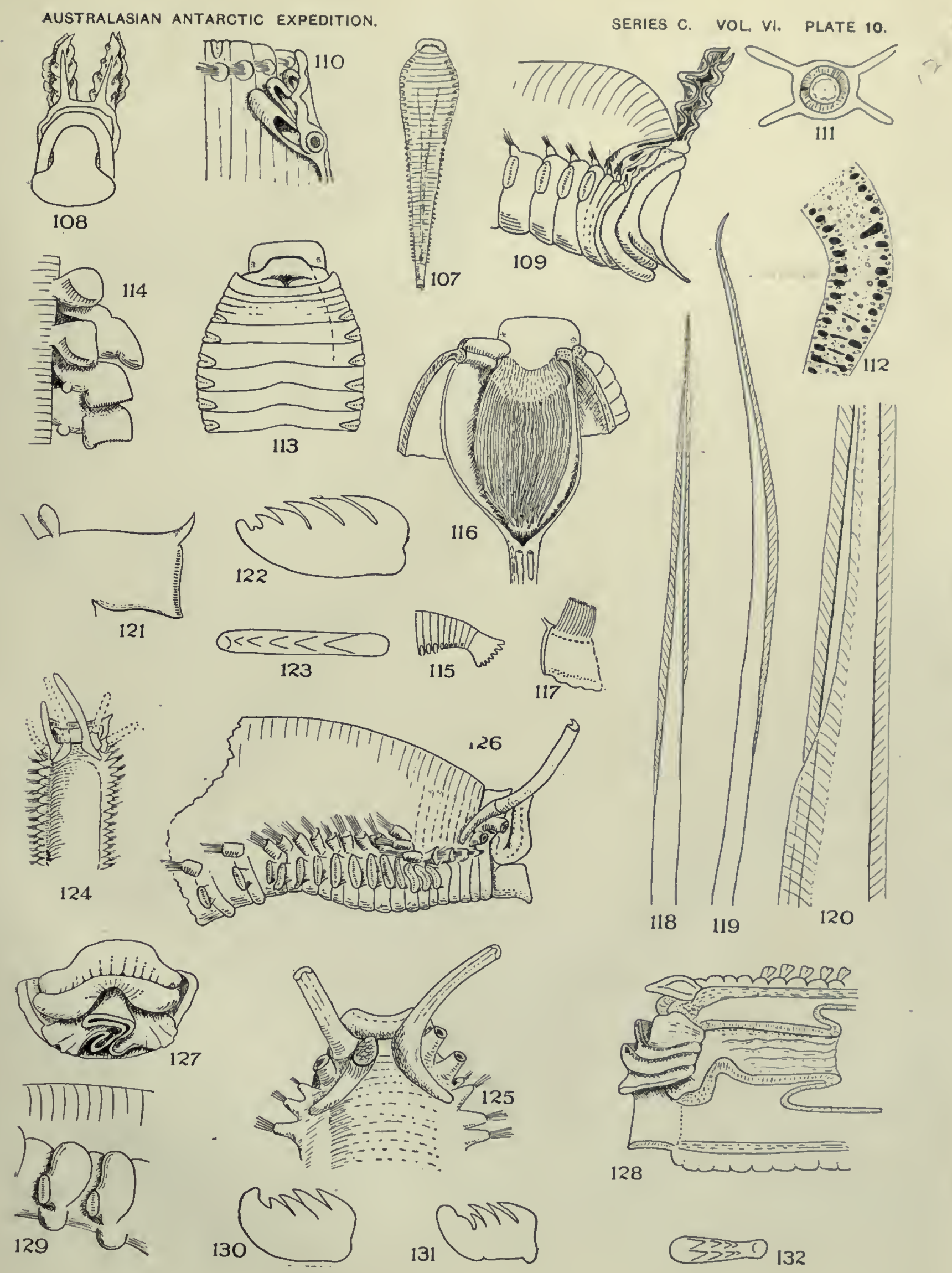






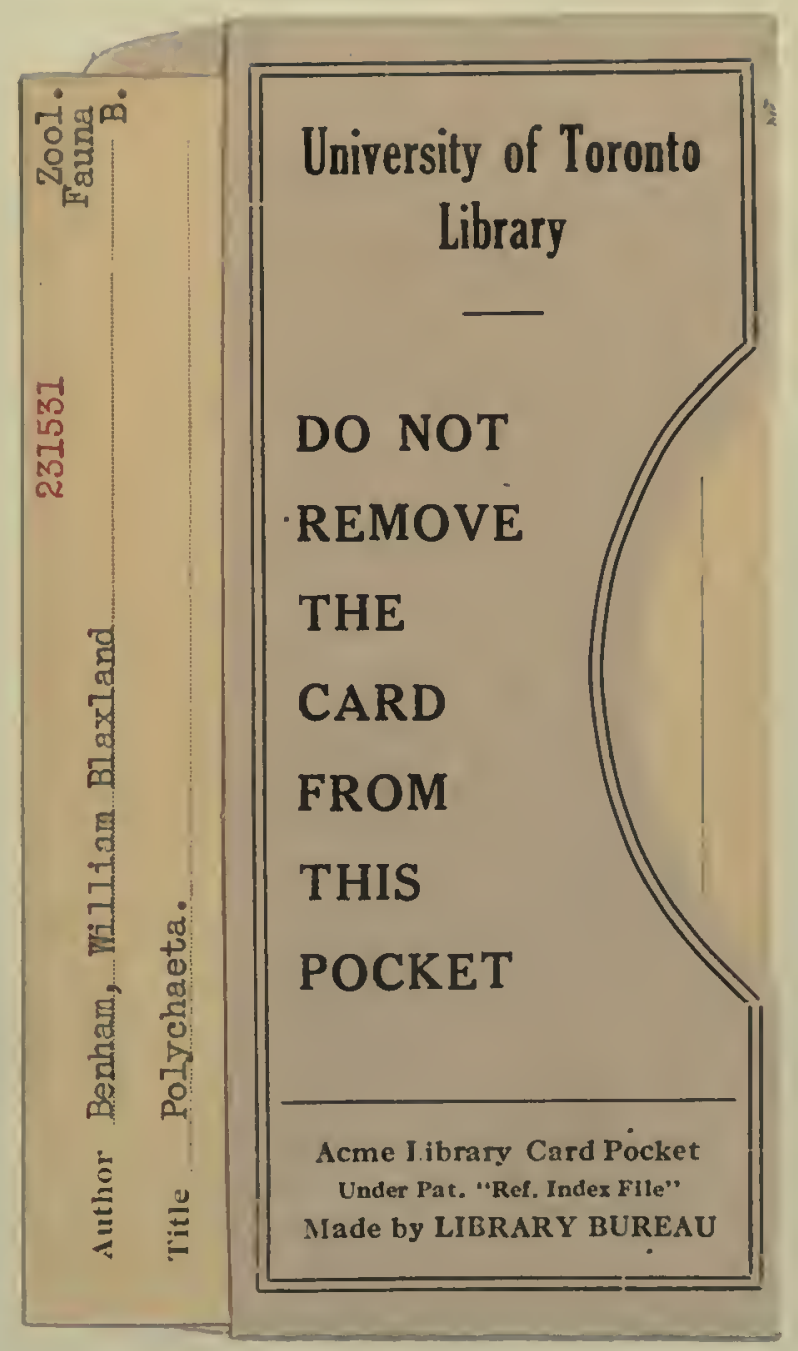


